\title{
INSIDE THE BOX: PHOTOGRAPHY AND THE PORTFOLIO FORMAT
}

by

Molly Kalkstein

Master of Fine Arts, Concordia University, Montréal, QC 2005

Bachelor of Arts, Swarthmore College, Swarthmore, PA, 2001

\begin{abstract}
A thesis
presented to Ryerson University

in partial fulfillment of the

requirements for the degree of

Master of Arts

in the Program of
\end{abstract}

Photographic Preservation and Collections Management

Toronto, Ontario, Canada, 2013 @ Molly Kalkstein 2013 


\section{AUTHOR'S DECLARATION FOR ELECTRONIC SUBMISSION OF A THESIS}

I hereby declare that I am the sole author of this thesis. This is a true copy of the thesis, including any required final revisions, as accepted by my examiners.

I authorize Ryerson University to lend this thesis to other institutions or individuals for the purpose of scholarly research.

Molly Kalkstein

I further authorize Ryerson University to reproduce this thesis by photocopying or by other means, in total or in part, at the request of other institutions or individuals for the purpose of scholarly research.

Molly Kalkstein

I understand that my thesis may be made electronically available to the public. 
Inside the Box: Photography and the Portfolio Format

Molly Kalkstein

Master of Arts in Photographic Preservation and Collections Management Ryerson University, 2013

\section{ABSTRACT}

Photography portfolios—-published sets of loose photographs housed in a folder or box-have been produced continuously since at least the 1850s, but have rarely received serious critical attention as a distinct format.

This thesis focuses on mid-twentieth-century limited edition portfolios and argues that they were informed by, and have contributed to, developments in photography more broadly. It provides a historical survey of the photography portfolio; considers its material, expressive, and commercial qualities, particularly in comparison to the photography book; and presents five case studies comprising eight portfolios produced between 1940 and 1972: Paul Strand's Photographs of Mexico (1940) and The Mexican Portfolio (1967); Ansel Adams's Portfolio One (1948); Berenice Abbott's 20 Photographs by Eugène Atget 1856-1927 (1956); Lee Friedlander and Jim Dine's Photographs \& Etchings (1969); and Les Krims's The Deerslayers, The Little People of America 1971, and The Incredible Case of the Stack O'Wheats Murders (1972). 


\section{ACKNOWLEDGEMENTS}

I must thank first and foremost my advisor and first reader David Harris, without whose enthusiasm, wide-ranging knowledge and curiosity, and fine eye for detail, this project would have been but a shadow of itself, had it existed at all. Thanks are also due to the generosity and expertise of the following people, who were instrumental in making this an alive and exciting process:

Leslie K. Brown, Britt Salvesen (Curator of Photography and Prints and Drawings, Los Angeles County Museum of Art), Jess Mackta, Jill Quasha, and Julia Van Haaften were all kind enough to provide me access to their own meticulous and enormously valuable research and writing.

Andrew Eskind and Jessica McDonald (Chief Curator of Photography, Harry Ransom Center) went above and beyond as my eyes in the field, continually turning up new resources on portfolios.

A. D. Coleman, Ann Thomas and Lori Pauli (Curator and Associate Curator of Photography at the National Gallery of Canada, respectively), and Sophie Hackett (Associate Curator of Photography, Art Gallery of Ontario, and my hawk-eyed second reader) spoke to or corresponded with me on a number of occasions, sharing their extensive professional experience and insight into this topic.

Leslie Squyres (Archivist and Head of Research Services, Center for Creative Photography) proved an invaluable aid in mining the archives at the CCP for a wealth of unpublished material on portfolios and the photographers who made them.

Les Krims was incredibly forthcoming and generous with his time, granting me the kind of first-person insight into his work that I could never have found elsewhere.

I would finally like to thank the Canadian Centre for Architecture, George Eastman House, the Metropolitan Museum of Art, the National Gallery of Canada, and the Ryerson Image Centre for allowing me access to their collections over the course of my research. 


\section{TABLE OF CONTENTS}

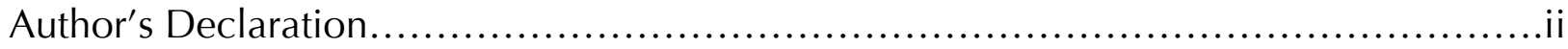

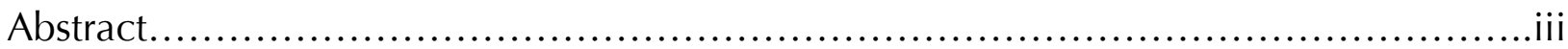

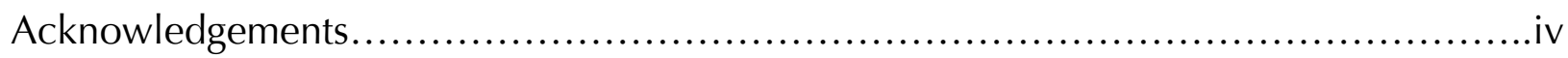

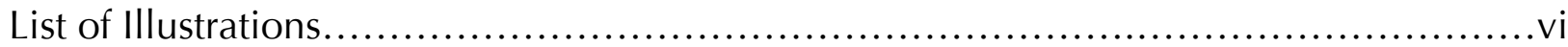

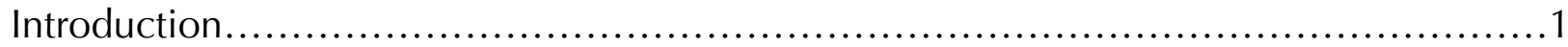

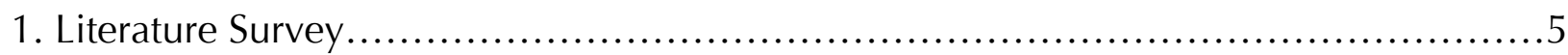

2. A Brief History of the Photography Portfolio............................................. 11

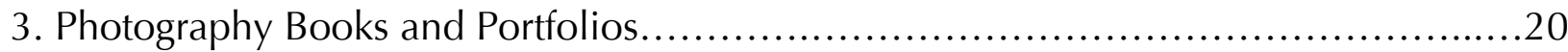

4. Case Studies of Selected Twentieth-Century Portfolios..................................30

4.1 Paul Strand: Photographs of Mexico (1940) and The Mexican Portfolio

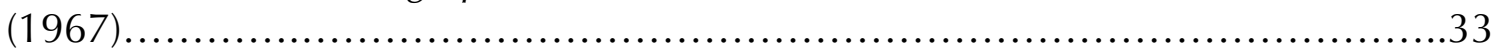

4.2 Ansel Adams: Portfolio One (1948) .........................................47

4.3 Berenice Abbott: 20 Photographs by Eugène Atget 1856-1927 (1956)...........54

4.4 Lee Friedlander and Jim Dine: Photographs \& Etchings (1969)..................64

4.5 Les Krims: The Deerslayers, The Little People of America 1971, and The Incredible Case of the Stack O'Wheats Murders (1972)............................69

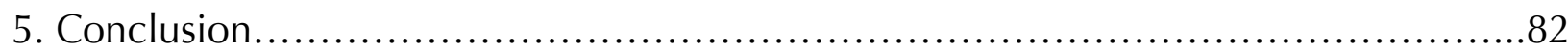

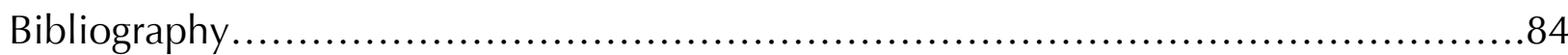




\section{LIST OF ILLUSTRATIONS}

1. Paul Strand: Photographs of Mexico (1940) and The Mexican Portfolio

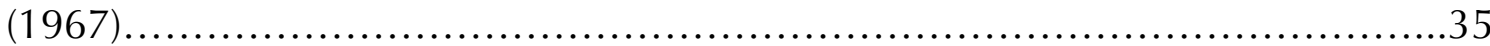

Illustrations include portfolio cover and twenty photogravures, of Photographs of Mexico only.

2. Ansel Adams: Portfolio One (1948).

Illustrations include portfolio cover, text folio cover, and twelve gelatin silver prints. (Not included in the electronic version of this thesis.)

3. Berenice Abbott: 20 Photographs by Eugène Atget 1856-1927 (1956)...................56 Illustrations include portfolio cover, text folio cover, and twenty gelatin silver prints.

4. Lee Friedlander and Jim Dine: Photographs \& Etchings (1969).

Illustrations include preface sheet, colophon, and sixteen sheets each containing one gelatin silver print and one etching. (Not included in the electronic version of this thesis.)

5. Les Krims: The Deerslayers, The Little People of America 1971, and The Incredible Case of the Stack O'Wheats Murders (1972).............................70 Illustrations include portfolio covers, introduction sheets, and 23, 24, and 10 offsetprinted photographs, respectively. 


\section{Introduction}

Since photography was introduced in the nineteenth century, photographs have been primarily presented and understood not as isolated images, but in groups and sets. ${ }^{1}$ From William Henry Fox Talbot's (1800-1877) The Pencil of Nature (1844-46) onward, photographs have been selected, assembled, and published to illustrate and distill complex ideas—scientific, architectural, documentary, artistic, or otherwise-more completely than any single image would be able to do alone. Groups of photographs have been compiled and disseminated through a number of physical formats, including handmade albums and mass-produced publications, as well as the curated collections of original prints that appear on exhibition walls. Among these formats is the photography portfolio.

The Oxford English Dictionary defines portfolio as a folder or case for holding individual works on paper, such as prints or maps, while an additional usage-which first appeared a century later-applies the term directly to the group of works so contained. ${ }^{2}$ By extension, a photography portfolio is a collection of loose photographs gathered in an enclosure of some kind. The history of the photography portfolio stretches back to the nineteenth century, when, taking a cue from portfolios of more traditional prints such as etchings and engravings, the format was used alongside albums and books to compile and distribute groups of images, most frequently architectural or travel views, or reproductions

\footnotetext{
${ }^{1}$ The Oxford English Dictionary (OED) defines a group as "an assemblage of persons, animals, or material things, standing near together, so as to form a collective unity," adding, "In early use the word often conveys a notion of confused aggregation, which in recent use is not implied." A set, meanwhile, is defined as "a number of things grouped together according to a system of classification or conceived as forming a whole." The key difference, then, seems to be one of origins: a group can be any miscellaneous assemblage of things unified by virtue of proximity, whereas the components of a set inherently belong to the same category, or were produced as parts of a whole. Thus any group of photographs might be selected to make up a portfolio, and this selection process, as made by explicit by the unifying framework of the enclosure, will make of them a set. Some portfolios, however, will also be seen to contain a set of photographs allied by more inherent characteristics as well_an artist's extended exploration of a given subject or theme, for example. ${ }^{2}$ The OED dates the earliest use of the term to 1713, as Porto Folio. Its first use to indicate the actual selection of compiled art works appears in 1813 , by then written simply as portfolio.
} 
of works of art. ${ }^{3}$ In many cases, the images contained in such portfolios were bound later at the discretion of the purchaser. In the twentieth century, however, photography portfolios began to take on a life of their own, developing into a distinctive mode of presenting groups of photographs, and specifically groups of photographs issued in editions. For the purpose of this thesis, I am restricting my discussion to published, limited edition photography portfolios, presented in cases or boxes—usually purpose-made-and often accompanied by an explanatory text. In the majority of instances, photography portfolios contain original photographic prints, but I will also be dealing with examples that contain photomechanical reproductions, such as photogravures. Because I am specifically looking at limited edition examples, I will furthermore be focusing on portfolios produced in the twentieth century, when editioning first took hold as a photographic art practice. $^{4}$

At the present time, the photography portfolio remains a much overlooked and undervalued entity in the history of photography. As demonstrated in my literature survey, the photography portfolio has rarely been written about as a specific, definable format, and what writing does exist focuses almost exclusively on the proliferation of portfolios as a vehicle for selling photographs in the burgeoning photography market of the 1970 s. Meanwhile, photographically illustrated books-a related but distinct mode of organizing and presenting photographs-have received more attention, particularly in recent years. Furthermore, photography books have been increasingly recognized as possessing inherent historical significance and artistic merit as a way for photographers to not only disseminate but also to interpret and enrich discrete bodies of work and conceptual

\footnotetext{
${ }^{3}$ See Anthony Hamber, "Facsimile, Scholarship, and Commerce: Aspects of the Photographically Illustrated Art Book (1839-1880)," in Art and the Early Photographic Album, ed. Stephen Bann (Washington DC: National Gallery of Art, 2011): 127 and 133.

${ }^{4} \mathrm{I}$ am referring here to the practice of creating limited editions, in which an artist or photographer promises to produce only a specific number of copies of a given work. Typically, these copies are numbered, a practice that, in photography, began in the twentieth century, and remained relatively rare until the 1960s and 1970s. The history of creating limited editions is somewhat longer in more traditional forms of printmaking, apparently beginning with the so-called etching revival in Great Britain. One early example of a signed limited edition of etchings, a version of Grey's Elegy published by the Etching Club, appeared in 1847, but the practice remained scarce until the 1880s. See Emma Chambers, "Objects of Desire: Etching and Print Collecting," in An Indolent and Blundering Art?: The Etching Revival and the Redefinition of Etching in England (Brookfield, VT: Ashgate, 1999), 63-87.
} 
projects. I will argue that the photography portfolio has a similar significance and merit in addition to (though never entirely separate from) its more workaday marketing function. For this reason, my thesis will be concerned specifically with portfolios conceived and created by individual photographers, rather than those produced-especially posthumously - by third parties such as galleries, a common practice particularly from the 1970s onward.

After the literature survey, which follows this introduction, my thesis is divided into three main sections. First, I sketch out a brief historical overview of the photography portfolio; a comprehensive timeline of the format remains absent from the literature to date, and my own overview remains necessarily provisional, given the limited scope of this paper. Second, I turn to writing about photography books to suggest a kind of formal and historical family tree for the photography portfolio, and a means by which they can be understood as distinctive photographic objects. Finally, in order to further explore some of the specific characteristics of this format, I provide an in-depth examination of eight portfolios: Photographs of Mexico (1940) and its reprint, The Mexican Portfolio (1967), by Paul Strand (1890-1976); Portfolio One (1948) by Ansel Adams (1902-1984); 20 Photographs by Eugène Atget, 1856-1927 (1956) printed by Berenice Abbott (18981991); Photographs \& Etchings (1969) by Lee Friedlander (b. 1934) and Jim Dine (b. 1935); The Deerslayers, The Little People of America 1971, and The Incredible Case of the Stack O’Wheats Murders (all 1972) by Les Krims (b. 1942).

My selections date from the 1940s through the early 1970s, and will thus highlight some of the ways that the format has been used in the mid-twentieth century-particularly prior to its meteoric rise in popularity as a marketing tool-as well as demonstrate that the portfolio has been employed by photographers in ways that reflect its particular physical characteristics and expressive potential. Given the enormous number of extant portfolios from the nineteenth century through the present day, my selection of eight objects is clearly limited and will do no more than scratch the surface. However, I believe that this selection raises a number of central issues in terms of how portfolios have been used by photographers during a crucial period in the development of the medium. Through this paper, I aim to lay the groundwork for further study of this neglected format, and to 
demonstrate ways that it has played an important, if often overlooked, role in the history of photography. 


\section{Literature Survey}

There exists at the present time little serious or sustained academic consideration of the historical, cultural, and artistic dimensions of the photography portfolio. While the format itself has been used by photographers since the mid-nineteenth century, the scant writing that does exist about portfolios usually links this format inextricably with the collection of and financial investment in photography, especially during the photography boom of the 1970s.

Lee Witkin (1935-1984), gallerist and publisher of limited-edition photography portfolios, and writer Barbara London's 1979 book The Photograph Collector's Guide is one of only a few published sources that pay specific attention to photography portfolios. The book itself is true to its title, having been published in the midst of the photography boom that began in the 1970s, for the purpose of providing collectors with a detailed overview on photography. The chapter on portfolios is, accordingly, primarily concerned with portfolios as collectibles. Witkin traces the rise of the photography portfolio to the early 1970s, "concurrent with the rising general interest in collecting photographic works," and suggests that among portfolios' more attractive attributes is the fact that they "can be split up for display, for single-print sales, or for the sake of joint owners." ${ }^{5}$ The chapter also includes discussions of editioning and resale value, but perhaps its most valuable component is an extensive list of historical and contemporary photography portfolios. ${ }^{6}$ Other guides to collecting photographs likewise make reference to limitededition portfolios, including Landt and Lisl Dennis's Collecting Photographs: A Guide to the New Art Book (1977), Richard Blodgett's Photographs: A Collector's Guide (1979), and Glen Warner's Building a Print Collection: A Guide to Buying Original Prints and

\footnotetext{
${ }^{5}$ Lee D. Witkin and Barbara London, "Limited-Edition Portfolios," in The Photograph Collector's Guide (Boston: New York Graphic Society, 1979), 277.

${ }^{6}$ Extensive but not comprehensive, especially as Witkin states explicitly that he is listing only original print portfolios, omitting those containing photomechanical reproductions. All told, the chapter lists nearly two hundred portfolios from the 1920 s onward, more than $85 \%$ of which were produced in the 1970 s.
} 
Photographs (1981). ${ }^{7}$ In each instance, the authors discuss photography portfolios in much the same way, considering them primarily as vehicles for selling prints, and focusing on their collectibility in a market context, in conjunction with the practice of creating limited editions.

In 2005, photography critic A. D. Coleman published "Limited-Edition Photography Portfolios" in Art on Paper. Supported by the perspective of three intervening decades, Coleman's discussion of portfolios continues to emphasize the portfolio format almost entirely as an outcome of the commercial photographic market that emerged in the 1970s. He does, however, suggest finally that some portfolios have a "substantial, artistic raison d'être," and that such portfolios "warrant study," the only such published assertion that I have encountered. ${ }^{8}$

The most focused considerations of photography portfolios, in fact, have not appeared in published texts, but rather in a few exhibitions scattered over the past four decades. ${ }^{9}$ New Portfolios, organized by the Galleries of the Claremont Colleges, showcased nine portfolios published in 1976, the year of the exhibition. The Portfolio as Object, mounted at the Center for Creative Photography (ССР) in 1981, traced the development of the photography portfolio in the twentieth century, using ten examples from the CCP's collection. Boxed Sets: Portfolios of the Seventies, also shown at the CCP in 2005, included twenty-eight portfolios from the Center's collection and sketched out a lineage for the portfolio in the early decades of the century, but, as per its title, honed in especially on the proliferation of the format in the 1970s. Finally, in 2009, Out of the Box: Portfolios from the Permanent Collection, curated by Leslie K. Brown at the deCordova

\footnotetext{
${ }^{7}$ Landt and Lisl Dennis, Collecting Photographs: A Guide to the New Art Boom (New York: E. P. Dutton, 1977), 107-110 and 175-183; Richard Blodgett, "The Pros and Cons of Limited-Edition Portfolios," in Photographs: A Collector's Guide (New York: Ballantine Books, 1979), 121-124; Glen Warner, Building a Print Collection: A Guide to Buying Original Prints and Photographs (Toronto: Van Nostrand Reinhold, 1981; Second edition: Toronto: Key Porter, 1984), 110-111 and 150-155.

${ }^{8}$ A. D. Coleman, "Limited-Edition Photography Portfolios," Art on Paper 9, no. 3 (January/February 2005): 45.

${ }^{9}$ I have drawn this information from unpublished material such as wall texts and checklists obtained from the institutions at which these exhibitions were held. Citations for the documentation from the four exhibitions listed here are found in the bibliography. In addition, the Photography Database (http://photographydatabase.org/) currently includes some thirty-two past exhibitions with titles containing the word portfolio, most of which are dedicated to one or two individual portfolios, rather than to the format itself. Thanks are due to Andrew Eskind for pointing me to this resource.
} 
Sculpture Park and Museum, focused on eleven portfolios from 1979 to 2006. Of these four exhibitions, only New Portfolios was accompanied by a catalog, quite modest in scale and scope, with a short framing essay by curator and photographer Leland Rice, a checklist of the included portfolios, and a highly selective and abbreviated list of additional portfolios published up to $1970 .{ }^{10}$ These four exhibitions are tantalizing indicators that the significance of the portfolio in photographic history has not gone entirely unremarked, but due to the lack of published documentation and the inherently ephemeral nature of exhibitions in general, a substantial exploration of the format has yet to be undertaken and, furthermore, made widely accessible.

Photographically illustrated books, on the other hand, have been a source of increasing scholarly interest since the 1970s and 1980s, with such academics, curators, and dealers as Lucien Goldschmidt and Weston Naef, Beaumont Newhall, Van Deren Coke, and Alex Sweetman producing texts on the subject. ${ }^{11}$ In more recent years, this interest has proliferated considerably, as evidenced by a veritable tide of surveys on the topic, including the lavishly illustrated two-volume set The Photobook: A History (volume 1 appeared in 2004, and volume 2 in 2008), compiled and written by curator and critic Gerry Badger and photographer and book collector Martin Parr. An important aspect of this and other recent writing on photography books is the emphasis on the multifaceted nature of on such works, in which the synthesis of elements such as sequencing, text, graphic design, and printing enhance the impact and meaning of the photographs themselves. ${ }^{12}$ In their introduction to The Photobook: A History, volume 1, Badger and Parr opine that one of the chief criteria for a noteworthy photography book is that it possesses a cohesive thematic quality. ${ }^{13}$ They make a case for books as portable, democratic, and more temporally permanent than traditional gallery or museum

\footnotetext{
${ }^{10}$ Leland Rice, New Portfolios (Claremont, CA: The Galleries of the Claremont Colleges, 1976).

${ }^{11}$ Van Deren Coke, Photographs, Photographically Illustrated Books and Albums in the UNM Libraries, 1843-1933 (Albuquerque, NM: Art Museum, University of New Mexico, 1977); Lucien Goldschmidt and Weston Naef, The Truthful Lens: A Survey of the Photographically Illustrated Book, 1844-1914 (New York: The Grolier Club, 1980); Beaumont Newhall, Photography and the Book, The Eighth Bromsen Lecture (Boston: Boston Public Library, 1983); Alex Sweetman, "Photographic Book to Photobookwork: 140 Years of Photography in Publication," California Museum of Photography Bulletin 5, no. 2 (1986): 1-32.

${ }^{12}$ Martin Parr and Gerry Badger, The Photobook: A History, vol. I (London: Phaidon, 2004), 7.

${ }^{13}$ Ibid., 8.
} 
exhibitions, and, in seeking to explain the omission of photography books from most general histories of photography, the authors suggest that these objects occupy a singular space between traditionally exhibited fine prints, and mass media such as magazines and newspapers. ${ }^{14}$

Similar and related arguments had also appeared earlier in a number of other sources on photographically illustrated books, including A. D. Coleman's pioneering 1981 article, "Some Notes on the Photography Book." Coleman praises in particular those photography-based books "intended to be dealt with as unified ideas, organic wholes whose components may be thematically linked or serially joined through narrative form or other structures." ${ }^{15}$ He goes on to write that such books require focused attention and thought, and posits that they are better suited to contemporary photography than "the original-print form we've come to value so highly," citing in particular the relative inaccessibility of fine prints to the general public. ${ }^{16}$ Two years earlier, Thomas Dugan introduced Photography Between Covers: Interviews with Photo-Bookmakers, published in 1979, with many of the same basic ideas, noting accessibility and the expressive possibilities of the photography book's sequential form, and in particular stressing the quality he describes as being "more than the sum of its parts." ${ }^{17}$ Many of the points made by these authors, including Badger and Parr, on the subject of photographically illustrated books can be applied to a consideration of portfolios (which share several of the same physical and conceptual characteristics), and can be used to highlight the ways in which portfolios are a distinct format in their own right; the different effects that being literally bound or unbound has on a group of photographs, for example. Writers such as Kim Sichel (in her 1989 article "On Reading Photographic Books") and Alan Trachtenberg (in his 1979 article "Walker Evans's Message from the Interior: A Reading," for example),

\footnotetext{
14 Ibid., 11.

${ }^{15}$ Coleman, A. D. "Some Notes on the Photography Book," in Tarnished Silver: After the Photo Boom (New York: Michmarch Arts Press, 1996), 115. First published in 1981.

${ }^{16} \mathrm{Ibid}$.

17 Thomas Dugan, Photography Between Covers: Interviews with Photo-Bookmakers (Rochester, NY: Light Impressions, 1979), 1.
} 
meanwhile, have suggested strategies for conducting close readings of photography books, paying particular attention to such key aspects as sequencing. ${ }^{18}$

In the case of portfolios, only a few specific examples have thus far been deemed significant enough in a photographer's oeuvre and career to warrant some consideration in published sources, to greater or lesser degrees. More often, portfolios are mentioned only in passing or are elided with photography books of the same or similar bodies of work. In many cases, however, portfolios are simply left out altogether.

Two examples of the first, relatively rare, case are Paul Strand's portfolio of Mexican photographs, and the portfolios produced by Ansel Adams. The recent Aperture publication Paul Strand in Mexico ${ }^{19}$ provides an extensive overview of the photographer's life and work in Mexico in 1932-34 and 1966, and includes a reprint of curator Katherine Ware's 1990 essay "Photographs of Mexico, 1940,"20 which focuses specifically on Strand's portfolio, published first as Photographs of Mexico in 1940, and again in 1967 under the title The Mexican Portfolio. Both Ware and historian James Krippner, who wrote Paul Strand in Mexico's main essay, examine Strand's decision to publish his work as a portfolio, and the physical and expressive qualities of the portfolio itself. The 1977 book The Portfolios of Ansel Adams is also notable for being devoted to the portfolios of a major photographer, reproducing not only the images contained in each of Adams's seven numbered portfolios, but their accompanying texts. ${ }^{21}$ At the same time, John Szarkowski's introduction pays little mind to the significance of the format itself, instead discussing Adams's work more generally.

\footnotetext{
${ }^{18}$ Kim Sichel, "On Reading Photographic Books," Views 10, no. 4 /11, no. 1 (Summer/Fall 1989), 3 and 22. Alan Trachtenberg, "Walker Evans's Message from the Interior: A Reading," October 11 (Winter, 1979): 529.

${ }^{19}$ James Krippner, Paul Strand in Mexico (México, D.F.: Fundación Televisa; New York: Aperture Foundation: Distributed by D.A.P., 2010).

${ }^{20}$ First published in Maren Stange, ed., Paul Strand: Essays on His Life and Work (New York: Aperture, 1990), 109-121, and based on Ware's earlier "Paul Strand: The Mexican Portfolio, 1940/1967," MA thesis (University of California, Berkeley, 1989).

${ }^{21}$ Ansel Adams, The Portfolios of Ansel Adams, introduction by John Szarkowski (Boston: Little, Brown, 1977).
} 
In his framing essay for Friedlander, a major publication by the Museum of Modern Art that accompanied the 2005 retrospective of Lee Friedlander's work, ${ }^{22}$ curator Peter Galassi repeatedly stresses the link between the photographer's work and his career-long interest in publishing that work in the form of photography books, citing again the notion of a whole producing a greater effect than its individual parts. Although Galassi does spend a few paragraphs discussing Friedlander's 1969 portfolio Photographs \& Etchings (made with the artist Jim Dine)—not only his first portfolio, but his first publication of any kind-it is his books that garner more sustained attention throughout the volume. Indeed, in other sources one sometimes finds mistaken reference to the portfolio as Work From the Same House, in fact the title of the Trigram Press book published simultaneously of the same body of work. ${ }^{23}$

Meanwhile, references to Les Krims' 1972 portfolios The Deerslayers, The Little People of America 1971, and The Incredible Case of the Stack O'Wheats Murders appear with some regularity, but to date there has not been a great deal of in-depth writing on Krims overall, and discussion of these portfolios has been limited primarily to a few contemporary journal articles and interviews. Even so, the portfolios produced by Strand, Adams, Friedlander, and Krims seem to have received significantly more consideration than those produced by most other photographers.

As demonstrated in this survey, photography portfolios have not gone entirely unremarked, but for the most part have escaped serious, sustained consideration. Information and speculation about them appears periodically, in isolated and often ephemeral pockets, and this thesis represents a first attempt to consolidate those instances and to sketch out an overview of the format's history. Further, given the dearth of substantial precedents on which to base an exploration of photography portfolios, it is clear that such a project must rest primarily on an examination of the objects themselves. I have therefore selected a small set of examples that suggest different avenues by which portfolios might be approached, different uses to which they have been put, and different historical moments and concerns that they represent.

\footnotetext{
${ }^{22}$ Peter Galassi, Friedlander (New York: The Museum of Modern Art, 2005).

${ }^{23}$ New Portfolios, Introduction and "Selected List of Photographic Portfolios."
} 


\section{A Brief History of the Photography Portfolio}

Rarely has the photography portfolio been singled out as a format possessed of its own individual significance, and yet its history is instructive in ways that belie the format's inconspicuousness. The forms and functions of the format have shifted in concert with photography's own evolution, offering a particular lens through which to view the larger history of the medium itself. The portfolio's derivation from an older fine arts tradition has served over the years to underscore a range of ideas and anxieties about the place of photography in the world of art as well as in the marketplace. It should be noted, however, that a fully researched history of the portfolio format has yet to be undertaken, and the following remains only a provisional outline.

In the nineteenth century, the portfolio-as I have defined it in my introductionwas especially fluid, overlapping with related apparatuses, such as albums and books, used to collect and distribute sets of photographic prints. In some cases, bound volumes were accompanied by portfolios of loose prints, such as Honoré d'Albert, duc de Luynes's (1802-1867) Voyage d'Exploration à la Mer Morte à Petra et sur la Rive Gauche du Jourdain, published in 1868-1874, whose three paper-bound volumes of text were supplemented by a pictorial atlas of 64 unbound photogravures, photographed by Louis Vignes (1831-1896) and printed by Charles Nègre (1820-1880). ${ }^{24}$ In other instances, bodies of work were produced, with some variation, both as books and as portfolios, as in Maxime du Camp's (1822-1894) publication Égypte, Nubie, Palestine et Syrie, produced in 1852, of which a few portfolios-containing 174 photographs, as opposed to the publication's 125-were also privately printed in 1849-1850 under the title Égypte, Nubie, Syrie: Paysages et Monuments. ${ }^{25}$

\footnotetext{
${ }^{24}$ A copy of this work resides in the collection of the Metropolitan Museum of Art, New York, accession number 2012.174.1-.4. Throughout this thesis, I indicate the location of copies of many of the portfolios I discuss. With one or two exceptions, however, I have only included this information when I have seen the portfolios in person or otherwise know them to be held at one or more of the institutions I visited over the course of my research.

${ }^{25}$ The Metropolitan Museum of Art also holds a copy of this portfolio, 2005.100.376.1-.174, thought to have been owned by the architect Eugène Viollet-le-Duc (1814-1879).
} 
Another recurring use of the portfolio combined commercial publishing enterprises with the format's long-standing private function as a housing for personally assembled collections of prints. In 1862, Francis Bedford (1816-1894) mounted an exhibition at London's German Gallery of 172 albumen prints of images taken during his four-month tour of the Middle East and North Africa as the official photographer to the Prince of Wales. Photography publishers Day \& Son produced a corresponding set of three portfolios, as well as an exhibition catalogue, both bearing the decidedly descriptive title Mr. Francis Bedford's Photographic Pictures Taken During the Tour in the East of His Royal Highness the Prince of Wales. ${ }^{26}$ The publishers' handlist and order form indicate that subscribers could choose to purchase the entire set of 172 photographs, divided into three sections (Egypt; The Holy Land and Syria; and Constantinople, The Mediterranean, Athens, $\& c$.$) , purchase these sections individually, or make their own selections of twenty$ photographs from the entire list. In each instance, the selections were housed in "handsome gilt-lettered Half-Morocco Portfolios." ${ }^{27}$ Similarly, when Eadweard Muybridge (1830-1904) announced his Animal Locomotion in 1887, subscribers had the option of making a selection of any one hundred collotypes ${ }^{28}$ from the total of 781 described in the prospectus, with each set of one hundred constituting "a Copy of the work," to be "enclosed in a Portfolio." ${ }^{29}$ Should a subscriber choose to purchase six copies (that is, a selection of 600 individual plates, enclosed in six portfolios), they were to receive the remaining 181 plates for free, for a total of eight portfolios. ${ }^{30}$ Animal Locomotion was also issued in its entirety as eleven bound volumes, with each volume comprising a specific category of images, such as Males (Nude) and Females (Semi-Nude). ${ }^{31}$

There also exist portfolios whose characteristics hew quite closely to those of more recent, familiar examples. To take one such case, in 1855, at the behest of the

\footnotetext{
${ }^{26}$ Sophie Gordon, Cairo to Constantinople: Francis Bedford's photographs of the Middle East, introduction by John McCarthy (London: Royal Collection, 2013), 46-48.

${ }^{27}$ Ibid., 46-48 and 242-243.

${ }^{28}$ In Muybridge's prospectus, the process is described as "reproduced from the original negatives by the photo-gelatine process of printing." See Eadweard Muybridge, Muybridge's Complete Human and Animal Locomotion, vol. 3 (New York: Dover, 1979), 1586.

${ }^{29} \mathrm{lbid}$.

${ }^{30}$ Ibid.

${ }^{31}$ See Parr and Badger, The Photobook, vol. 1, 52, which includes the list of all eleven volume titles.
} 
Government of India, Linnaeus Tripe (1822-1902) accompanied a British diplomatic mission as official photographer, and in 1857 produced fifty copies of a Burma Views portfolio, comprised of 120 mounted plates each. ${ }^{32}$ The prints were housed in a clothcovered four-flap case, accompanied by titles, explanatory captions, three architectural plans, and a signed and dated note in which Tripe described the contents of the portfolio and the working conditions under which the photographs were made. ${ }^{33}$ As Burma Views and the preceding examples suggest, portfolios in the nineteenth century were commonly produced of travel and architectural views, ${ }^{34}$ although Anthony Hamber, as cited in the introduction, also mentions portfolios of photographic reproductions of art. In the former cases, the portfolio format may have been selected for its suitability for representing complex spaces, structures, and the experience of travel through the assembly of multiple images, and for the ceremoniousness implied by the creation and presentation of a limited number of personalized objects. ${ }^{35}$ In the latter example-portfolios of art reproductionsthe unbound structure allowed purchasers to subsequently distribute the images across personal portfolios dedicated to the work of individual artists. ${ }^{36}$

Overall, however, it can be difficult to gauge the prevalance of portfolios from this era, partly due, no doubt, to the very lack of a binding that might have otherwise served to keep them intact, allowing many original portfolios to be broken up and dispersed, or

\footnotetext{
32 Janet Dewan, The Photographs of Linnaeus Tripe: A Catalogue Raisonné (Toronto: Art Gallery of Ontario, 2003), 210. The plates in the portfolio are albumen prints, and two were printed from two negatives each. lbid., 219.

${ }_{33}^{33}$ Ibid., 219. Illustrations of the portfolio case and Tripe's note are included on page 211.

${ }^{34}$ Other such examples include August Salzmann's (1824-1872) Jerusalem, Étude et reproduction photographique des monuments de la ville sainte depuis l'époque judaique jusqu'à nos jours (1856), of which there is a copy at the Metropolitan Museum of Art (2005.100.373); and Dr. Charles-Édouard Hocquard's (1853-1911) Le Tonkin, Vues Photographiques prises par Mr le Dr Hocquard, Médecin-Major Avec L'Autorisation de Mr Le Général en Chef du Corps Expéditionnaire 1884-1885, Deuxième Série, held at George Eastman House in Rochester, New York (1973:0222:0001-0038). Of course, portfolios were also made in the service of other disciplines, including the sciences. The Metropolitan Museum has one such example, Versuche über Photographie mittelst der Röntgen'schen Strahlen (1869) by Josef Maria Eder (18551944), a set of fifteen photogravures made from human and animal x-rays (2011.66.1-.15).

${ }^{35}$ Tripe's Burma Views was, for example, distributed variously to members of the Government of India and the East India Company's Court of Directors. See Dewan, The Photographs of Linnaeus Tripe, 211. ${ }^{36}$ Hamber, "Facsimile, Scholarship, and Commerce," 133.
} 
simply lost. ${ }^{37}$ Others may remain intact but have been bound later, thus sometimes obscuring their status as portfolios. One such example is Bedford's Tour in the East portfolios discussed earlier. The Prince of Wales himself owned what is apparently a copy of the published Day \& Son portfolios, supplemented with nineteen additional plates, and bound into four leather-bound volumes. ${ }^{38}$

Toward the end of the nineteenth century and into the beginning of the twentieth, the type and purpose of portfolios shifted along with the developing cultural understanding of photography itself. In 1899 and 1900, Alfred Stieglitz (1864-1946) published two portfolios titled American Pictorial Photography (series one and two, respectively), supplements to Camera Notes containing sumptuous photogravuresprinted in various colours and mounted on a range of papers_-of work by a stable of prominent Pictorialists, including Gertrude Käsebier (1852-1934), F. Holland Day (18641933), and Clarence White (1871-1925). Meanwhile, a few years later and on a much grander scale, Edward Sherriff Curtis (1868-1952) published, between 1907 and 1930, his opus The North American Indian, in which each of the set's twenty generously illustrated volumes of text was accompanied by a large portfolio of additional photogravures. Somewhere between an ethnographic project and a Pictorialist art work, The North American Indian was intended to be printed in an edition of 500, of which only around half were actually produced. Notably, both Curtis's and Stieglitz's projects were editioned and numbered (the two series of American Pictorial Photography were each printed in an edition of 150), the earliest such instances I have so far located. ${ }^{39}$

\footnotetext{
${ }^{37}$ Of the fifty original copies of Burma Views, Dewan lists only seven extant examples, of which most are incomplete. (Dewan, The Photographs of Linnaeus Tripe, 219.) Hamber too mentions the 1857-1858 publication Photographs of the "Gems of the Art Treasures Exhibition," Manchester, 1857 (P. \& D. Colnaghi and Thomas Agnew), whose prints were often split up into additional portfolios, and, decades later, discarded in favour of more technologically advanced reproductions. (Hamber, "Facsimile, Scholarship, and Commerce," 133.)

${ }^{38}$ Gordon, Cairo to Constantinople, 223.

${ }^{39}$ The Metropolitan Museum of Art owns a full set of The North American Indian (copy 160/500, the portfolios are accession numbers 1976.505.1-20), as well as both series of American Pictorial Photography (copies 27/150 [1991.1073.101] and 1/150 [22.194], respectively). Not unlike the Bedford instance just discussed, the copy of series one was bound into a book at an unspecified later date, although it remains classified as a portfolio in the museum's database.
} 
In these examples, the historical lineage of the portfolio clearly acts as another visual link between photography and more traditional graphic arts, serving the overarching Pictorialist mandate of promoting photography as a legitimate creative medium. Notwithstanding Pictorialism's subsequent ouster in favor of modernism and straight photography, the promotion of photography as a fine art remained the chief motivation behind many of the portfolios produced in the first half of the twentieth century (and, one might argue, much later than that). ${ }^{40}$ The most prominent examples of this era come, unsurprisingly, from such dedicated and well-known straight photographers as Edward and Brett Weston (1886-1958 and 1911-1983, respectively), Minor White (19081976), Paul Strand, and Ansel Adams, ${ }^{41}$ as well as from Pictorialist holdovers such as Adams's bête noire, William Mortensen (1897-1965). ${ }^{42}$ In Europe, where the cultural trajectory of photography was markedly different, portfolios of work were also published periodically among the avant-garde. In the 1920s and 1930s, both Man Ray (1890-1976) and Germaine Krull (1897-1985) published work in this format, although it is worth noting that many of these examples contain photomechanical reproductions, and had little to do with the emphasis on interpretive fine art printing so prevalent in the United States. ${ }^{43}$

It wasn't until end of the 1960s and the beginning of the 1970s, however, that the expansion of the photography market engendered a concurrent proliferation of the photography portfolio. As early as March of 1971, Beaumont Newhall and Van Deren

\footnotetext{
${ }^{40}$ The nascent Department of Photography at the Museum of Modern Art also saw portfolios as a way to expand cultural literacy about photography. Nancy Newhall's proposed program for 1944-1947 makes repeated mention of portfolios, suggesting editions of "original prints by outstanding photographers" as well as portfolios of "fine reproductions." She suggests that both be made available by subscription to institutions and collectors, based on the understanding that "the vast majority of people do not know what a fine original print looks like, nor do such prints exist in most institutional collections." See Nancy Newhall, "Department of Photography: Proposed program 1844-1947," Beaumont and Nancy Newhall Papers, Box 80, folder 6, Getty Research Institute, Special Collections, Los Angeles. I am grateful to Olivier Lugon for drawing this reference to my attention.

${ }^{41}$ See, to cite just a few examples, Ansel Adams, Parmelian Prints of the High Sierras, (San Francisco: Jean Chambers Moore, 1927); Brett Weston, San Francisco, (Carmel, CA: Brett Weston, 1939); Paul Strand, Photographs of Mexico, (New York: Virginia Stevens, 1940); Minor White, Fourth Sequence, (n.p.: 1950); Edward Weston, Fiftieth Anniversary Portfolio, (Carmel, CA: Edward Weston, 1951).

${ }^{42}$ William Mortensen, Pictorial Photography, (n.p.: ca. 1935), among others.

${ }^{43}$ See Germaine Krull, Métal, (Paris: Librairie des Arts Décoratifs, 1928), and Études de Nu, (Paris: Librairie des Arts Décoratifs, 1930); Man Ray, Electricité, (Paris: Compagnie Parisienne de Distribution de l'Eléctricité, 1931), and La Photographie n'est pas L'Art, (Paris: Guy Levis-Mano [G.L.M.], 1937). Electricité, as its publishing credit indicates, was a commission financed by a Parisian electric company.
} 
Coke predicted, with remarkable foresight, that the 1970s were on track to become "the decade of the portfolios." ${ }^{\prime 44}$ As the chapters by Witkin and Blodgett-discussed earliersuggest, the portfolio during this era was used increasingly as a convenient response to the rising mania for photographic prints, and indeed Witkin's list of portfolios contains an overwhelming majority of examples from this decade. Dealers, galleries, and even the estates of deceased photographers jumped on the bandwagon, producing scores of portfolios of widely varying quality. ${ }^{45}$ At the same time, the rise of the portfolio coincided with an increasing fluidity between photography and the art world more broadly, not just in terms of the market but also in terms of creative production and critical dialogue. Photography also began to enter educational institutions, as departments dedicated to the medium appeared in universities for the first time. Accordingly, there are portfolios from this era that represent all of these developments, including highly polished retrospective examples produced by galleries, such as those published by the Aperture Foundation of Paul Strand's work starting in $1976 ;^{46}$ group portfolios turned out by schools to showcase the work of students and faculty, such as those produced by the Art Institute of Chicago (starting in 1969), the Rhode Island School of Design (starting in 1968), and the Rochester Institute of Technology (starting in 1973); ${ }^{47}$ hybrid art works that stretch the boundaries of both the format and the medium by the likes of Bea Nettles (b. 1946), Mike Mandel (b. 1950), and Robert Heinecken (1931-2006), ${ }^{48}$ as well as photography portfolios made by artists not generally characterized as photographers, such as Eleven Color Photographs by

\footnotetext{
${ }^{44}$ Beaumont Newhall and Van Deren Coke, "Editorial," Image 14, no. 3 (June 1971): 1.

${ }^{45}$ The portfolio of nine reprints from František Drtikol's original glass negatives (Rochester, NY: George Eastman House, 1975) is one instructively egregious example of a posthumous portfolio in which the prints appear to have been made with a striking lack of regard for the photographer's original work. The neutral black and white gelatin silver prints bear scant resemblance to Drtikol's pigment prints - the medium in which he first printed at least a portion of these negatives-or even to his own gelatin silver prints. The portfolio itself also contains no textual indication that it is, in fact, a portfolio of reprints. On the other hand, Six Nudes of Neil, 1925 (New York: Witkin Gallery, 1977), a portfolio of palladium prints made by George Tice from Edward Weston's negatives and containing a text by Cole Weston, possesses a beauty distinct from, but arguably on par with, Weston's original prints.

${ }^{46}$ Portfolio 1: On My Doorstep (1976), Portfolio 2: The Garden (1976), Portfolio 3 (1981), and Portfolio 4 (1981), all Millerton, NY: Aperture Foundation.

${ }^{47}$ Witkin, "Limited-Edition Portfolios," 292-93.

${ }^{48}$ See Bea Nettles, Mountain Dream Tarot, (Rochester, NY: Bea Nettles, 1975); Mike Mandel, BaseballPhotographer Trading Cards (Santa Cruz, CA: Mike Mandel, 1975); Robert Heinecken, Are You Rea? (Los Angeles: 1968), and Just Good Eats For U Diner (Los Angeles: 1971).
} 
Bruce Nauman (b. 1941); ${ }^{49}$ and mass-market ventures such as the four Eight Photographs portfolios produced in 1970 and 1971 by Doubleday \& Company, and priced at "less than $\$ 1$ per print." ${ }^{\prime 50}$

Although the portfolio continues to be used in many of the ways established prior to and during the 1970s, its widespread production has waned significantly since that initial flush of enthusiasm. One possible explanation is that, in a sense, one of the chief objectives of many portfolios-to facilitate the acceptance of photography into the mainstream art world — has by now been decisively accomplished. Furthermore, as institutions and individuals alike have become more knowledgeable about the medium, there is perhaps less anxiety about the "difficult aesthetic judgments" required to choose individual photographs for purchase, something that the pre-emptively authoritative selection implied by a portfolio might have allayed in the earlier years of the market. ${ }^{51}$ In addition, major shifts in the form and scale of much photographic work over the past few decades - think of the monumental prints of Andreas Gursky (b. 1955) or Jeff Wall (b. 1946) as but two of many possible examples—has in some cases rendered the intimacy of the portfolio essentially moot. ${ }^{52}$

Nonetheless, portfolios continue to be made for both commercial and creative reasons, and photographers continue to use the format in ways that reflect and enrich particular bodies of work. For example, in 1982, Michael Snow (b. 1929) produced Still Living: 4 Acts - Scene 1, a portfolio of dye-transfer reproductions of SX-70 Polaroid stilllifes, which the artist described as a "merging of textual, painting, sculptural, theatrical,

\footnotetext{
${ }^{49}$ Bruce Nauman, Eleven Color Photographs (New York: Leo Castelli Gallery, 1970). This work is usually cited with the dates 1966-67/1970, as the original photographs were made as unique prints and meant to be sold separately, although they were often exhibited as a group. It was only after several prints were damaged in 1970 that Leo Castelli suggested that they be reprinted as a portfolio, in an edition of eight, and the remaining earlier prints were (ostensibly) destroyed. For more detailed information, see Neal David Benezra, et al., Bruce Nauman: Exhibition Catalogue and Catalogue Raisonné (Minneapolis: Walker Art Center, 1994), 242-243.

${ }^{50}$ Leslie Krims: Eight Photographs (1970), Jerry Uelsmann: Eight Photographs (1970), Arthur Freed: Eight Photographs (1971), and Edward Weston: Eight Photographs (1971).

${ }^{51}$ Blodgett, "The Pros and Cons of Limited-Edition Portfolios," 121.

${ }^{52}$ The National Gallery of Canada in Ottawa, for example, owns a copy of the portfolio How You Look at It (Hannover: Sprengel Museum Hannover, 2000), which contains photographs, none much larger than approximately $40 \times 30 \mathrm{~cm}$, by eight photographers including Andreas Gursky, Thomas Ruff, Rineke Djikstra, and Bernard Fuchs, many of whom normally produce work on a much larger scale.
} 
and photographic concerns." ${ }^{\prime 53}$ The 1999 Attracted to Light portfolio by Mike and Doug Starn (b. 1961), and the 2004 portfolio La Boîte en Bois by Hiroshi Sugimoto (b. 1948) are two further instances of photographers embracing the portfolio as a key physical component in a multifaceted photographic project. ${ }^{54}$

It is worth making a final remark about the use of photomechanical reproduction in photography portfolios. As I will examine in the following section about photography books, as well as in some of the later examples of individual portfolios, the use and status of photomechanical reproduction has varied considerably throughout the history of the portfolio and throughout the history of photography. In nineteenth-century Europe, portfolios such as the duc de Luynes's Voyage d'Exploration à la Mer Morte à Petra et sur la Rive Gauche du Jourdain, discussed earlier, made use of photogravure presumably for its stability relative to the photographic processes of the time. ${ }^{55}$ In the Pictorialist-era portfolios also discussed, the painterly qualities of photogravure - which could be handmanipulated and printed in a range of colours - were exploited to heighten the visual connection between photography and traditional art mediums. Paul Strand, who used photogravure for the two editions of his Mexican portfolio, saw these high-quality reproductions as a compromise between his belief in the legitimacy of photography as an art form, and his desire to make his work widely available, at least in comparison to the

\footnotetext{
${ }^{53}$ Introductory text from Michael Snow, Still Living: 4 Acts - Scene 1, 1982. Copy in the collection of the Art Gallery of Ontario, Toronto, accession number 82/184.1-10.

${ }^{54}$ The deluxe edition of Attracted to Light (New York?: Nancy Bressler Editions, 1999), a copy of which is at the Metropolitan Museum of Art (2000.440a-n), consists of a maple specimen box containing fourteen photographs of moths, printed on Thai mulberry paper hand-coated with gelatin silver emulsion. The box contains a drawer to hold thirteen of the prints, and a hinged glass top containing an additional print and mylar title sheet, pinned-like an insect-with four T-pins. Meanwhile, Sugimoto's La Boîte en Bois (New York: Caroline Nitsch, 2004), which is based on Marcel Duchamp's The Large Glass (1915-1923), contains two "original, unique negatives by the artist" along with contact prints of each, sandwiched between glass and housed in a "Japanese wooden box." (See the Caroline Nitsch gallery website, last accessed June 16, 2013, http://carolinanitsch.com/projects/hiroshi-sugimoto/.) Certainly both of these portfolios are highly salable luxury items, but both also significantly extend the concept of the portfolio, creating complex objects that enrich a particular photographic project, wholes that are indeed more than the sum of their parts.

${ }^{55}$ The duc du Luynes is well known, of course, for sponsoring the 1856 competition in which a cash prize was offered to the inventor of the best process for creating permanent photographic prints. Nègre-who printed the photogravures in Voyage d'Exploration - though not ultimately the winner (that distinction was conferred to Alphonse Poitevin in 1867), was considered among the top contenders. See Malcolm Daniel, "The Beginnings of Photogravure in Nineteenth-Century France" (Paper presented at the Institute for Research in Art/Graphicstudio, University of South Florida, Tampa, March 1995).
} 
limited exposure provided by his generally sporadic exhibitions. ${ }^{56}$ Meanwhile, the use of more commercial printing processes in the (often conspicuously inexpensive) portfolios of Les Krims, Robert Heinecken, and those produced by Doubleday \& Company, served to undermine (sometimes unintentionally) the supposed purity and preciousness of the photographic medium, and even the rarified quality of the portfolio format itself. This very sense of the artistic primacy of the original fine print, however, has largely been a construction of the twentieth century, of North American photographic discourse in particular, and increasingly of the photography marketplace. In considering these and other examples, it seems clear that various forms of photomechanical reproduction have served both pragmatic and expressive functions in creating photographic bodies of work, including portfolios, and that they have not always been relegated to a kind of runner-up status in comparison to original prints. Thus, despite the fact that portfolios are often assumed to be synonymous with the fine photographic print, photomechanical reproduction has long been an important component in their development and purpose.

${ }^{56} \mathrm{I}$ discuss this in greater detail in section 4.1, on Paul Strand's Photographs of Mexico. 


\section{Photography Books and Portfolios}

It is no longer a revelation that to adequately analyze and interpret photographs, it is crucial to examine them within the original context of their making and their dissemination; or that in many, if not most cases, this context includes not just isolated, monolithic works but entire groups of images. In considering the portfolio as a format for compiling such groups-along with its kin, the photography book, with its bound pages and often much larger edition size-one must consider not only the selection and ordering of the images themselves, but the physical and material ways in which they are produced, presented, and consumed. These two formats, as alluded to previously, can be considered branches of the same tree, in that they collect a set of photographs within one or more specially designed delimiting structures - the page and the book cover, the portfolio boxand often seek to elaborate on the meaning of those photographs through the use of text. In this section, I will therefore address some of the physical particularities that both relate and distinguish photography books and portfolios.

In her 1989 article "On Reading Photographic Books," Kim Sichel points out that although not all photography books are made in the same ways or for the same reasons, all are linked by the fact that they can be read "both as narratives and as visual objects." For the sake of clarity, however, I will be more narrowly concerned here with interpretations of such photography books as those defined by Chris Balaschak as "produced as publications for the sake of being books, for the sake of embracing photography as an inherently reproducible medium, and using that means to construct a particular view of our world. ${ }^{\prime \prime 58}$ Such photography books, especially as they were developed in the twentieth century as often mass-produced but, at their best, carefully conceived and designed photographic objects, have in fact been cited at times as the

\footnotetext{
${ }^{57}$ Kim Sichel, "On Reading Photographic Books," 3.

${ }^{58}$ Chris Balaschak, "Unstable Ground: Photography Books and the Modern Landscape, 1938-1975," PhD diss., (University of California, Irvine, 2010), 9. The books that Balaschak considers specifically are Walker Evans's American Photographs (1938), Robert Frank's The Americans (1959), Ed Ruscha's Twentysix Gasoline Stations (1962), Bernd and Hilla Becher's Anonyme Skulpturen (1970), Lewis Baltz's The New Industrial Parks Near Irvine, California (1974), and Judy Fiskin's Thirty-One Views of San Bernardino (1975).
} 
optimal format for viewing photographs, ${ }^{59}$ based on two primary threads of reasoning. One of these is the way that numerous design choices (such as typography, layout, printing, and binding), along with the physical circumscription of the book format, work in tandem to advance the expressive aims of a photographic sequence. ${ }^{60}$ This is also tied to the collaborative nature of book-making, which in most cases requires the expertise and technical skills of persons other than the photographer alone. The other argument hinges on the intimacy, portability, and supposed democracy (because of its relative accessibility in terms of cost and the potential for widespread distribution) of the photography book, which allows the book to be accessed on a one-to-one scale by a large, dispersed audience, and studied over a theoretically unlimited period of time and under all manner of circumstances. Both of these points can be additionally applied, with certain caveats, to the portfolio format, but can also serve to highlight some of the qualities that distinguish portfolios from their bound counterparts, and to complicate the ways that they function as objects.

In his 1999 article "Photographs as Material Culture: A Primer for Collectors," A. D. Coleman elaborates on the distinction between the photograph as image and the photograph as object, and suggests that "each photographer establishes his or her personal version of the relationship between camera vision and the printmaker's craft." He goes on to posit that this relationship explicitly determines the "inherent significance" of the final

\footnotetext{
${ }^{59}$ A. D. Coleman proposes, for example, that the "book form is a more suitable vehicle for much contemporary photography than the original-print form we've come to value so highly." (See Coleman, "Some Notes on the Photography Book," 116.) Martin Parr and Gerry Badger, as well as Andrew Roth, explicitly use the word "natural" in describing the affinity between books and photography: "The photographic medium is especially well suited to the book, the most natural format for sequencing reproductions" (Andrew Roth, ed., The Book of 101 Books [New York: PPP Editions in association with Roth Horowitz LLC, 2001], 1); and, "we believe that there is a discernible third, intermediate forum [in addition to magazines and galleries] for the photographic auteur-the medium of the photobook-and that this can be considered photography's 'natural' home." (Parr and Badger, The Photobook, vol. 1, 11).

${ }^{60}$ It is relevant to distinguish here between the words series and sequence. The first, series, indicates a (potentially infinite) succession of like things, and is based on an etymological root meaning "to link or join." Sequence, meanwhile, is based on the root "to follow," and has to do with causality and the relationship between items. In terms of books and portfolios, then, we speak of sequencing as the intentional ordering of a finite set of photographs to create meaning and sometimes narrative, based on the relationships between those images. A series, on the other hand, would more simply imply a continuous, and potentially ongoing, string of related images, all pertaining to the same subject or theme.
} 
physical format in which a photographer's work is produced. ${ }^{61}$ This idea is useful for developing an understanding of how a photographer's vision, as well as his or her involvement in the physical creation of a book or portfolio, has a number of implications in terms of both personal expression and commodity value in the market.

As with the portfolios on which I am focusing, the photography books that have generally garnered the most serious attention (in the surveys I have already discussed, for example) are those created under the auspices of individual photographers, to represent a particular concept or body of work. As a number of writers have pointed out, however, it is rare that books and portfolios are ever truly the work of a single person, but instead rely in most cases on a collaboration between multiple parties. ${ }^{62}$ The most lauded photography books are those whose selection of powerful images-effectively reproduced and compellingly sequenced—and sympathetic design converge to create a singular object greater, as so many put it, than the sum of its parts. But it is just these qualities that tend to indicate the prowess of contributors other than the photographer alone, even when all are acting in the service of the photographer's particular vision. To take just one example, Lee Friedlander's second book, Self Portrait, was published by his own home-grown Haywire Press — whose very name attests to its seat-of-the-pants ethos—and funded with the proceeds from his first portfolio, Photographs \& Etchings. But while Self Portrait marks the first of Friedlander's many self-directed publications, both under his own and other publishing imprints, it can also be said to represent the start of a parallel "miniature history" of the work of Richard Benson, one of a number of commercial printers who, in the 1960s and onward, continually tackled and advanced the problem of effectively

\footnotetext{
${ }^{61}$ A. D. Coleman, "Photography as Material Culture: A Primer for Collectors," Art on Paper 4, no. 1 (September-October 1999): 51. Perhaps tellingly, the question of inherent significance versus collectability and connoisseurship dates as least as far back, like editioning, as Britain's nineteenth-century "etching revival." Emma Chambers quotes Joseph Maberly from his 1844 volume The Print Collector: An Introduction to the Knowledge Necessary for Forming a Collection of Ancient Prints (London: Saunders and Otley), in which he asks, "May not the amateur be content with possessing that one state [of an etching], whichever it may be, which is as a work of art the most intrinsically valuable?" See Chambers, An Indolent and Blundering Art?, 74.

${ }^{62}$ Kim Sichel makes note of this ("On Reading Photographic Books," 3), as do Parr and Badger (The Photobook, vol. 1, 10).
} 
reproducing photographs by way of offset lithography.${ }^{63}$ Friedlander himself, when referring to the production of Self Portrait, has noted that "everybody I knew helped me." ${ }^{164}$ A finished book, then, might be representative of a photographer's own ideas and decisions, but it is usually shaped significantly-in a best-case scenario, one might say nourished-by the collaborative efforts of printers, binders, and in many cases additional contributors such as designers and publishers. Furthermore, in the transition from original photograph to printed image, the look and feel of the finished page is entirely dependent on available materials, technologies, and indeed technicians. At the same time, these additional factors and collaborators tend not to be explicitly acknowledged or considered in the evaluation of the finished book as to either its expressive merit or its market value.

These issues also come into play in the production of portfolios, but with some important variations. Because portfolios are usually comprised of original photographs, the photographer's involvement is somewhat more fraught. For many portfolios, particularly those made in the twentieth century, and even more specifically those made in North America, the crux of both their artistic and commercial value is the fact that they contain actual photographs, and as such represent another way of selling and buying individual prints, compiled for reasons of convenience, marketability, or creative intent. Therefore, the question of whose hands made these prints (and not only the negatives from whence they came) is often a key component in a portfolio's purpose as well as its salability. The portfolios made by Ansel Adams starting in the 1920s, for example, were specifically intended to advance the notion of photography as a fine art-inextricably linked, in his case, to personal, interpretive photographic printing. The photographs contained, meanwhile, in Berenice Abbott's 1956 portfolio of modern gelatin silver reprints from Eugène Atget's negatives, are entirely unlike the prints created by Atget himself-who did not, however, consider himself an artist or a fine printmaker ${ }^{65}$ - but served the purpose of

\footnotetext{
${ }^{63}$ Richard Benson, "Working with Lee," in Galassi, Friedlander, 436. Peter Galassi also details Friedlander's working relationship with a large array of additional designers, printers, and publishers. See Galassi, Friedlander, 444-445.

${ }^{64}$ Ibid., 41.

${ }^{65}$ As illustrated, for example, by his well-known comment to Man Ray about his own photographs, "These are simply documents I make." See Paul Hill and Thomas Cooper, "Man Ray," interview in Dialogue with Photography (New York: Farrar, Straus, and Giroux, 1979), 24.
} 
raising funds and promoting the deceased photographer's legacy. (Both of these examples will be developed further in subsequent chapters.) With the rise of the photography market in the 1970s, there came a flood of often cursory retrospective portfolios, frequently subsidized by galleries and printed by technicians other than the photographers themselves. In the case of work by artists who were still alive, this was often done under supervision, but there also exist many examples of posthumous portfolios printed with widely varying degrees of sensitivity for the photographer's original working methods. ${ }^{66}$ On the other hand, the same burgeoning market has been responsible for the valorization of the vintage print as the ultimate collectible photographic object, with an accordingly elevated price tag.

It is important, however, to note both that the original photographic print is not every photographer's intended end product, and also that it is indispensible for some. ${ }^{67}$ With this in mind, then, the relative expressive value of the portfolio versus the photography book must be assessed on a case by case basis. For interpretive printers such as Ansel Adams or Brett Weston, both of whom made many portfolios throughout their careers, original photographs were essential for properly understanding and appreciating their work. ${ }^{68}$ (It is worth remarking that for Adams's first book, Taos Pueblo, published in 1930, the photographer himself made the twelve original prints to be tipped in to the entire edition of 108 copies, in the absence of an accessible source of sufficiently highquality photomechanical printing. ${ }^{69}$ ) Compare these photographers, as Coleman does, to

\footnotetext{
${ }^{66}$ The 1975 Drtikol portfolio published by George Eastman House, and the Witkin Gallery's Six Nudes of Neil, 1925, both cited on page 16, illustrate something of this range. Another example of a fine posthumous portfolio might be Charles Sheeler: Photographer at The Metropolitan Museum of Art, produced in 1982 by the museum, which retains a mock-up of the project in its collection (the full edition of 250 was apparently never completed), accession number 1982.1189. The exquisite prints in this portfolio were made by Alan B. Newman on hand-coated platinum paper, chosen to best replicate Sheeler's original gelatin silver prints, a decision outlined in the portfolio's introductory text by Weston Naef.

${ }^{67}$ Coleman, "A Primer for Collectors."

${ }^{68}$ Edward Weston, meanwhile, made only one portfolio, the $50^{\text {th }}$ Anniversary Portfolio, and that towards the end of his life, in 1952. As he was already suffering from Parkinson's disease at the time, the actual printing of the portfolio was carried out under his supervision by his son Brett, and others. Weston also published very few books during his lifetime, leaning instead toward stand-alone prints and exhibitions.

${ }^{69}$ Shelley Rice, "When Objects Dream," in Roth, The Book of 101 Books, 6-7.
} 
Weegee, or, as George Tice did, to Brassaï and Henri Cartier-Bresson. ${ }^{70}$ For these three latter examples, along with many others, it is the ink-based photomechanical printwhether in a newspaper, magazine, or photography book-that stands out as the fully realized embodiment of their work, rather than the gelatin silver photograph, however rare or personally crafted it might be.

Another major difference between original prints and photomechanical reproductions is the aspect of dissemination and accessibility. This brings us back to the second line of reasoning alluded to earlier, that the photography book can be considered the ultimate format for viewing photographs because of its intimacy and democracy. Andrew Roth, in his introduction to The Book of 101 Books, suggests that photography is "one of the most intimate mediums," in part because "our encounter with it is generally under a soft light and on our lap." ${ }^{171}$ Coleman too mentions his predilection for reading photography books "early in the morning, late at night, in the bathtub, sitting on my front steps. ${ }^{172}$ In contrast to these cozy images, both proponents and detractors tend to make much of the rarified luxuriousness of the photography portfolio, and it is almost always linked to the notion of editioning - that is, purposefully limiting the number of available copies and precluding the possibility of more copies in the future. In terms of accessibility, then, the limited edition portfolio and the mass-produced photography book would seem to stand on opposite poles, but the reality may be somewhat more nuanced.

It is certainly true that, generally speaking, a newly published photography book will nearly always cost less than a newly published portfolio, and will nearly always be produced in larger numbers and be more widely distributed. As librarian and curator May Castleberry points out, however, once photography books go out of print, they can in fact become "one of the least accessible of art objects," owing to the same small scale,

\footnotetext{
${ }^{70}$ Coleman argues convincingly that, for Weegee, "a photographic print was usually nothing more than a disposable by-product" intended to be translated into halftone or photogravure illustrations in books, magazines, and newspapers. (Coleman, "A Primer for Collectors," 51.) In his interview with Tom Dugan, Tice meanwhile describes Brassaï's original prints as "crassy," and suggests that both his and CartierBresson's work benefits significantly by being reproduced in ink. (Dugan, "George Tice," in Photography Between Covers, 165.)

${ }^{71}$ Roth, The Book of 101 Books, 1.

${ }^{72}$ Coleman, "Some Notes on the Photography Book," 117.
} 
inexpensive production, and intimacy that initially makes them so democratic. ${ }^{73} \mathrm{~A}$ photography book (often printed on acidic commercial paper) can easily become fragile with age, and because books by their very nature must be held and manipulated in order to be fully appreciated, this fragility is a true liability in terms of access. A photograph, meanwhile, even if similarly delicate, might nonetheless be protected by a mat when stored or handled, or sealed behind glass when hung on the wall, and may thus retain something of a public life. The declaration common to so many portfolio texts-that the photographs have been printed and mounted with strict adherence to archival standardscan sometimes sound precious, but over the course of time becomes the saving grace of many such objects. Of course, the much-lauded democracy of photography books is also imperiled by their relatively recent entry into the mainstream photography market, where they command ever increasing prices, particularly for scarce or classic publications celebrated in surveys such as Roth's, and Parr and Badger's. Books have the significant benefit of being reprintable, but aside from the fact that they aren't usually restricted by the same anxieties about editioning that portfolios often are, the re-publication of a book can be an elaborate and expensive undertaking, and only likely to be carried out under particularly felicitous circumstances. ${ }^{74}$ Furthermore, once we consider the issue of republishing, we must also return to that distinct confluence of printing technologies, paper, design, binding, and so on, that makes up the transcendent, expressive whole of the photography book. One need only compare successive editions of some of the most iconic photography books of the twentieth century-Walker Evans's Many Are Called is one such example-to see how many differences arise as tastes and technologies evolve over time. ${ }^{75}$

\footnotetext{
${ }^{73}$ May Castleberry, "The Presence of the Past," in Roth, The Book of 101 Books, 105.

${ }^{74}$ Ibid., 106.

${ }^{75}$ In this case, it is easy to pinpoint the disparities between the first edition of Evans's book of candid subway portraits (Boston: Houghton Mifflin, 1966) and a more recent reprint (New Haven: Yale University Press; New York: Metropolitan Museum of Art, 2004). Although the design by Katy Holman remains substantially true to the original, the later edition is notably larger (including the scale of the photographs themselves), the cover and typography are different, additional essays have been added, and the reproductions themselves are warmer-toned, less contrasty, and are varnished to a high gloss. Although attractive, the overall effect of the reprint is something of a departure from that of the first edition, with its simple black cover, small scale, and the matte, dark grittiness of its reproductions.
} 
Finally, it is impossible to compare photography books and portfolios without discussing the chief difference in their physical structure, namely the fact that the pages of books are bound, while the prints contained in a portfolio are not. This simple variation is critical to the way that these bodies of work are read, as well as to their lives within the private home, the library, or the museum. As Kim Sichel notes, "we are meant to hold [books] in our laps, to turn pages, and to follow a certain predetermined progression.."76 These stipulations can apply to portfolios as well, but more often do not, or not without some modification. First, in addition to being comprised of loose-although often mounted and even matted — photographs, portfolios are often oversized, larger (sometimes much larger) than an average book. Not generally suitable for armchair viewing, portfolios tend to require significant room to spread out. At the same time, the act of looking through a portfolio can be even more meditative and intimate than that of reading a book; it slows one down, becomes a kind of ceremony.

Meanwhile, the "predetermined progression" of images, which is the province of the photography book, is complicated by the portfolio's unbound structure. Although some portfolios are meant to be "read" in a given order, ${ }^{77}$ and many portfolios include numbered print lists, the reality is that, due to carelessness or simply through use, portfolios in collections are rarely maintained in their original order, and must be reordered, or not, with each viewing. On the other hand, many portfolios are assembled without any particular indication of order, and in this case such a decision may be underscored by their flexible structure, whereas all photography books are sequenced by their very nature, albeit with more or less attention to the nuances of such an arrangement. In addition, it has often been a selling point of portfolios that they can be broken up for exhibition or re-sale, ${ }^{78}$ and it is not at all uncommon to find unmoored portfolio prints in

\footnotetext{
${ }^{76}$ Sichel, "On Reading Photographic Books," 3.

77 In his introduction to Portfolio Three (San Francisco: Sierra Club, 1960), Ansel Adams notes that "the pictures are put together as a continual pattern of personal mood and response," and continues, "a certain sequence is indicated for esthetic reasons." Perhaps an even more concrete example is the fifty-print portfolio of Larry Clark's Tulsa (New York: RFG Publishing, Inc., 1980), which, although printed later, replicates the narrative sequence of Clark's book of the same name (New York: Lustrum Press, 1971). An earlier portfolio of this work (New York: Lustrum Press, 1975) contains only ten prints from the book and thus would be read quite differently.

${ }^{78}$ See Witkin, "Limited-Edition Portfolios," 277; Blodgett, "The Pros and Cons," 121-22.
} 
museum collections, or exhibitions that display only a small selection of photographs from a larger portfolio. ${ }^{79}$ Thus, in instances where the same body of work exists both as a portfolio and a book, the experience of reading each can vary considerably (the example of Lee Friedlander and Jim Dine's Photographs \& Etchings is discussed in section 4.4). This is not always to the portfolio's detriment, and in some cases, the potential for re-ordering and thus re-reading is part of the format's expressive potential. Minor White, who used sequences extensively, and who continually revisited and revised his past work, published at least two limited edition portfolios, ${ }^{80}$ and constructed others in a less formal capacity. ${ }^{81}$ Photographers such as Duane Michals (b. 1932) and Les Krims have played with the fluidity of the format as well, creating limited edition portfolios in which each copy contains a different configuration of photographs, or is accompanied by different handwritten notes. ${ }^{82}$

Like the book, the portfolio thus represents a distinctive format for compiling and distributing photographs, and, as I have discussed, has its own relationship to such material considerations as printing and sequencing, as well as to the photography market and to the public understanding of photography in general. The selected portfolios that I

\footnotetext{
${ }^{79}$ Due to space constraints, this is frequently true even for exhibitions that have portfolios as their subject. Such was the case for The Portfolio as Object (1981), Boxed Sets (2005), and Out of the Box (2009-10).

${ }^{80}$ Fourth Sequence (n.p.: 1950), one copy in the collection of the Center for Creative Photography, accession number 76.38; Jupiter Portfolio (New York: Light Gallery, 1975), see Witkin, "Limited-Edition Portfolios," 298, and Fine Photographs and Photobooks (New York: Swann Auction Galleries, April 18, 2013), lot 220.

${ }^{81}$ For example Sequence 15, on which White began work in 1959, and which he continued to revise until the early 1960 s. Different sets contain different numbers of prints, and no definitive version seems to exist. A copy auctioned by Sotheby's in 2011 was housed in a black portfolio case and accompanied by two text panels. See "Minor White: Photographs from 'Sequence 15'," Photographs (New York: Sotheby's, October 5 , 2011), lot 121.

${ }^{82}$ Each copy of Les Krims's Idiosyncratic Pictures (Buffalo, NY: Les Krims, 1980) contains fifteen gelatin silver prints, of which a random selection of ten are matted - "to provide an idiosyncratic selection for each person purchasing the portfolio" — as well as two colour contact prints, three unique Polaroid SX-70 prints, and additional ephemera such as "white Kodak handling gloves." (One copy, apparently incomplete, of this portfolio resides at George Eastman House, accession number 2001:1857:01-10. Details on the full portfolio are courtesy of Les Krims, and from the portfolio's colophon.) Meanwhile, Lee Witkin quotes Duane Michals as to his Untitled portfolio (New York: Duane Michals, 1972-) as follows: "Each [portfolio] will be put together with a different selection of photographs and the text will vary as my observations change. ... Portfolios always seem to me like loaves of bread. I've always been troubled by all those similar, impersonal, perfect prints." According to Witkin, each portfolio consists of a sequence of six to eight prints, with Michals's hand-written text. The open publication date indicates that, as of Witkin's writing in 1978, the projected edition of 25 remained incomplete. (Witkin, "Limited-Edition Portfolios," 288-89.) I have not yet located a copy of this portfolio.
} 
will present in the following chapters each represent, in their own ways, varying facets of these concerns, and illustrate a number of ways that individual photographers have used the portfolio format, particularly in the decades leading up to the photography boom of the 1970s. 


\section{Case Studies of Selected Twentieth-Century Portfolios}

In the absence of much substantial writing about the photography portfolio as a specific format, and its place in the broader history of photography, it seems clear that any new elaboration on this topic must hinge on an object-level examination of individual portfolios and of the contexts in which they were created. The eight portfolios I will be discussing in depth may seem initially to be something of a motley selection, and indeed I clearly cannot hope to represent the entire breadth of the format through such a small sample group. Rather, I aim to explore some ways that the photography portfolio has been used by individual practitioners, and how bodies of work presented as portfolios are informed by the particular characteristics and history of the format, and thus to show that the portfolio can and has been used in singularly expressive ways. At the same time, even the inescapably commercial aspects of the format persist as eloquent reminders of some of the central developments and concerns that marked the rise of photography-and art photography in particular-in the twentieth century.

The selected portfolios presented here span the 1940s through the early 1970s. By the 1940s, the standard tropes of the photography portfolio were essentially in place, but the format was not yet widely used by photographers, owing in part to the lack of a real market in which such objects could be expected to sell. By the early 1970s, portfolios had begun to flourish as a vehicle for selling photographs and were soon taken up as an important commercial product for photographers, galleries, and educational institutions. It is not my intention to sketch out a teleological progression over the course of these four decades, but this period seems to me one of the most instructive in the history of the format. My selection, I believe, also suggests the need for further work to be done in extending this history both forward and backward in time, to develop a fuller examination of the origins and the continued use of the photography portfolio.

The first portfolio I will discuss, Photographs of Mexico (1940), along with its second edition, The Mexican Portfolio (1967), by Paul Strand, exemplifies one way that photomechanical reproduction was used in conjunction with the portfolio format in the twentieth century. For Strand, the creation of high-quality hand-pulled photogravures 
represented a compromise between his belief in the primacy of the original photographic print, his political ideals, and a desire for his work to be broadly accessible. The renaming (to The Mexican Portfolio) and significant enlargement of the edition size when the portfolio was reprinted in 1967 (itself a highly unusual decision for a portfolio) are also suggestive of significant changes in the photographic zeitgeist between its first and second printing.

Next, Portfolio One (1948) by Ansel Adams, and 20 Photographs by Eugène Atget, 1856-1927 (1956) selected and printed by Berenice Abbott, represent relatively early examples of some of what may be considered standard characteristics of the format as it continued to be used in subsequent decades. Adams, whose personal practice made appreciation of the original photographic print indispensible, produced eight portfolios between 1927 and the 1976, of which Portfolio One was his second overall, but the first in his series of seven numbered portfolios, which represent the "rather persistent style" of his mature work. ${ }^{83}$ Abbott's portfolio of prints made from Atget's original glass-plate negatives, meanwhile, is an early (though not the first ${ }^{84}$ ) example of a posthumous portfolio, of which many were produced from the 1970s onward. Abbott's case, however, is notable for her unusually close relationship with Atget's work and archive, and her nearly career-long dedication to preserving and promoting his legacy.

Photographs \& Etchings (1969) by Lee Friedlander and Jim Dine is an example of a portfolio by a photographer whose work is better known in the form of conceptually driven book projects, as well as perhaps through exhibition. Lee Friedlander's practice has long been propelled by his photography books, but he has also produced six portfolios, as well as a number of more hybrid forms. Photographs \& Etchings was his first portfolio, published simultaneously as a book, also his first, titled Work From the Same House. This portfolio also represents a relatively unusual, but historically evocative, collaboration between a photographer and a contemporary artist, perhaps a variant of the more common collaborations — in both portfolio and book form—-between photographers and

\footnotetext{
${ }^{83}$ Ansel Adams, The Portfolios of Ansel Adams, v. This phrase is Adams's own, in his preface to the volume.

${ }^{84}$ Earlier examples include the two Lewis Hine Memorial Collection Committee portfolios (New York: Photo League, 1942 and 1946), and the Stieglitz Memorial Portfolio, 1864-1946 (New York: Twice a Year Press, 1947).
} 
writers.

Made just five years after the second edition of Paul Strand's Mexican portfolio, the three portfolios by Les Krims-The Deerslayers, The Little People of America 1971, and The Incredible Case of the Stack O’Wheats Murders (all 1972)_represent an entirely different use of photomechanical reproduction. Together, these portfolios comprise a body of work intended to send up and critique a number of prevailing trends in the world of contemporary photography, with regards to which Krims was both a representative example as well as something of an anomaly. As such, their physical characteristics - their small format, commercial printing technique, and unusually large edition size-also serve to underscore their satirical contents, and can again be both linked and set in opposition to a number of artistic and photographic practices of the day.

These eight examples thus embody a range of approaches, intentions, and historical imperatives that informed the production of portfolios by individual photographers in the decades leading up to the format's full-scale proliferation and the peak of its popularity in the 1970s. In the following sections, I provide a detailed catalogue for each of the portfolios discussed, as well as reproductions of the images contained therein, and of some or all of the attendant materials such as enclosure and text. Following the reproductions are extended commentaries on each selection, in which I examine the ways that these portfolios reveal much about the individual oeuvres of their authors, the historical contexts of their publication, and about the peculiar qualities of the portfolio as an object in itself. 


\subsection{Paul Strand: Photographs of Mexico (1940) and The Mexican Portfolio (1967) Catalogue}

PUBLISHED: New York: Virginia Stevens, 1940 (first edition)

New York: Da Capo Press, 1967 (second edition)

EDITION: 250 (first edition)

1000 (second edition)

COPIES CONSULTED: Unnumbered, Metropolitan Museum of Art, accession number 40.107 (first edition).

Copy 137, Ryerson Image Centre, accession number PA.1973.0496:001 (second edition).

CASE: Both editions are housed in tan cloth-covered folding slipcase. Dimensions: $41.2 \mathrm{x}$ $32.5 \mathrm{~cm}(16.2 \times 12.8 \mathrm{in})$.

TEXT: First edition includes a folio containing an essay by Leo Hurwitz, an introduction by Paul Strand, and a numbered list of print titles.

Second edition includes the same Hurwitz essay and list of prints, but with a different text by Strand, and an additional statement by David Alfaro Siqueiros.

PRINTERS: Otto Wackernagel, Photogravure and Color Company, New York, New York (first edition).

Albert Delong, Anderson Lamb Company, Brooklyn, New York (second edition).

PRINTS: Both editions comprise twenty hand-pulled photogravures on heavy Rives BFK all-rag stock, $40.2 \times 31.8 \mathrm{~cm}(15.75 \times 12.5$ in). Prints vary between $16.2 \times 12.7 \mathrm{~cm}(6.4 \times$ $5.0 \mathrm{in})$ and $25.7 \times 20.3 \mathrm{~cm}(10.1 \times 8.0 \mathrm{in})$. All prints are lacquered with a spray varnish.

1. Near Saltillo

2. Church - Coapiaxtla

3. Virgin - San Felipe - Oaxaca

4. Women of Santa Anna - Michoacan

5. Men of Santa Anna - Michoacan

6. Women - Patzcuaro

7. Boy - Uruapan

8. Cristo - Oaxaca

9. Woman and Boy - Tenancingo

10. Plaza - State of Puebla

11. Man with a Hoe - Los Remedios

12. Calvario - Patzcuaro

13. Cristo - Tlacochoaya - Oaxaca

14. Boy - Hidalgo 
15. Woman and Baby - Hidalgo

16. Girl and Child - Toluca

17. Cristo with Thorns - Huexotla

18. Man - Tenancingo

19. Young Woman and Boy - Toluca

20. Gateway - Hidalgo

REPRODUCTIONS: Although the portfolio copies consulted for this thesis reside at the Metropolitan Museum of Art and the Ryerson Image Centre, the images that follow are of Photographs of Mexico (1940), and were provided by the Paul Strand Archive, Aperture Foundation. These reproductions also appear in James Krippner, Paul Strand in Mexico (México, D.F.: Fundación Televisa; New York: Aperture Foundation: Distributed by D.A.P., 2010), 46-47.

All images are (C) Aperture Foundation, Inc., Paul Strand Archive. 

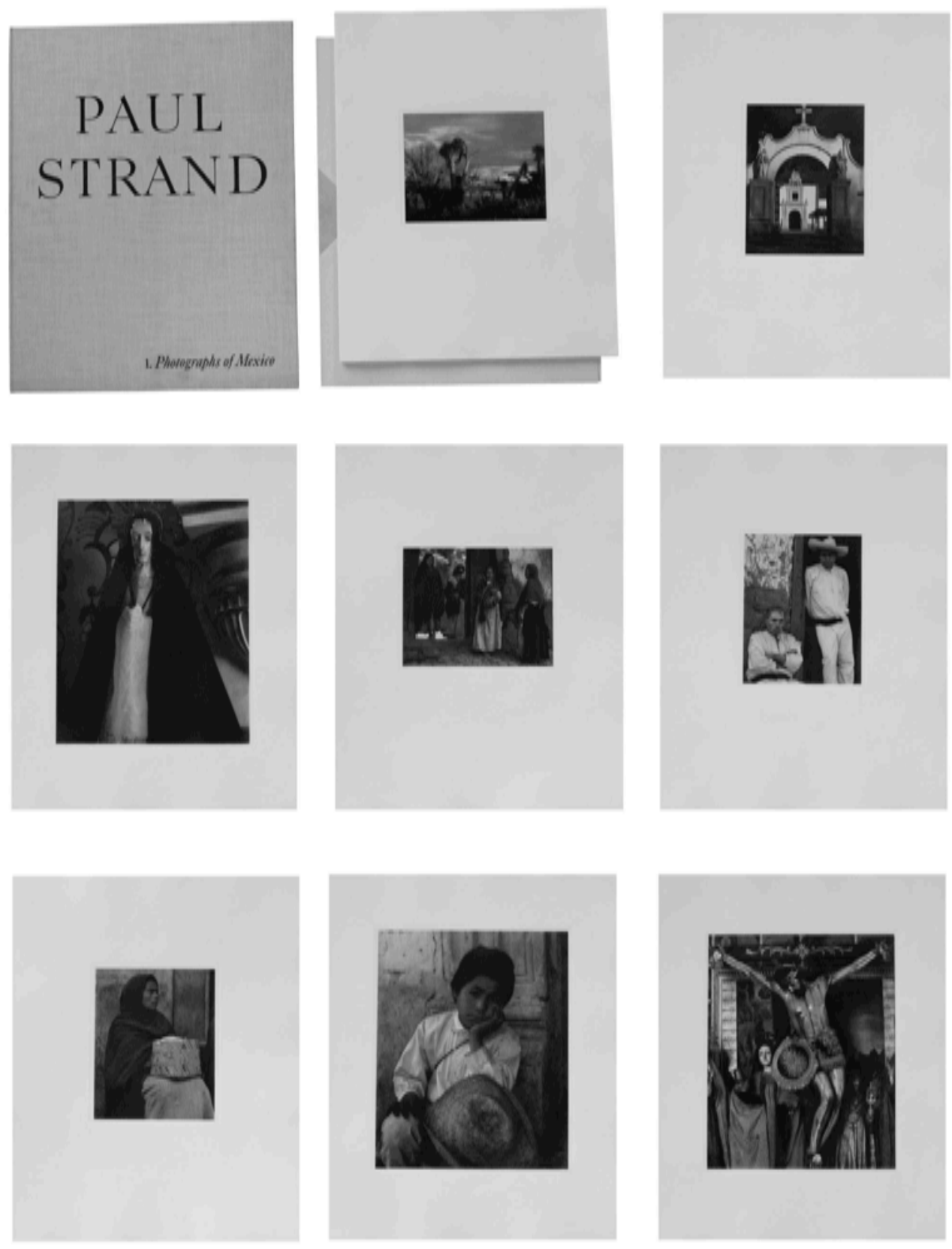

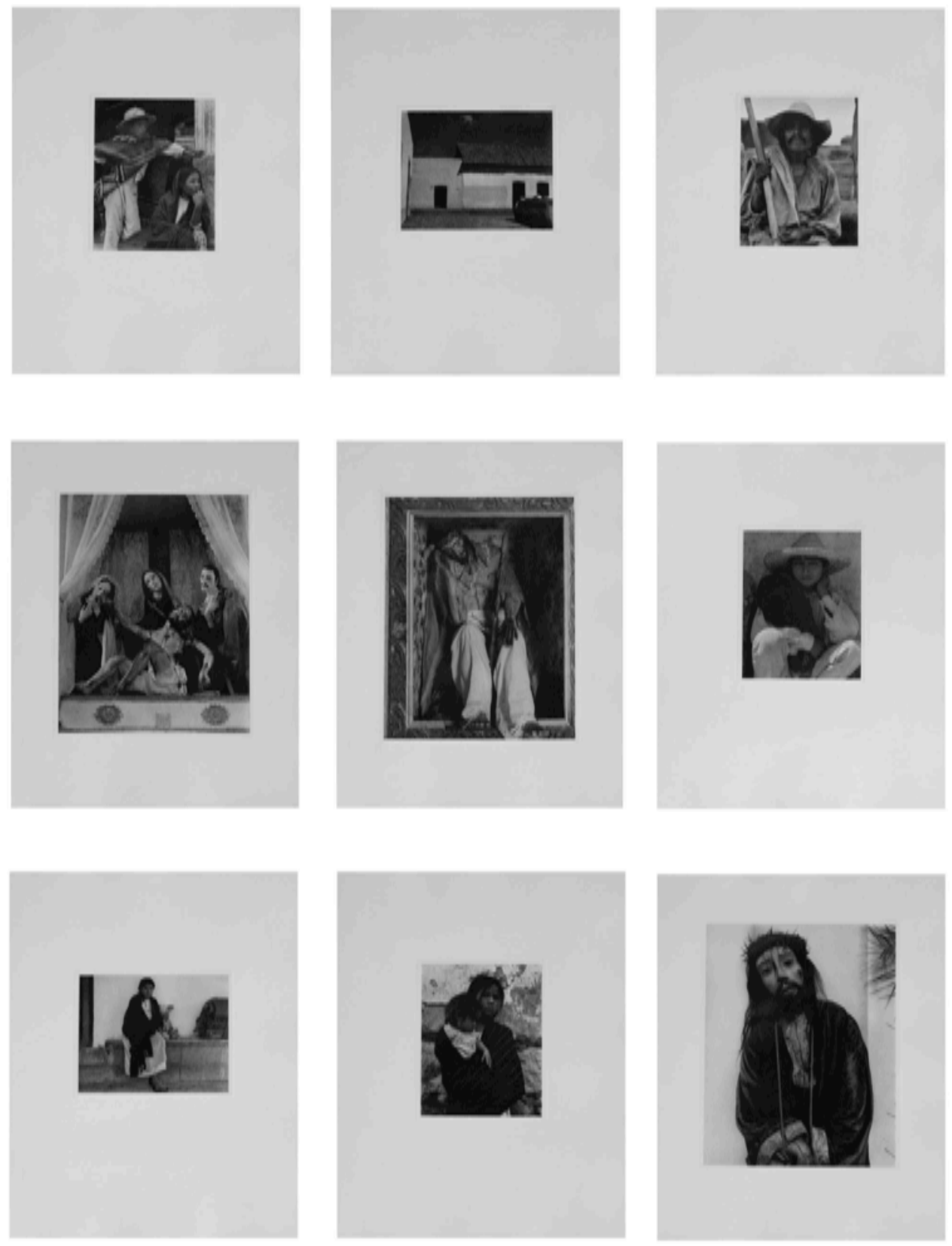

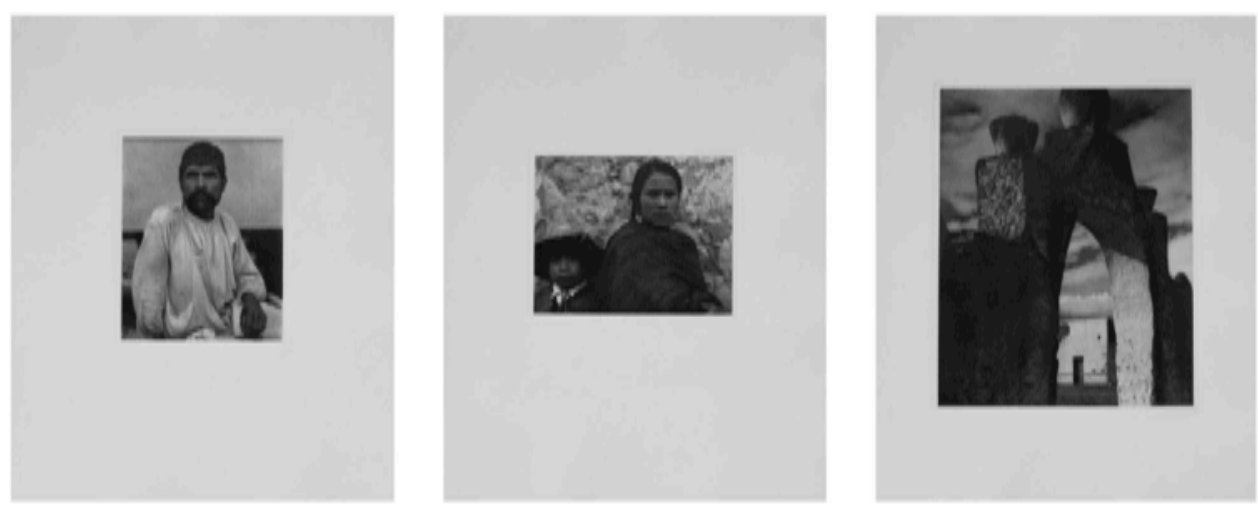


\section{Commentary}

Photographs of Mexico is a portfolio of twenty photogravure prints, made from negatives that Paul Strand took in Mexico in 1932 and 1933. Published in 1940 by Strand's second wife, Virginia Stevens, in an edition of 250, each portfolio originally sold for $\$ 15$. Twenty-seven years later, in 1967, the Da Capo Press, in cooperation with the Aperture Foundation, re-published it as The Mexican Portfolio in an edition of 1000, at a price of $\$ 150$ per copy —a rather unusual example of a portfolio reprint. ${ }^{85}$ Aside from the changes in title, edition size, and price, and the inclusion of a new introduction by Strand and an additional text by the Mexican muralist David Alfaro Siqueiros-the main text by the filmmaker Leo Hurwitz appears in both versions-the two editions of the portfolio are remarkably similar. Photographs of Mexico is a particularly strong example of a portfolio produced and arranged as a specific, considered photographic project, and one whose very existence as a portfolio points directly to the photographer's intentions and concerns. It is perhaps not surprising that, among the eight portfolios chosen for this survey, Photographs of Mexico has been written about in the greatest depth. ${ }^{86}$ This fact is indicative not only of its coherence as an object, and its importance within Strand's oeuvre, but of the circumstances under which it was published and re-published.

During his sojourn in Mexico in 1932-34, Paul Strand produced some 175 negatives, sixty of which he printed in platinum ${ }^{87}$ Of that sixty, he selected twenty to comprise Photographs of Mexico, published seven years after his return to the United States. The portfolio thus represents the major public expression of his time in Mexico, along with Redes (released in the US as The Wave), a film—financed by the Secretaría de Educación Pública-whose entire production Strand oversaw, and on which he worked as cinematographer and scriptwriter. Both the film and the portfolio represent a pivotal stage

\footnotetext{
${ }^{85}$ This price was confirmed in an email to the author from Susan Charlas, registrar at the Paul Strand Archive, on June 11, 2013.

${ }^{86}$ By extension, of course, most of what has been written about the content of Photographs of Mexico applies to The Mexican Portfolio as well.

${ }_{87}$ James Krippner, "Traces, Images and Fictions: Paul Strand in Mexico, 1932-34," The Americas 63, vol. 3 (January 2007): 360.
} 
in Strand's career-long negotiation between his modernist understanding of photography as a fine art, and his commitment to using that art in the service of creating a "visual social history. ${ }^{\prime 88}$ Strand's interest in photography that carried a (sometimes oblique) social message dated as far back as his work in the $1910 \mathrm{~s},{ }^{89}$ but had largely been superseded by a more narrowly formalist approach in subsequent years. His politics had meanwhile taken on an increasingly socialist bent from the 1920s, and his time in Mexico coincided with a full embrace of Marxism (although he never became an official member of the Communist Party), and the projects he undertook there, particularly Redes, bear the stamp of this development..$^{90}$ The Mexico trip also ushered in the ten-year period in which Strand set aside still photography in favour of motion picture work, which in turn led to a sustained focus on conceptually driven photography books stemming from his travels in New England, the Hebrides, France, Italy, Egypt, and Ghana. (This latter period lasted more than thirty years, beginning around 1943 with his application—subsequently denied-for a Guggenheim grant to fund what would eventually become the book Time in New England, a collaboration with Nancy Newhall. ${ }^{91}$ ) Both the content and the physical qualities of Photographs of Mexico suggest its critical place in Strand's evolving approach to photography, his politics, and his balance of the two.

Photographs of Mexico contains twenty images taken in Michoacán, Hidalgo, Mexico, Puebla, Oaxaca, and "possibly Tlaxcala." ${ }^{192}$ These pictures fall into three basic categories, interspersed throughout the portfolio: indigenous architecture in rural settings, with an emphasis on arches and doorways; portraits of native villagers, most taken surreptitiously with a prism lens; and close-ups of hand-carved religious sculpture, primarily of suffering Christ figures and one beautiful Virgin. Taken together, the photographs make up Strand's attempt to compile a portrait of Mexico, albeit one that

\footnotetext{
${ }^{88}$ Ibid., 370.

${ }^{89}$ One well-known example is Wall Street (1915), although Naomi Rosenblum points out that this and other works from the same era "represent intuitive rather than programmatic political responses to perceptions about the city's power structure." Rosenblum, "The Early Years," in Stange, Paul Strand: Essays on His Life and Work (New York: Aperture, 1990), 38.

${ }^{90}$ Krippner, "Traces, Images and Fictions," 374.

${ }^{91}$ Paul Strand, Time in New England (New York: Oxford University Press, 1950).

${ }^{92}$ Ware, "Photographs of Mexico, 1940," in Krippner, Paul Strand in Mexico, 269.
} 
elides many of the more complex realities of the country, including its urban centres, rising industrialization, and the entirety of its non-indigenous population. ${ }^{93}$ Both the attempt and, some would say, the failure to create through this selection and ordering of images a persuasive representation of contemporary Mexico as a whole, attest to a number of concerns in Strand's work at this time and throughout his career. His populist leanings coincided with his long-standing fascination with Edgar Lee Masters's poem cycle The Spoon River Anthology, in which the deceased inhabitants of an American village intone the details of their own variously tragic lives and fates. As Naomi Rosenblum notes, in the decades following Spoon River's publication in 1915, the book came to resonate with disenchanted city-dwellers like Strand, who began to look for an alternative way of life in the supposedly more "universal" and natural rural landscape and its inhabitants. ${ }^{94}$ Indeed, the last three decades of Strand's career were marked by his growing disgust not only with urban life, but also with the American political and cultural scene more generally, particularly with the onset of the McCarthy hearings in the early $1950 \mathrm{~s} .{ }^{95}$ Strand's developing outlook clearly shaped the concept and form of his books, which document communities as far afield as Europe and Africa—and influenced as well his permanent relocation to Orgeval, France in 1951—but one can also find early traces, as Rosenblum does, in his Mexican work. ${ }^{96}$ Some of the same approach that marked Strand's subsequent books, namely his attempts to capture the spirit and history of a people in part by photographing their surroundings, resonates in Photographs of Mexico's evocative juxtaposition of the natural and built rural landscape, the stoic, monumental faces of local inhabitants, and the powerful iconography of their religious artifacts. Even the oversimplification that belies this ostensibly "comprehensive portrait" ${ }^{97}$ can be seen as a characteristic thread running through much of Strand's work. Alan Trachtenberg's

\footnotetext{
${ }_{93}^{93}$ Krippner, "Traces, Images and Fictions," 370.

${ }^{94}$ Rosenblum, "The Early Years," 50.

${ }^{95}$ A few years earlier still, in 1947, the Photo League, of which Strand had long been a prominent membereven a "patron saint" — was blacklisted by Attorney General Tom C. Clark, along with a long roster of other supposedly subversive organizations. See Anne Tucker, "Strand as Mentor," in Stange, Paul Strand: Essays on His Life and Work, 123 and 132.

${ }^{96}$ Ibid., 51.

${ }^{97}$ Krippner, "Traces, Images and Fictions," 370.
} 
assertion that in his photographs one finds more often the "timeless and universal" than "the immediate, the contingent, the unsettled moment" ${ }^{\prime 98}$ seems borne out here. ${ }^{99}$

Some of the tensions in Strand's work also play out in the material qualities of both editions of Photographs of Mexico, which were printed as sumptuously rich, handvarnished photogravures, hand-pulled from steel-faced plates, the positives for which Strand produced himself, resulting in what many have cited as one of the pinnacle examples of gravure printing. ${ }^{100}$ Strand remarked later that the portfolio represented a deliberate attempt to make photographic reproductions that were aesthetically on par with the originals (in this case, platinum prints), and chose photogravure-despite the fact that by 1940 it was already losing ground to offset lithography — as the process he felt best able to fulfill this goal. ${ }^{101}$ Certainly by the time the portfolio was reprinted in 1967, photogravure was even more of a relic, and indeed the Photogravure and Color Company, which printed the 1940 edition, was no longer dealing in flat-plate hand gravure. Nonetheless, Strand was able to enlist the Brooklyn-based Anderson Lamb Company and its master printer Albert Delong to make new prints from the original plates, ${ }^{102}$ and, remarkably, even in an edition four times larger and twenty-seven years later, the results are arguably as fine as the first run. Such consistency at such high quality indicates a key difference between ink-based reproduction and photographic printing, and the consistency of Strand's own vision, as well as the dedication with which he pursued it. Even though the paper colour, texture, and weight vary slightly between the two editions of the portfolio, the effect is much less obvious than it likely would have been between,

\footnotetext{
${ }_{98}^{98}$ Alan Trachtenberg, "Introduction," in Stange, Paul Strand: Essays on His Life and Work, 6.

${ }^{99}$ On the other hand, Strand himself argued for the capacity of the specific to stand in for the universal. As he wrote in 1946, "One person who has been studied very deeply and penetratingly can become all persons." Cited in Mike Weaver, "Dynamic Realist," in Stange, Paul Strand: Essays on His Life and Work, 202.

${ }^{100}$ Richard Benson, "Print Making," in Stange, Paul Strand: Essays on His Life and Work, 107. Benson notes that it was highly unorthodox for a photographer to be involved in the printmaking process at this level.

101 Paul Strand, 1962 interview with Robert Katz, cited in Ware, "Photographs of Mexico, 1940," in Krippner, Paul Strand in Mexico, 270. The subscription form for the portfolio also emphasizes this point, noting that with these photogravures, Strand had "finally found a process which he is satisfied will retain the rich qualities that distinguish his original prints." See the 20 Photographs of Mexico subscription form, Paul Strand Collection, AG17:1/2, "Mexican Portfolio, 1940: Reviews, Brochure," Center for Creative Photography.

${ }^{102}$ Krippner, Paul Strand in Mexico, 266.
} 
for example, two different types of gelatin silver paper from 1940 and $1967 .{ }^{103}$

In his 1990 essay "Print Making," Richard Benson describes the trajectory of

Strand's photographic methods over the course of his career, and suggests that Strand saw his photographs not as "fine prints" per se, but as "visual means to an expressive end." 104 According to Benson, this meant that Strand often pursued less common or less convenient materials and processes_-including platinum and photogravure, as well as the surface varnish that he added to both ${ }^{105}$ — because they alone yielded the physical effects that he felt best served his images. ${ }^{106}$ Benson also remarks that at the end of his life, it was his books, rather than his prints, of which Strand seemed most proud. ${ }^{107}$ This last comment surely implies not only Strand's satisfaction with the results of ink-based reproduction, but the importance of these extended book projects in conveying his ideas.

In 1940, when Photographs of Mexico was published, Jerome Mellquist, an art critic writing for The New Republic, praised the portfolio for allowing greater access to Strand's work than had his "all-to-infrequent New York exhibitions." ${ }^{108}$ Curator Katherine Ware suggests that Strand's use of photogravure may thus have had a more politicized motivation as well: that of making a high-quality version of his work more broadly accessible than it had been through the sporadic and geographically limited exhibition of

\footnotetext{
${ }^{103}$ The warmer, slightly less textured paper used in the first edition does seem to contribute a greater smoothness of tone compared to the second edition, which appears slightly grainier. This might also be due in part to the varnish used on the first edition, which has yellowed somewhat with time, resulting in a slight darkening of the prints. Nonetheless, the differences are indeed subtle.

${ }^{104}$ Benson, "Print Making," 103-04.

${ }^{105} \mathrm{~A}$ hand-written note on the text folio in the Metropolitan Museum of Art's copy of Photographs of Mexico reads, "These photographs were sprayed with a nitro-cellulose lacquer from the Egyptian Lacquer Co. Information from Mr. Strand, $29^{\text {th }}$ Oct. 1940."

${ }^{106}$ Benson, "Print Making," 105-06.

107 Ibid., 108.

${ }^{108}$ Jerome Mellquist, "Paul Strand's Portfolio," The New Republic (November 4, 1940): 637. Also cited in Ware, "Photographs of Mexico, 1940," in Krippner, Paul Strand in Mexico, 270.
} 
original prints. ${ }^{109}$ This proposition, as Ware is quick to point out, is significantly complicated by the fact that at $\$ 15$ a copy in 1940, Photographs of Mexico was still rather a luxury item to the average American. ${ }^{110}$ That Strand sold many copies by advance subscription in order to fund the project also limited its potential dispersal to the general populace, ${ }^{111}$ although Krippner notes that several members of Mexico's intellectual and political elite counted among those subscribers, indicating that the portfolio was at least successful in crossing cultural borders, albeit in a highly limited way. ${ }^{112}$ Interestingly, when Ansel Adams published Portfolio One in 1948, charging \$100 for the set of twelve original gelatin silver prints, ${ }^{113}$ Strand, in a letter to Adams the following year, proclaimed himself "very disturbed," and expressed his grave concern about "the effect the price of [the portfolio] will have upon the whole problem of establishing a proper value for a photograph." He continued, "First it says: a little over $\$ 8$ apiece is a reasonable price and secondly it says that the photograph as an art work can be made in any quantity or at least in quantity." ${ }^{114}$ Adams's reply, which defended his price as well as his idea that "the essence of the photographic process is its reproducibility," finishes with the challenge: "I can't reconcile your definitely social attitudes with your equally definite exalted financial value applied to art. Explain sometime, please!"115 Strand seems not to have done so, and indeed the contradiction that Adams pinpoints is striking. One wonders if the crux for Strand really was the distinction between photomechanical reproduction and the original

\footnotetext{
${ }^{109}$ Strand was clearly impressed and energized by the reception of his exhibition of platinum prints at the Sala de Arte in Mexico City in 1933, noting the diversity and sheer number of visitors, and remarking that due to its location and the configuration of the exhibition space, "it became part of the street." See Calvin Tompkins, "Profile," in Paul Strand: Sixty Years of Photographs: Excerpts From His Correspondence, Interviews, and Other Documents (Millerton, NY: Aperture, 1976), 155. (Also cited in Ware, "Photographs of Mexico, 1940," in Krippner, Paul Strand in Mexico, 268-69.) On the other hand, Strand claimed in his first letter to Ansel Adams, written that same year, to have "little interest in exhibitions-because at the base they seem to be un-American-just a mean and meaningless affair; mean in that they exploit the artist to entertain the public free of charge-meaningless in that they seldom establish any standards." See Paul Strand and Ansel Adams: Native Land and Natural Scene, text by Mike Weaver and Anne Hammond (Tucson, AZ: Center for Creative Photography, University of Arizona, 1990), 56.

${ }^{110}$ Ware, "Photographs of Mexico, 1940," in Krippner, Paul Strand in Mexico, 270.

111 Ibid.

112 Krippner, "Traces, Images and Fictions," 360.

${ }^{113}$ Accounting for inflation, Strand's earlier portfolio price of \$15 in 1940 would still translate to only \$25 in 1948 , for nearly twice as many prints.

114 Paul Strand and Ansel Adams: Native Land and Natural Scene, 76-77.

115 Ibid., 77.
} 
photograph, despite the fact that he had laboured expressly to make reproductions that could stand up to his originals. Strand's own portfolio was priced at less than a dollar per print, and so barring a radical change of opinion in the intervening eight years between his and Adams's portfolios, perhaps the explanation for at least part of the quandary rests here.

Meanwhile, the portfolio's use of photomechanical printing meant that nearly three decades later, following his second trip to Mexico in 1966, Strand was able to publish his much larger second edition, and indeed it is the 1967 version that one finds most often in museum collections as well as in photography auctions. Of course, in 1967 Strand had the support of the Aperture Foundation, and the expanded edition size in conjunction with the much higher purchase price (even accounting for inflation) suggests that the motivations for this second printing were perhaps as commercial as they were ostensibly populist, at least on the part of Strand's backers. The change in title from Photographs of Mexico to The Mexican Portfolio might also be an early hint at the imminent tide of marketable luxury portfolios, and it is surely no coincidence that Aperture was responsible for, among other publications, the four retrospective portfolios produced, "at the urging of friends," at the very end of Strand's life. ${ }^{116}$ At the very least, it seems worth noting that the 1967 example was supervised by Aperture and published by Da Capo Press; and that the 1940 edition was self-published and funded by Strand's wife, and that the idea for a portfolio was originally proposed by Lee Strasberg of the Group Theatre, whose 1935 course in theatre direction was instrumental in Strand's subsequent foray into socially concerned

\footnotetext{
${ }^{116}$ The third and fourth portfolio were finalized only after the photographer's death, in fact, and were signed by Hazel Strand "on her husband's behalf." All four portfolios—Portfolio 1: On My Doorstep, Portfolio 2: The Garden, Portfolio 3, and Portfolio 4-were printed by Richard Benson under Strand's supervision. See Paul Strand: The Limited Edition Prints (New York: Aperture Foundation, n.d. [1981?]). Despite the jump in price between the first and second editions of the Mexican portfolio, both pale in comparison to the $\$ 12,000$ price at issuance of the 1976 On My Doorstep. Meanwhile, in 2010, a mint-condition copy of The Mexican Portfolio sold at auction for \$2,000 USD, while a copy of On My Doorstep sold in 2011 for $\$ 10,000$ USD. Thus although the large edition size and photomechanical printing of the former may account for its relatively low price in today's market, its value overall has risen since its publication, whereas that of the all-but-posthumous 1976 production has apparently dropped, at least in this instance. See Swann Auction Galleries, Important Photographs \& Photobooks (New York, October 19, 2010), lot 116; and Sotheby's, Photographs (New York, October 5, 2011), lot 59.
} 
film work. $^{117}$

Ware suggests, and this is borne out by Strand's career, that portfolios were not to be his ultimate vehicle for the dissemination of his work, but the Mexican portfolio nonetheless stands at a significant crossroads in his exploration of printing techniques and physical formats. ${ }^{118}$ The structure of the portfolio itself has been explored in depth by both Ware and Krippner, who draw parallels between Strand's careful ordering of the images and his ongoing work in film during this period. ${ }^{119}$ Krippner draws attention to the way that each image responds to the ones that precede and follow it, drawing clear connections between the architectural images (which function not unlike establishing shots in film) and the people who might inhabit those spaces, and between those people and the poignant religious sculptures with which they are interspersed. ${ }^{120}$ Ware meanwhile notes the cinematic close-ups suggested by Strand's sequencing ${ }^{121}$ and, I would add, by the varying sizes of the prints themselves. She also emphasizes the physical interactivity of the portfolio format, which requires more viewer involvement than a film does, and creates a more "ceremonial atmosphere" than either a film or a book. ${ }^{122}$ Ultimately, books superseded both portfolios and films as Strand's medium of choice, but Photographs of Mexico may be seen as his first full-fledged attempt to compile a sequence of images to make up a larger, coherent whole. Strand himself was well aware of the cinematic qualities of his photographic sequences, noting in a 1965 interview with Nathan Lyons that "these books could probably not have happened if I hadn't spent ten

\footnotetext{
117 Ware, "Photographs of Mexico, 1940" in Krippner, Paul Strand in Mexico, 270; William Alexander, "Paul Strand as Filmmaker, 1933-1942," in Stange, Paul Strand: Essays on His Life and Work, 152. An odd note about Photographs of Mexico is that the title on the portfolio case is actually preceded by the number one: 1. Photographs of Mexico. In addition, the marketing materials issued for the portfolio in 1940 include the notation "First Edition." (Reproduced in Krippner, Paul Strand in Mexico, 48.) I have seen no mention that in 1940 Strand planned either additional portfolios or subsequent editions, so the inclusion of these details seems obscure.

${ }^{118}$ Ware, Ibid., 273.

${ }^{119}$ While the images in Photographs of Mexico were taken prior to Strand's work on Redes, the actual production of the portfolio came afterwards, in the midst of his ten-year period spent primarily as a filmmaker.

${ }^{120}$ Krippner, Paul Strand in Mexico, 45-49.

${ }^{121}$ Ware, "Photographs of Mexico, 1940" in Krippner, Paul Strand in Mexico, 270.

${ }^{122}$ Ibid.
} 
years as a filmmaker." 123

In both editions of the portfolio, we see a synthesis, however precarious, of a whole range of Strand's sometimes divergent political and artistic beliefs and concerns, a wrestling with form and function that marked his work for the entirety of his career. In the explanations for his use of photomechanical reproduction and his exchange with Ansel Adams about the question of reproducibility and price (which also drew in both Beaumont and Nancy Newhall ${ }^{124}$ ), we discover as well a window into the developing understanding of photography, and art photography in particular, at this time. There is a palpable concern about what makes photography an art worthy of serious consideration, as well as an evident consciousness of the very earliest stages of an actual market for such work. Many of these issues appear again in Ansel Adams's Portfolio One, discussed in the next chapter.

\footnotetext{
${ }^{123}$ Nathan Lyons, "From an Unpublished Interview with Paul Strand, 1965," in Nathan Lyons: Selected Essays, Lectures, and Interviews, edited by Jessica McDonald (Austin: University of Texas Press, 2012), 118. At the close of this published excerpt, Lyons too draws a connection not only between Strand's film and book work, but with the earlier Mexican portfolio.

${ }^{124}$ Letters to Adams from both of the Newhalls make mention of this dispute just a few days after Adams's own exchange with Strand. See correspondence dated April 2, 1949 (from Beaumont) and April 4, 1949 (from Nancy) in the Beaumont and Nancy Newhall Collection, AG48:2, "Adams, Ansel, 1947-53," Center for Creative Photography.
} 


\subsection{Ansel Adams: Portfolio One (1948)}

\section{Catalogue}

PUBLISHED: San Francisco: Ansel Adams, 1948

EDITION: 75 copies, 10 copies made especially for E. Weyhe, New York City. Presumably these ten copies are included in the total of seventy-five. Adams's original prospectus for the portfolio actually proposes an edition of 100, to be "sold by subscription only (excepting 10 copies made for E. Weyhe, New York City)," and indeed his list of purchasers shows copies 1-10 as having been sold to E. Weyhe. ${ }^{125}$

COPY CONSULTED: Copy 25/75, George Eastman House, accession number 1981:1016:0001-0012.

CASE: White paper-covered four-flap case with black text and black cloth ties. Made by Perry Davis, San Francisco. Dimensions: 46 × 39.3 x 1.4 cm (18.1 x 15.5 x 0.55 in).

PRINTERS: Photographs printed by Ansel Adams. Portfolio text designed and printed by Grabhorn Press, San Francisco.

TEXT: Paper folio with title page, introduction by Ansel Adams, list of prints, and technical specifications. Four pages.

PRINTS: Twelve selenium-toned gelatin silver prints, dry-mounted onto mat board, $42 \mathrm{x}$ $34 \mathrm{~cm}$ (16.5 x $13.4 \mathrm{in})$. Each print signed on the recto mount, with portfolio stamp indicating print and portfolio number on the verso. Varying sizes between $12.1 \times 16.5 \mathrm{~cm}$ $(4.75 \times 6.5 \mathrm{in})$ and $19.1 \times 24.1 \mathrm{~cm}(7.5 \times 9.5 \mathrm{in})$ or the reverse.

1. Mount McKinley, Alaska. 1948.

2. Saguaro Cactus, Sunrise, Arizona. 1946.

3. Rapids Below Vernal Fall, Yosemite Valley. 1948.

4. Mormon Temple, Manti, Utah. 1948.

5. Vine and Rock, Island of Hawaii, T. H. 1948.

6. Refugio Beach, California. 1946.

7. The White Church, Hornitos, California. 1946.

8. Roots, Foster Gardens, Honolulu, T. H. 1948.

9. Oak Tree, Snow, Yosemite. 1948.

10. Trailside, Near Juneau, Alaska. 1948.

11. Alfred Stieglitz, An American Place, New York. 1938.

12. Clouds Above Golden Canyon, Death Valley, California. 1946.

\footnotetext{
${ }^{125} \mathrm{~A}$ copy of the prospectus and the purchasers list can be found in the Ansel Adams Archive, AG31:2:9:11, "Portfolio One, 1948-1951, 1955-1956," Center for Creative Photography. E. Weyhe is Erhard Weyhe, the founder of the Weyhe Gallery and bookstore, which specialized in art prints.
} 
REPRODUCTIONS: Due to copyright restrictions, illustrations of Portfolio One are not included in the electronic version of this thesis.

Reproductions of this portfolio can be found in The Portfolios of Ansel Adams, introduction by John Szarkowski (Boston: Little, Brown, 1977). 


\section{Commentary}

Ansel Adams's Portfolio One was privately published in 1948, in an edition of 75 copies. It contains twelve mounted selenium-toned gelatin silver prints, housed in a white four-flap portfolio case with black lettering and black ties, which also includes a folio of text designed and letterpress printed by the Grabhorn Press, San Francisco. The three components of this folio-a short statement by Adams, a numbered list of the prints, and a summary of technical details pertaining to the production and intended life of those prints - as well as the photographs themselves, are revealing as to Adams's attitudes both about the portfolio and about his work more generally.

Portfolio One was, in fact, Adams's second published portfolio, following Parmelian Prints of the High Sierras in 1927. ${ }^{126}$ Adams did not discount this earlier portfolio, published at the behest (and through the financial assistance) of San Francisco philanthropist and art collector Albert Bender, but felt that it represented a less fully realized stage of his work, in "character and emphasis" ${ }^{\prime 127}$ as well as technically. ${ }^{128}$ Indeed, Parmelian Prints looks entirely distinct from its successors, from the black portfolio case with its gold-coloured satin lining, to the photographs themselves, printed on Kodak Vitava Athena Parchment T, a creamy and very thin, slightly translucent matte paper. ${ }^{129}$ Even more revealing is the very use of the word "parmelian," a faux-Greek term concocted by the portfolio's publisher, Jean Chambers Moore, out of fear that the word "photograph" would discourage potential buyers; an affectation that Adams quickly dropped from his subsequent endeavors.

Portfolio One was published some twenty-one years later, by which time Adams's

\footnotetext{
${ }^{126}$ A copy of Parmelian Prints resides at George Eastman House as well, accession number 1981:1015:01-5 and 1981:1015:07-18 (print six is missing). Prior even to Parmelian Prints, in 1923 Adams also compiled an inexpensive portfolio of forty-five prints ("they weren't very good") for members of the Sierra Club. See Ansel Adams and Ruth Teiser, Conversations with Ansel Adams: Oral History Transcript/1972-1975 (Berkeley, CA: University of California, 1978), 266.

${ }^{127}$ This is Adams's own phrase, from his preface to The Portfolios of Ansel Adams, introduction by John Szarkowski (Boston: Little, Brown, 1977), v.

${ }^{128}$ Adams remarked later that much less was known at the time about darkroom chemistry, and that his prints from before 1930 were not up to the processing standards he would later develop. See Adams, Oral History, 97.

${ }^{129}$ Images of all eighteen plates of this portfolio, plus a facsimile case, can be found in Photographs by Ansel Adams From a California Collection (New York: Christie's, April 11, 2008), lot 1003.
} 
approach to photography had largely crystallized, thanks in no small part to his 1933 meeting with Alfred Stieglitz, who remained an enthusiastic supporter and friend thereafter. Adams, for his part, counted Stieglitz as among his most important influences, and the older photographer's approbation did a great deal to buoy his confidence in his own work and approach. It was Stieglitz's death in 1946 that served as Adams's impetus to take up the portfolio format again, resulting in the production of Portfolio One, whose text includes a memorial dedication.

The portfolio's sequence of photographs, which date from 1946 to 1948, begins with Mount McKinley, Alaska (1948, plate 1), the only representative of the characteristically sweeping mountain vistas for which Adams is best known. The other photographs are more varied, from the monumental image of a saguaro cactus (1946, plate 2), and the towering white austerity of a Mormon temple (1948, plate 4), to the quiet study of moisture-beaded vegetation growing trailside in Juneau (1948, plate 10). The penultimate photograph in the portfolio is the only one taken before 1946, a contemplative 1938 portrait of Stieglitz bent over a desk in his gallery, framed by an open doorway and bathed in window light (plate 11). The final image, Clouds Above Golden Canyon, Death Valley, California (1946, plate 12), calls to mind one of Stieglitz's own early Equivalents, a fan of wispy cloud stretching high above a dark mountain ridge. Adams noted on more than one occasion that the selection of photographs for this portfolio in particular was highly subjective, and that each was an attempt to represent some intuitive aspect of his feeling for Stieglitz, a process of interpretation on which he professed an inability to elaborate further. ${ }^{130}$

The introductory text that accompanies the portfolio is a somewhat florid reiteration of the project's dedication to Stieglitz, in which Adams recalls Stieglitz's notion that art "is the affirmation of life," and insists that "a true photograph need not be explained, nor can be contained in words." ${ }^{131}$ The final page of the folio, meanwhile, lays out in detail the technical specifications of the photographs themselves, listing the sizes of the negatives, the film, paper, and toner used, as well as the developing chemistry. The

\footnotetext{
${ }^{130}$ Tom Cooper and Paul Hill, "Interview: Ansel Adams," Camera 55, no. 1 (1976), 38.

131 Portfolio One (San Francisco: Ansel Adams, 1948).
} 
text further counsels the owner of the portfolio as to the correct procedures for storage, care, and display — prints being exhibited should be shown behind glass, owners should consult a professional if the dry-mounting comes loose, and so on-and, notably, warns that "the 12 prints herein should not be separately disposed of." 132 This last admonition is especially telling, for although Adams would have been well aware that the prints in a portfolio could be easily divided up or re-sold, and indeed the folio notes indicate his expectation that at least some might be framed separately, it is clear that the conceptual unity of the portfolio as a whole was significant enough to include such a stipulation against its dissolution.

The juxtaposition of these three bodies of information within the text, while quite standard for a limited edition portfolio (if rather heavy on the technical details), also reflects much of the substance of Adams's work and his attitudes about photography. Certainly, it has been frequently remarked that Adams's photographic style and philosophy did not evolve much after moving away from his early Pictorialist-tinged period of the 1920s, and even in his own day he was sometimes criticized for clinging to what were characterized as precious and outmoded ideals concerning subject matter and the primacy of the fine print. The curator John Szarkowski noted in his 1977 introduction to The Portfolios of Ansel Adams that Adams's photographs were "perhaps the last confident and deeply felt pictures of their tradition," which is to say the heroic and idealizing American landscape tradition, whose roots lay at least as far back as the nineteenth century. ${ }^{133}$ Be that as it may, Adams's popularization of the technical and aesthetic understanding of and appreciation for the original photographic print is of no small historical significance. ${ }^{134}$ Furthermore, in his own work, the pursuit of the perfect print was of the utmost expressive importance. As Szarkowski explains it in his text, much

\footnotetext{
132 Ibid. The entire text for Portfolio One (as well as Two through Seven) may also be found in The Portfolios of Ansel Adams.

${ }^{133}$ Szarkowski, The Portfolios of Ansel Adams, xii.

${ }^{134}$ Adams published a number of influential technical manuals throughout his career, including Camera \& Lens (New York: Morgan and Lester, 1948), The Negative (New York: Morgan and Lester, 1948), and The Print (New York: Morgan and Lester, 1950), as well as his later book Examples: The Making of 40 Photographs (New York: Little, Brown, 1983), in which he described the making of forty of his best-known images.
} 
of the visual and emotional impact of Adams's work depends on the virtuoso depiction of subtle variations of natural light, and for this reason his apparently inexhaustible devotion to the flawlessly made gelatin silver print was an inextricable part of his art. ${ }^{135}$ To his credit, Adams recognized that his particular brand of fine printing was not necessarily for everyone, ${ }^{136}$ but in keeping with A. D. Coleman's argument discussed previously, it is important to consider this material aspect of Adams's work on its own terms. Thus the folio's extensive description of the photographs' technical details and high-flown introductory statement are both entirely in keeping with Adams's personal interests and working philosophy.

It must be recognized as well that Adams was able to work so extensively with portfolios-whose edition sizes ranged from seventy-five copies for Portfolio One, to 260 copies for Portfolio Four-because he was unusually successful at selling his work, thanks in large part to the financial backing of patrons such as Albert Bender and David McAlpin, the critical support of such notables as Stieglitz, along with Nancy and Beaumont Newhall, and his later lucrative partnerships with William Turnage, who became his manager in 1971; Robert Feldman, proprietor of Parasol Press; and gallerist Harry Lunn. ${ }^{137}$ These close business relationships taught Adams a great deal about the notion of editioning prints and its relationship to market value. He went so far as to cancel (with a cheque punch) all of the negatives for Portfolio Five, Six, and Seven-the three published by Parasol Press, which also owned the reproduction rights to those photographs ${ }^{138}$ although this may have been a decision he regretted, and was one he never repeated. At the same time, Adams acknowledged that, with certain exceptions (such as Moonrise, Hernandez, New Mexico, which he did not edition, and of which he made hundreds of prints), the portfolio photographs were the ones he sold the most of, precisely because

\footnotetext{
135 Ibid., viii-ix.

${ }^{136}$ Adams, Oral History, 208.

137 Photography dealer Jill Quasha's 1980 MBA thesis offers a number of insights into the roles of Turnage, Feldman, and Lunn in developing several highly successful marketing strategies for Adams's work. See Jill Quasha, "The Emergence of Photography as a Business: An Important 'New' Collectible," MBA thesis (New York University, 1980), 4-10.

${ }^{138}$ Adams, Oral History, 269.
} 
they were printed from the outset in editions of seventy-five or more. ${ }^{139}$ Compare this, however, to Edward Weston, who briefly numbered his photographs in the 1930s, but never completed any of his projected editions of fifty prints and soon gave up the practice ${ }^{140}$; or to Berenice Abbott, discussed in the following section, who took nearly twenty years to complete the full edition of her Atget portfolio, owing primarily to a lack of funds and buyers.

Portfolio One is thus the first representative example of Adams's career-long engagement with the limited edition, original print portfolio, and stands as a concise and instructive summary of the photographer's own approach to his work. Adams's devotion to the interpretive fine print, his Stieglitz-influenced belief in the photograph as an emotional, even spiritual equivalent to lived experience, and his canny relationship to the then-embryonic photography market are all evident in not only this particular portfolio, but in his continued use of the format over many decades. As one of the most influential twentieth-century advocates of photography as a serious art, Ansel Adams's adoption of the portfolio format is significant. The use of the portfolio to underscore photography's artistic and commercial viability, as well as its technical exactitude, is one of the central narratives in its history, particularly in the United States. Portfolios such as Portfolio One served as a template for waves of ambitious photographers (not to mention the galleries and dealers) who followed, as well as, in some instances, a standard against which to rebel.

\footnotetext{
139 Ibid., 534.

${ }^{140}$ Amy Conger, Edward Weston: Photographs (Tucson: Center for Creative Photography, University of Arizona, 1992), 24.
} 


\subsection{Berenice Abbott: 20 Photographs by Eugène Atget 1856-1927 (1956)}

\section{Catalogue}

PUBLISHED: New York: Berenice Abbott, 1956

EDITION: 100 copies

COPIES CONSULTED: Copy 4/100, Metropolitan Museum of Art, accession number 56.610; Copy 10/100, George Eastman House, accession number 1976:0109:0001-0020.

CASE: Gray/green cloth-covered four-flap case with ATGET stamped in gold foil on recto cover. Dimensions: $34.9 \times 25.4 \times 2.1 \mathrm{~cm}(13.7 \times 10 \times 0.8$ in $)$.

TEXT: Printed folio of text with title page, colophon, introduction by Abbott, and numbered list of plate titles.

PRINTER: Printed by Berenice Abbott

PRINTS: Twenty gold-toned gelatin silver prints, dry-mounted onto mat board, $23.1 \times 23.3$ $\mathrm{cm}(9.1 \times 9.2 \mathrm{in})$. Each print stamped in black ink on verso mount. Prints approximately $22.7 \times 17.0 \mathrm{~cm}(9.0 \times 6.5 \mathrm{in})$ or the reverse.

The following titles are Abbott's, as they appear in the portfolio, followed in square brackets by more precise designations, including Atget's negative numbers, where available. This information comes primarily from John Szarkowski and Maria Morris Hambourg, The Work of Atget, Vol. 1-4 (New York: Museum of Modern Art, 1981-1985), with the exception of the following: plate 11 from Peter Barberie, Looking at Atget (Philadelphia, PA: Philadelphia Museum of Art, 2005); plates 4 and 5 from Molly Nesbit, Atget's Seven Albums (New Haven and London: Yale University Press, 1992); plates 17 and 19 from Maria Morris Hambourg "Eugène Atget, 1857-1927: The Structure of the Work," PhD Diss. (Columbia University, 1980); and plate 20 from the Museum of Modern Art collections database.

1. St. Cloud [Saint-Cloud (1915-1919), LD:780]

2. 'Nenuphars' [Nénuphars (Before 1900), LD:835]

3. Men's Fashions [Magasin, avenue des Gobelins (1925), PP:83]

4. Eclipse, 1911 [Pendant L'Eclipse-17 avril 1912-Place de la Bastille, PP:335, formerly LD:891]

5. Paris Interior [Intérieur d'un ouvrier, Rue de Romainville (1910), 742]

6. 'Pompe Funebre ( $1^{\mathrm{e}}$ Class),' 1910 [Pompes funèbres (1910), ve:19]

7. Carrousel [Foire (1923), PP:29]

8. 'Marchand Abat-Jours' [Marchand abat-jours (1899-1900), PP:3196]

9. 'Rue St. Rustique,' March 1922 [AP:6313]

10. Maison Close [Versailles, femme et soldat, maison close. Mai 1921, PP:17] 
11. Bar de Cabaret [Marchand de vin, 15 rue Boyer (1910-11), PP:261]

12. Street Paver [Paveurs (1899-1900), PP:3221]

13. 'Cour, Rue de Valence' [Cour, 7 rue de Valence. Juin 1922, AP:6379]

14. Ragpickers' Hut [Villa d'un chiffonier (1912), PP:347]

15. Mannequin [Avenue des Gobelins (1927), PP:158]

16. Street Musicians [Joueur d'orgue (1898-99), PP:360, formerly PP:3124]

17. 'Boucherie, Rue Christine' [(1923-24) PP:34]

18. 'Faucheurs, Somme' [Flancheur (Somme) (before 1900), LD:858]

19. Environs of Paris [Saint-Cloud (May 1922) LD:1108]

20. 'Masque Antique' [Undated, CO:54]

REPRODUCTIONS: The reproductions that follow are courtesy of George Eastman House. 

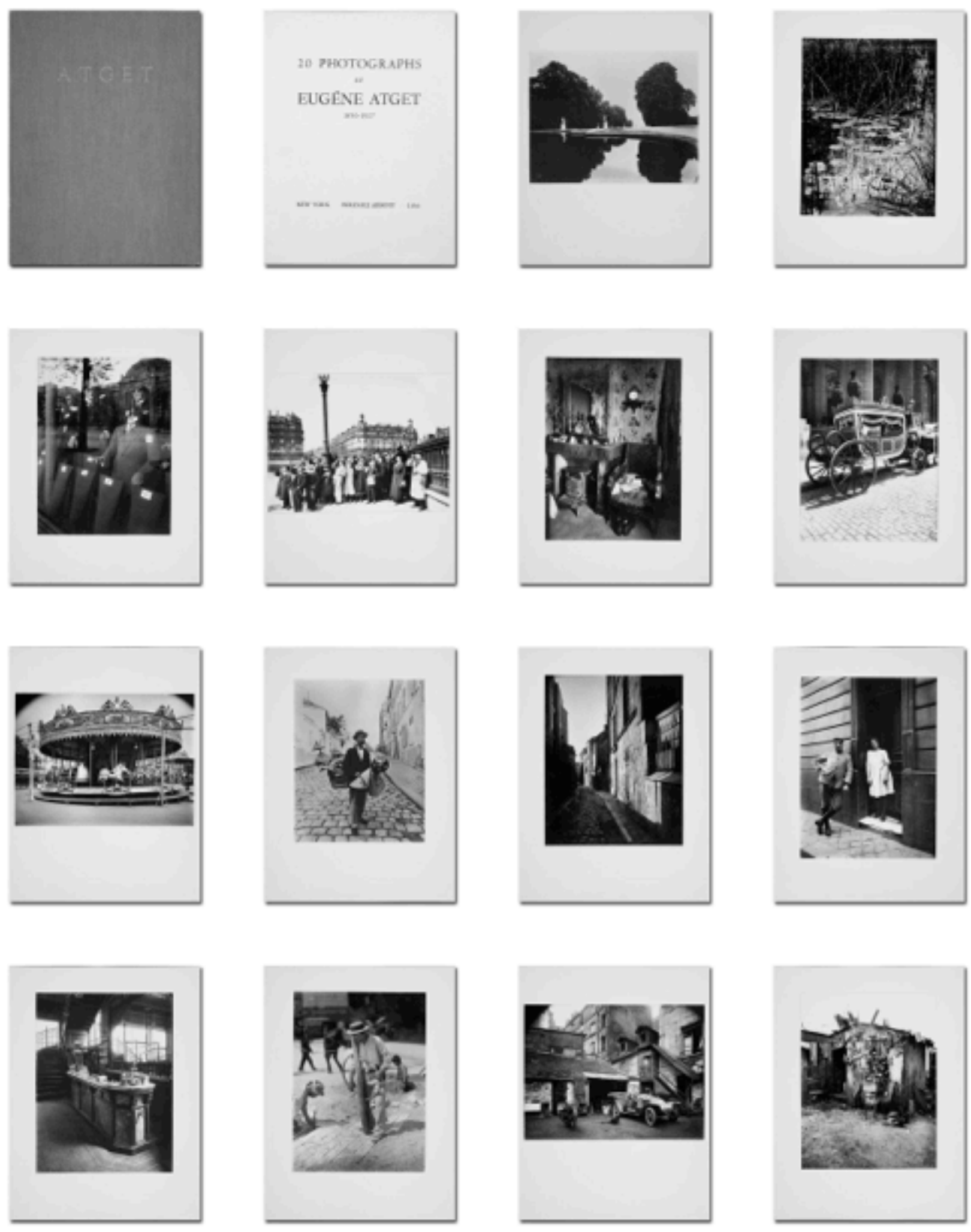

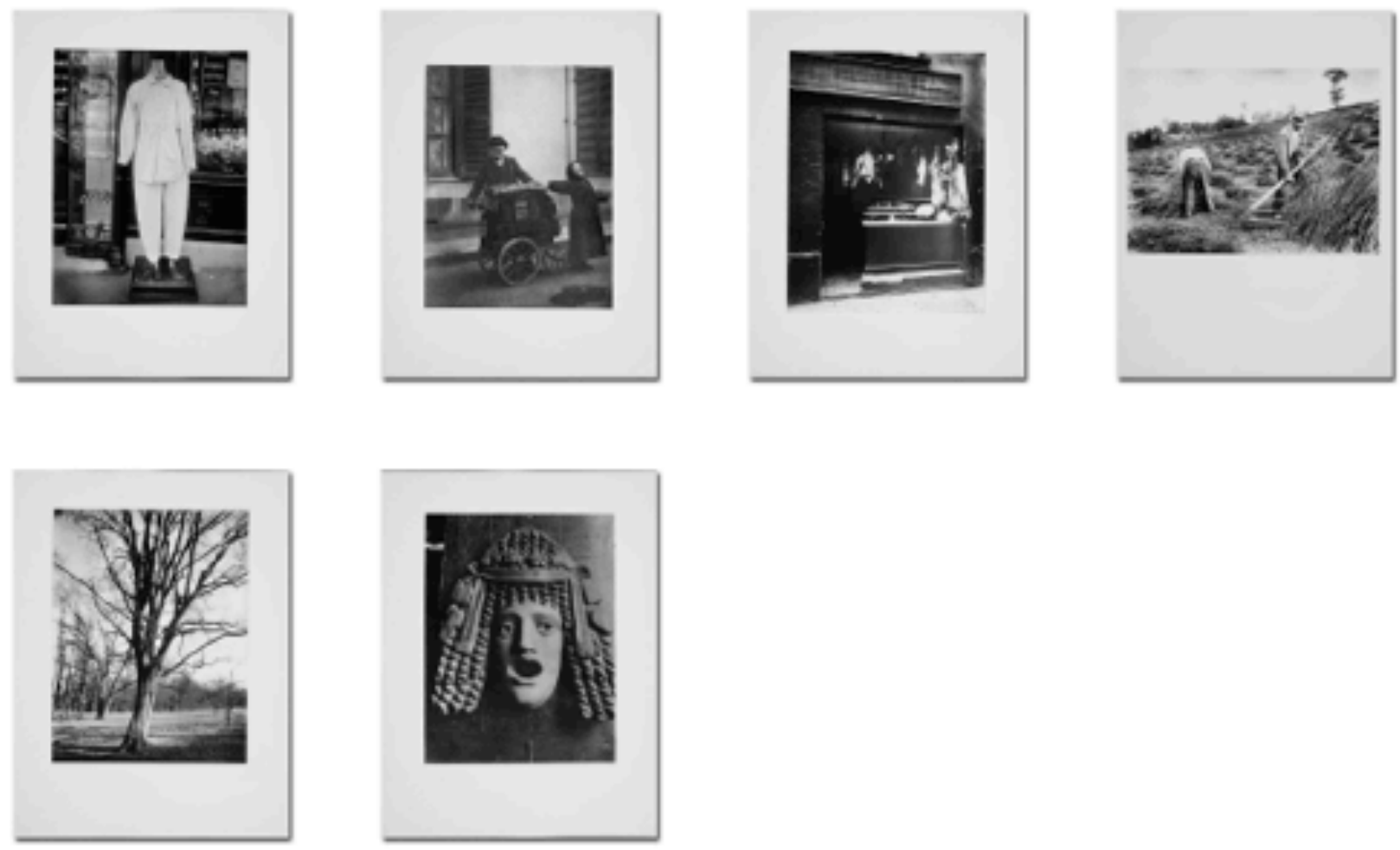


\section{Commentary}

Although Ansel Adams's Portfolio One was likely one of the models on which Berenice Abbott based the physical construction and marketing of her 1956 portfolio 20 Photographs by Eugène Atget 1856-1927, ${ }^{141}$ in the details of their intent and execution the two endeavors are in fact strikingly different. Published in an edition of one hundred, Atget contains twenty gold-toned gelatin silver prints made posthumously by Abbott from a selection of Atget's original glass negatives, which she chose from among the 1,300 in her collection of his work. Like many portfolios, including those by Adams, the Atget portfolio was intended to make money and promote the work of its subject. As a posthumous undertaking, moreover, it might be superficially linked to, or seen as a precursor of, the rising tide of other such posthumous portfolios produced by galleries, dealers, and estates in subsequent decades to accommodate and profit from the market's growing thirst for photography. At closer range, however, Abbott's Atget portfolio stands apart as a singular and complex entity, albeit one very much shaped by its photographic and cultural milieu.

The story of Berenice Abbott's involvement with and promotion of Atget is by now firmly ensconced in the history of modern photography. ${ }^{142}$ In 1925 , as a young photographer in Paris, she was introduced to Atget's work by her employer Man Ray, and struck up a friendship with him over the next two years. Upon Atget's death in 1927, she sought out his friend and the executor of his estate, André Calmettes, and ultimately purchased the contents of Atget's studio, some 7,000 prints and 1,300 negatives. (This number did not include the 2621 negatives of Paris art and architecture sold by Atget in 1920 and an additional 2000, either sold or donated, by Calmettes to Le Service

\footnotetext{
${ }^{141}$ This and subsequent information, where cited, comes from Julia Van Haaften in an email to the author on May 21, 2013, which included sections of Van Haaften's yet-untitled biography of Berenice Abbott, currently in progress. I am most grateful for her generosity in making this material available to me. ${ }^{142}$ This story is recounted in, among various other sources, Peter Barberie's essay in Looking at Atget (Philadelphia, PA: Philadelphia Museum of Art, 2005).
} 
photographique des Monuments historiques in 1927. ${ }^{143}$ ) Julien Levy, the New York art dealer, Surrealism aficionado, and fellow enthusiast of Atget's work, provided additional funds a few years later, in $1930 .{ }^{144}$ After her return to New York in 1929, Abbott spent much of the next four decades working tirelessly to promote Atget's legacy through exhibitions, articles and books, and through the sale of prints, both vintage photographs from her collection and new prints that she made from Atget's negatives. In 1968, after years of looking unsuccessfully for a suitable and willing home for her Atget collection, she finally sold it to the Museum of Modern Art in New York.

Abbott first began making and selling reprints from Atget's negatives in 1930, initially for an exhibition of Atget's work at the Weyhe Gallery in New York, where Julien Levy was then employed, to coincide with the publication of her book Atget: Photographe de Paris. ${ }^{145}$ She continued to print from Atget's negatives over the next four decades, often exhibiting and selling the reprints alongside Atget's original photographs at galleries including the Julien Levy Gallery, Limelight, and the Witkin Gallery, with varying degrees of success.

Abbott announced the publication of her Atget portfolio in April of 1956, but its production was significantly complicated by a perpetual lack of funds and the difficulty of securing paper suitable for printing Atget's glass negatives. She first offered the portfolio for sale by subscription at a discounted price, and sold thirty copies from this initial announcement. ${ }^{146}$ Printing these copies took her through November of the following year, and only a dozen additional copies out of the projected edition of one hundred were sold by the end of the 1950s. ${ }^{147}$ Abbott continued to print the portfolio in fits and starts throughout the next decade, appealing to various collectors and dealers to sell copies. By

\footnotetext{
${ }^{143}$ Maria Morris Hambourg, "A Biography of Eugène Atget," in Szarkowski and Hambourg, The Art of Old Paris (New York: Museum of Modern Art, 1982), 29-31.

${ }^{144}$ Barberie, Looking at Atget, 58.

${ }^{145} \mathrm{Ibid}$. Abbott's book is Atget: Photographe de Paris, preface by Pierre Mac-Orlan (Paris: Henri Jonquières, 1930).

${ }^{146}$ Van Haaften, email to the author.

${ }^{147}$ The portfolios in the collection at the Metropolitan Museum of Art and George Eastman House, the copies to which I referred when writing this paper, are numbers 4 and 10, respectively, and were thus two of those purchased in response to Abbott's subscription offer in 1956. Van Haaften confirms this in her manuscript, although she notes that the Met purchased their copy at full price.
} 
1973, however, forty-six copies of the portfolio remained unprinted, until Robert Feldman, the print and photography dealer and proprietor of Parasol Press, ${ }^{148}$ offered money down for Abbott to print the remainder of the edition, which he would then sell. ${ }^{149}$ By early 1974 , almost twenty years after its inception, the full run was complete. ${ }^{150}$

The eloquence of Abbott's Atget portfolio as a physical object stems largely from its selection of images and from some of the specific choices that informed the production of the photographs. Since Atget first entered the public eye as a photographer worthy of attention—and not simply as the self-effacing producer of documents pour artistes ${ }^{151}$ much energy has been spent attempting to determine just how to understand and contextualize his work. The paucity of direct information about his life and the intentions behind his photographs, coupled with the almost unparalleled fervor and curiosity his images have provoked for nearly a century, has given rise to constantly shifting interpretations of his sprawling and enigmatic body of work. This, in turn, has led writers as diverse as John Szarkowski, ${ }^{152}$ Abigail Solomon-Godeau, ${ }^{153}$ and Peter Barberie ${ }^{154}$ to consider the evolution of these readings of Atget as a significant historical thread in and of itself. When Abbott selected the twenty images in the portfolio from the large cache of negatives she owned, it was her attempt to summarize the photographic oeuvre as she understood it, and as she hoped it would be best appreciated by a larger public. Included are examples of Atget's shop windows, small tradesmen, ragpickers, domestic interiors,

\footnotetext{
${ }^{148}$ Parasol Press also published Ansel Adams's Portfolio Five, Six, and Seven, in 1970, 1974, and 1976, respectively.

${ }^{149}$ Van Haaften, email to the author.

${ }^{150}$ The question of when and how Abbott printed the portfolios, especially in the years after 1968, when she sold her Atget collection to MoMA, has been the subject of some confusion. See Clark Worswick, Berenice Abbott, Eugène Atget (Santa Fe, NM: Arena Editions, 2002), 38. Van Haaften suggests that Abbott may have been working from copy negatives, possibly from the beginning of the project, and notes that she had been concerned for decades about the potential deterioration of Atget's original glass plates.

${ }^{151}$ Documents pour artistes appeared on the sign on Atget's studio door, as a means of advertising his work. See Berenice Abbott, The World of Atget (New York: Horizon Press, 1964), viii.

152 John Szarkowski, "Understandings of Atget," in Szarkowski and Hambourg, Modern Times (New York: Museum of Modern Art, 1985), 9-33.

${ }^{153}$ Abigail Solomon-Godeau, "Canon Fodder: Authoring Eugène Atget." In Solomon-Godeau, Photography at the Dock: Essays on Photographic History, Institutions, and Practices (Minneapolis: University of Minnesota Press, 1991), 28-51. Previously published in Print Collector's Newsletter 17, no. 2 (JanuaryFebruary 1986): 221-27.

${ }^{154}$ Barberie, Looking at Atget.
} 
street scenes, and trees. The photograph once selected to grace the 1926 cover of La Révolution surréaliste (titled Eclipse in the portfolio) is included as well. Abbott would not, at that time, have understood the significance of the complex numbering system by which Atget organized his photographs, deciphered decades later by Maria Morris Hambourg, ${ }^{155}$ and indeed Abbott tried in many cases to obscure Atget's negative numbers in the final portfolio prints. From the relatively privileged vantage point of the twenty-first century, the portfolio serves perhaps less as an instructive overview of Atget's work, and more as a window into Abbott's particular view of that work, coloured by her abiding belief in its power and her dedication to garnering public attention for its importance, as well as marked by the inevitable lacunae in her knowledge of its scope and its organizing principles. The portfolio thus stands alongside Abbott's other publications in contributing, one might say, to our understanding of her understanding of Atget's work. ${ }^{156}$

The decision to print Atget's negatives using modern gelatin silver papers rather than the albumen papers he favoured during his lifetime was, of course, an unavoidable necessity. Abbott and Levy apparently worked together to try to approximate the look of Atget's original prints, but with limited success. Although Peter Barberie notes that the Abbott reprints in the collection of the Philadelphia Museum of Art (acquired from the estate of Julien Levy), many dating back to the 1930s, vary significantly in tone and paper quality, ${ }^{157}$ the photographs in the George Eastman House and Metropolitan Museum of Art copies of the Atget portfolio are quite neutral in colour and look unmistakably like what

\footnotetext{
${ }^{155}$ Hambourg, "The Structure of the Work." It is further explained in her PhD dissertation, "Eugène Atget, 1857-1927: The Structure of the Work" (Columbia University, 1980).

${ }^{156}$ Prior to Atget: Photographe de Paris in 1930, Abbott published several articles, including "Eugène Atget," Creative Art 5 (September 1929), 651-56; "Photographer as Artist," Art Front 16 (September-October 1936), 4-7, reprinted in Julia Van Haaften, Berenice Abbott Photographer: A Modern Vision (New York: The New York Public Library, 1989), 12-15; "Eugène Atget, Forerunner of Modern Photography," U.S. Camera 1, no. 12 (Autumn 1940): 20-23, 48-49, 76, and 1, no. 13 (Winter 1940): 68-71; and "Eugène Atget," The Complete Photographer 6, no. 6 (1941), 353-59, Reprinted in The Encyclopedia of Photography, vol. 1 (New York: Educational Alliance, 1943; reprinted New York: Greystone, 1963), 335-39. Subsequently, Abbott also published the book The World of Atget (New York: Horizon Press, 1964).

${ }^{157}$ Barberie, Looking at Atget, 63-64.
} 
they are: rather high-contrast gelatin silver prints from the 1950s. ${ }^{158}$ When Abbott first published the portfolio, the response to its print quality was mixed. In his 1957 review of the portfolio for Image, Minor White complained that "contemporary prints of [Atget's] negatives are doomed to shortcomings from the start." ${ }^{159}$ A. Hyatt Mayor, curator of prints at the Metropolitan Museum of Art, was apparently much more encouraging. ${ }^{160}$ Meanwhile Helen Gee, who in late 1956 staged a successful Atget exhibition at her New York gallery, Limelight that included both original photographs and Abbott's reprints, felt that Abbott's prints lacked the warmth of the originals, but later wrote "it didn't matter whether the prints were by Atget or Abbott. People bought images, not rarity or namesthe word vintage was used primarily for wine." ${ }^{161}$ In our own time, Clark Worswick has taken pains to emphasize that the reprints stand as tokens of a long and rich relationship between one photographer and another, as well as of a particular moment in the history of photography. ${ }^{162}$ With this in mind, and given Abbott's own significance as a photographer and printer, it is telling that since the days of the Atget show at the Limelight, the market has shifted such as to overwhelmingly prioritize the vintage Atget prints over the laterand yet by now vintage in their own right-reprints by Abbott.

Berenice Abbott's Atget portfolio, then, stands in some ways as a precursor to the posthumous portfolios of later decades, but is distinguished by the complex circumstances of its making and the perhaps historically unparalleled relationship of its maker with its subject. The agonized trajectory of its physical production over so many years, particularly when compared with the creation and sale-at once carefully orchestrated and seemingly effortless - of Ansel Adams's portfolios tells another story about the ongoing development of the twentieth-century photography market, including the rise and fall of galleries,

\footnotetext{
${ }^{158}$ It is entirely possible that variations also exist between different copies of the portfolio, given the extended time span over which it was printed. For example, a later copy, number 64 (held in a private collection in France), displays Atget's characteristic darkened top corners in its print of Eclipse, the result of an interaction between his old-fashioned brass lens and the elevated camera angle. In the George Eastman House copy, number 10, these corners appear to have been burned in to blend with the light tones of the sky.

${ }^{159}$ Minor White, "Atget, A Portfolio," Image 6, no. 2 (February 1957): 46.

${ }^{160}$ Van Haaften, email to the author.

${ }^{161}$ Gee, Limelight, 194.

${ }^{162}$ Worswick, Abbott and Atget, 30-31.
} 
presses, and dealers, as well as about Abbott's own fraught relationship with that market and its participants. Finally, the aesthetic decisions that inform the Atget portfolio as a material object are indicative of Abbott's understanding of the work she was reproducing, and about her hopes for its acceptance into the developing history of the medium. 


\subsection{Lee Friedlander and Jim Dine: Photographs \& Etchings (1969) \\ Catalogue}

PUBLISHED: London: Petersburg Press, 1969

EDITION: 75 plus 15 artist's proofs

COPY CONSULTED: Copy 74/75, National Gallery of Canada, accession number 17040.1-19.

CASE: Black leatherette box, made by Rudolf Rieser, Cologne.

TEXT: Title page, colophon sheet, both etched by Dine. One sheet with dry-mounted photograph by Friedlander of the two artists, and a preface etched by Dine.

PRINTERS: Photographs by Lee Friedlander in New York, etchings by Jim Dine in Amsterdam.

PRINTS: Seventeen gelatin silver photographs (including double portrait) by Friedlander, sixteen etchings by Dine. Each sheet contains one photograph (dry-mounted on etching paper) and one etching. Etchings vary between $9.5 \mathrm{~cm}(3.74 \mathrm{in})$ and $21.0 \mathrm{~cm}(8.27 \mathrm{in})$ on the short side, and $19.1 \mathrm{~cm}(7.52 \mathrm{in})$ and $74.9 \mathrm{~cm}$ (29.49 in) on the long side. Photograph dimensions vary between $17.5 \mathrm{~cm}(6.87 \mathrm{in})$ and $27.3 \mathrm{~cm}$ (10.75 in) on the long side, and $11.7 \mathrm{~cm}(4.63 \mathrm{in})$ and $17.5 \mathrm{~cm}(6.87 \mathrm{in})$ on the short side. Sheets measure $75.6 \times 45.7 \mathrm{~cm}$ (29.75 x $18.0 \mathrm{in})$.

Titles, dates, and order of photographs are not given in the portfolio itself, but have been obtained, along with additional catalogue information, from Peter Galassi, Friedlander (New York: The Museum of Modern Art, 2005), 445. All etchings are untitled, and the photographs are as follows:

Frontispiece: London. 1967 (double portrait of the artist and photographer)

1. White Plains, New York. 1966.

2. Chicago, Illinois. 1968.

3. Denver, Colorado. 1965.

4. New York City. 1968.

5. Syracuse, New York. 1968.

6. Colorado. 1967.

7. New York City. 1968.

8. Minneapolis, Minnesota. 1968.

9. Madison, Wisconsin. 1966.

10. South Carolina. 1968.

11. Binghampton, New York. 1967. 
12. Baltimore, Maryland. 1962.

13. Blaze Starr, Baltimore, Maryland. 1968.

14. New York City. 1967.

15. New Orleans, Louisiana. 1968.

16. Los Angeles. 1960s.

REPRODUCTIONS: Due to copyright restrictions, illustrations of Photographs \& Etchings are not included in the electronic version of this thesis.

Small reproductions may be viewed in the online collection of the Art Institute of Chicago, last accessed June 27, 2013:

http://www.artic.edu/aic/collections/artwork-

search/results/all/title\%3A\%22photographs+and+etchings\%22 100. 


\section{Commentary}

Photographs \& Etchings, published in 1969, is a collaborative portfolio by photographer Lee Friedlander and the artist-frequently but not quite accurately classified as a Pop artist - Jim Dine. Friedlander met Dine in 1963 when the latter, then living in New York, purchased one of his TV still lifes (apparently Friedlander's first print sale) after seeing it published in Harper's Bazaar. ${ }^{163}$ When the two decided to collaborate a few years later, Dine was living in England. By way of negotiating the cross-Atlantic divide, each artist sent eight selections of his work for the other to match with prints of his own. The result is a set of sixteen sheets with Dine's etchings printed on the right, and Friedlander's gelatin silver photographs mounted on the left, both in black and white. The portfolio also includes a sheet bearing Friedlander's double portrait of the two artists and an introductory text by Dine, describing their mutual affinity ("Our work is from the same house. He always understands my words") and etched in his distinctive calligraphic scrawl; as well as a sheet of publishing information and a title page, printed in the same style. The whole is housed in a black paper-covered box, and was published simultaneously in a trade edition book as Work From the Same House by Trigram Press, London. ${ }^{164}$ Dine's etchings represent an array of his characteristic motifs-tools, bathrobe, lips, hearts, and a variety of sexually suggestive abstractions-while Friedlander's photographs mostly, though not exclusively, showcase his typically offbeat street scenes, with their sly juxtapositions and collage-like window reflections.

The portfolio and the book are both Friedlander's first, and thus mark significant milestones for a photographer who has continued to be an enthusiastic adherent to both

\footnotetext{
163 Galassi, Friedlander, 39.

${ }^{164}$ Both Trigram Press and the Petersburg Press, which published the portfolio, also published additional work by Dine in the same year. See Jim Dine, Vegetables (New York: Petersburg Press, 1969), a portfolio of eight prints; and Jim Dine, Welcome Home Lovebirds (London: Trigram Press, 1969), a collection of poems. A humourously stricken letter from Trigram proprietor Asa Beneviste to Dine in March of that year complains of Friedlander's long list of stipulations for faithfully reproducing his photographs, and wonders if the book will ever get past the proofing stage. See the Trigram Press Archive, Box 4, folder 1, University Libraries, Special Collections, Washington University in St. Louis.
} 
formats throughout his career. It is also, however, his only foray into this kind of joint project with another artist. Although, as already discussed, nearly all book and portfolio projects are inherently group efforts, Photographs \& Etchings is particular in that its actual contents are also collaborative, and unusual for the fact that this collaboration took place across worlds, as it were. As Peter Galassi points out, in 1969 the art world had not yet come around to photography, despite the fact that its concerns for the past decade, which included an omnivorous interest in —-to borrow the art critic John Russell's words"breaking down and re-designing the traditional boundaries of art,"165 might theoretically have made such inclusion obvious. ${ }^{166}$ This portfolio thus seems emblematic of the general spirit of the time, yet stands alone as a unique example of its kind.

In his own practice, however, Dine frequently supplemented the vigor and spontaneity of his printmaking with an avidity for collaborating, apparently energized by the process of working with other people. In 1970, Russell described Dine's collaborations as "free-floating affairs, parallel adventures that maintain contact with one another without actually touching," ${ }^{\prime 167}$ a characterization that seems to aptly describe the easy rapport between Dine's bawdy, spirited etchings and Friedlander's drily humourous and sometimes enigmatic photographs. Dine's collaborative style may well have been a natural match for Friedlander's own working method, which is marked by an intuitiveness and athleticism that belie its underlying intelligence. In subject matter too, there is a clear sympathy, as everyday scenes and commonplace objects are seen anew and pressed into the service of concerns both formal and personal.

Despite the fact that Friedlander has chosen most often to present his work in book form, he has also continued to make portfolios throughout his career. Nor has he seemed able to leave well enough alone when it comes to the books themselves, often producing limited editions or alternate versions of his trade publications, book works that stretch the limits of the format, including examples comprised of original prints $(A-Z, 1-10,1993)$, or others bound in novel ways so that they might be taken apart at the owner's discretion

\footnotetext{
165 John Russell, "Jim Dine and the Idea of the Print," London Magazine 10, no. 2 (May 1970), 46.

166 "Artists were escaping from the studio into the street," Galassi writes, "but photography, needless to say, was already there." Galassi, Friedlander, 40.

${ }^{167}$ Russell, "Jim Dine and the Idea of the Print," 54.
} 
(The American Monument, 1976). ${ }^{168}$

Photographs \& Etchings, on the other hand, seems to suffer somewhat when adapted to book form. The paired works, marked by playfulness and camaraderie when given room to breathe on the spacious portfolio sheets, feel cramped by the narrower confines of the book. Certain of Dine's etchings have been rearranged or roughly abbreviated, presumably to fit into the limited space of the page. In the portfolio, no order is prescribed for the sheets, but the book by its nature dictates a sequence. In other works this might be part of its appeal, but in this case it seems to eliminate a certain spontaneity and flexibility generated by the seemingly random compilation of loose sheets. In a material sense too, something seems lost in the translation from portfolio to book. The tension between the glossy surface and continuous tone of the gelatin silver prints, and the tactile three-dimensionality of the etchings, whose rich black lines bite deeply into the thick handmade paper, is diluted by the flat uniformity of offset lithography and the sheen of the coated paper in the trade edition.

Despite this, however, the fact that Photographs \& Etchings was also published as a book seems fortuitous, and certainly Friedlander has found ample room in both formats to showcase the myriad and evolving qualities of his work. Most important, perhaps, is simply the fact that Friedlander has turned so often to these apparatuses, highlighting his work's intrinsic relationship to multiplicity in both content and form-that is, the dynamic, layered qualities of the photographs themselves, and his propensity for presenting them in groups. What curator Joel Smith calls Friedlander's sense of the "irreducibility of the world to an isolated statement" ${ }^{169}$ is compellingly underscored by his continuing fascination with both the portfolio and the book, and his refusal to respect the boundaries of either.

\footnotetext{
${ }^{168} A-Z, 1-10$ (New York: Haywire Press, 1993) is a two-volume book, housed in a slipcase and printed in an edition of ten copies, which contains original gelatin silver photographs printed on thin "thesis-weight" paper. A copy is held in the collection of the Canadian Centre for Architecture, Montreal, accession numbers PH1994:0013.01:001-026 and PH1994:0013.02:001-010. The images in this book also appear in Letters to the People (New York: D.A.P., 1993). (See Galassi, Friedlander, 454-456.) The American Monument (New York: The Eakins Press Foundation, 1976) was published in three limited editions of decreasing size and increasingly fine materials, but all are assembled with a screw-post binding that allows the reader, at least in theory, to disassemble and reassemble the book, and remove or re-order prints. (See Galassi, Friedlander, 446-447.)

${ }^{169}$ Joel Smith, "More than One: Sources of Serialism," in Joel Smith, ed., More than One: Photographs in Sequence (Princeton, NJ: Princeton University Art Museum, 2008), 19.
} 


\subsection{Les Krims: The Deerslayers, The Little People of America 1971, and The Incredible Case of the Stack $O^{\prime}$ Wheats Murders (1972)}

\section{Catalogue}

PUBLISHED: Buffalo, NY: Les Krims, 1972 (all portfolios)

EDITION: 4000 copies (each portfolio)

COPY CONSULTED: The Deerslayers, copy 1441/4000; Little People, copy 1659/4000; Stack O'Wheats, copy 1154/4000, all Ryerson Image Centre, no accession numbers.

CASE: Blue paper-covered clamshell boxes, each bearing a sticker on the lid with a representative photograph and the portfolio title. Dimensions: $14.9 \times 13.5 \times 1.5 \mathrm{~cm}(5.9 \times$ $5.3 \times 0.6$ in).

TEXT: Each portfolio contains a printed introduction, which also includes information about the corresponding deluxe portfolio edition. The introduction to The Deerslayers was written by Alex J. Sweetman; Little People, by A. D. Coleman; Stack O'Wheats, by Robert A. Sobieszek.

PRINTERS: Thorner-Sidney Press, Buffalo, New York.

PRINTS: The Deerslayers contains 23 photographs plus the cover image; Little People, 24 photographs plus the cover image; Stack O'Wheats, 10 photographs (the cover image is repeated from the portfolio). All images are printed in brown-toned offset lithography. Sheet dimensions (for all): $14.4 \times 12.8 \mathrm{~cm}(5.7 \times 5.0$ in). Image dimensions (for all): $12.5 \times$ $8.5 \mathrm{~cm}(4.9 \times 3.3 \mathrm{in})$ or the reverse. No image titles or sequence given for any of the portfolios.

REPRODUCTIONS: The reproductions that follow were taken at the Ryerson Image Centre. All images (C) Les Krims. 

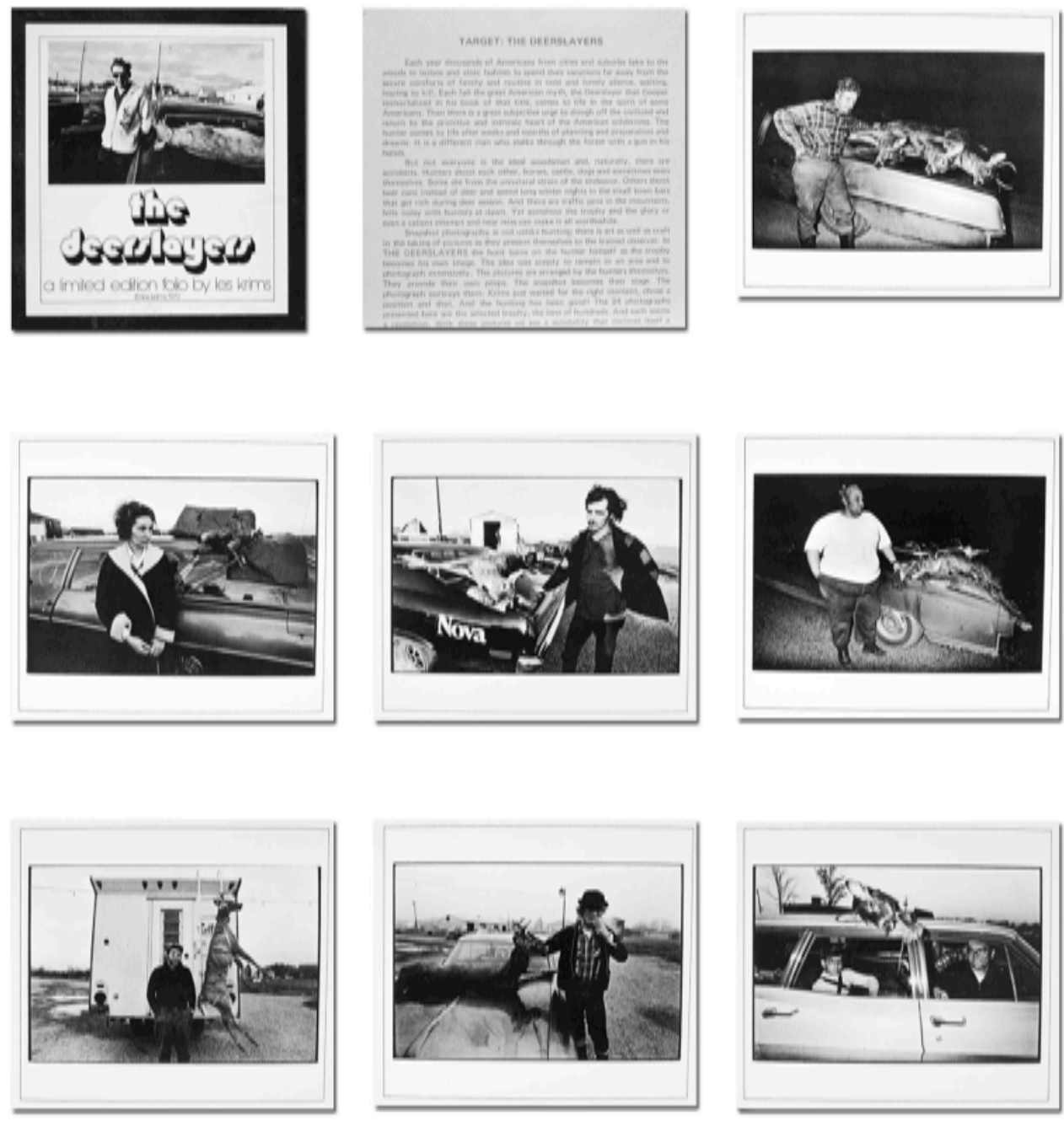

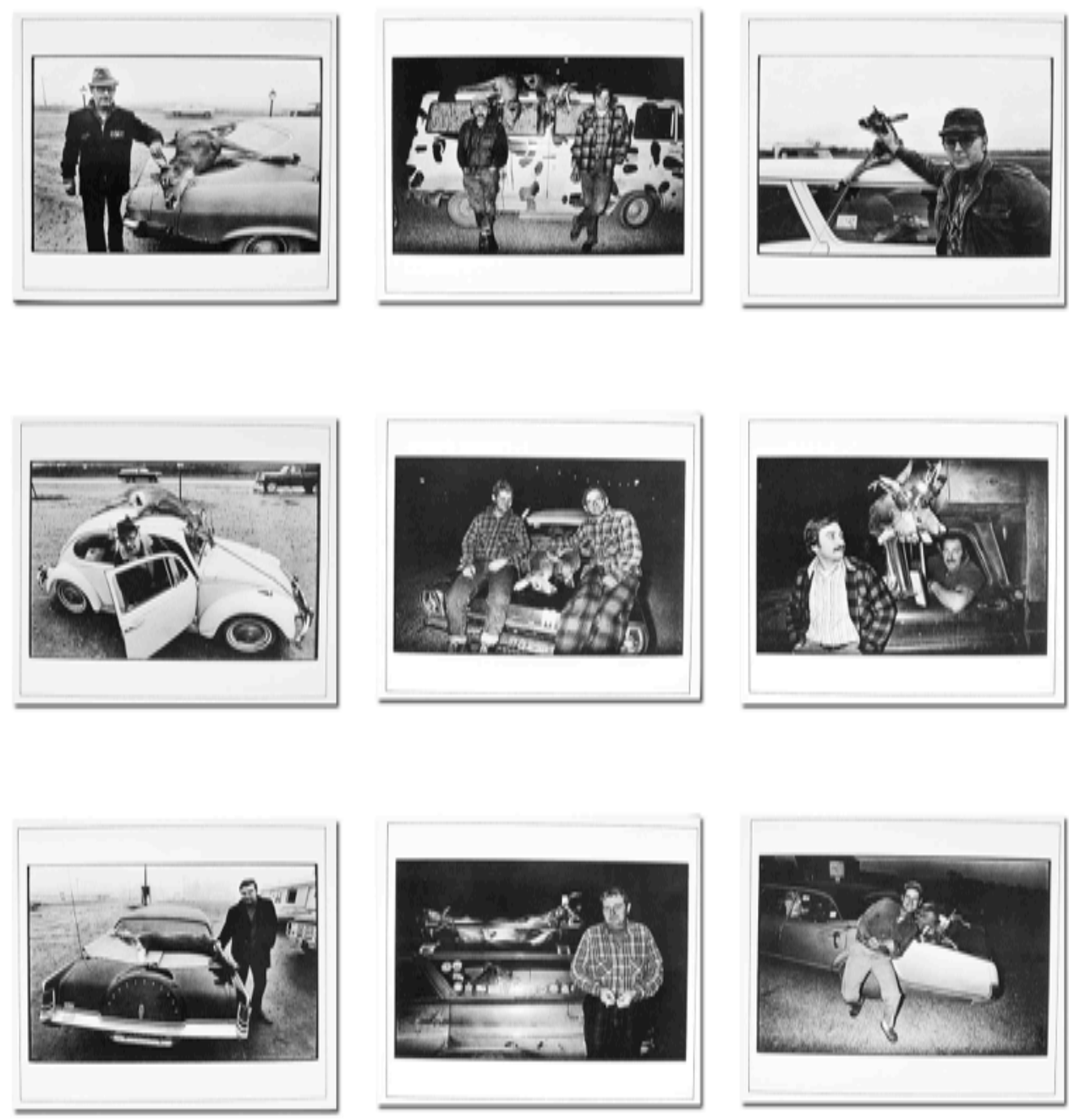

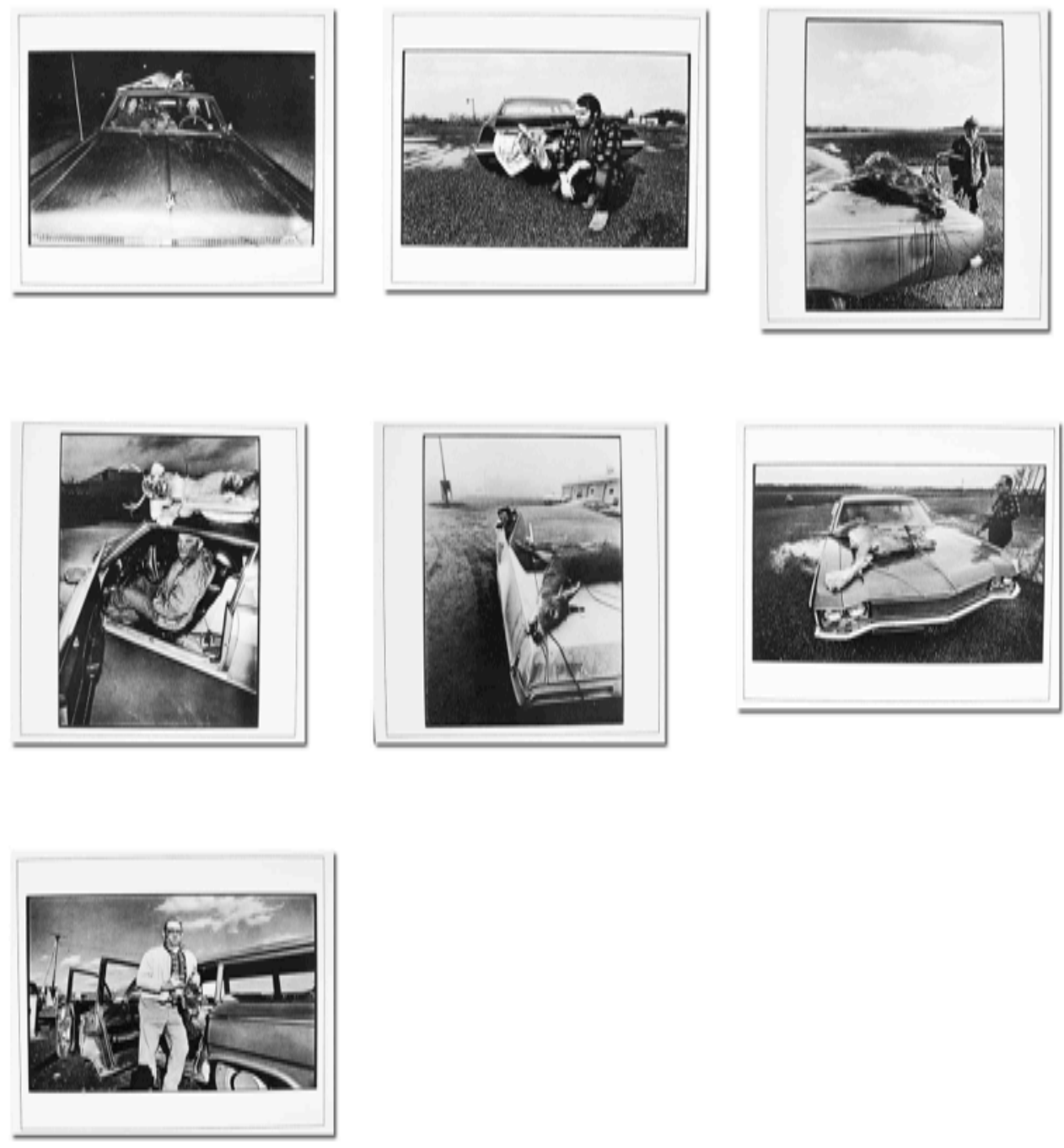

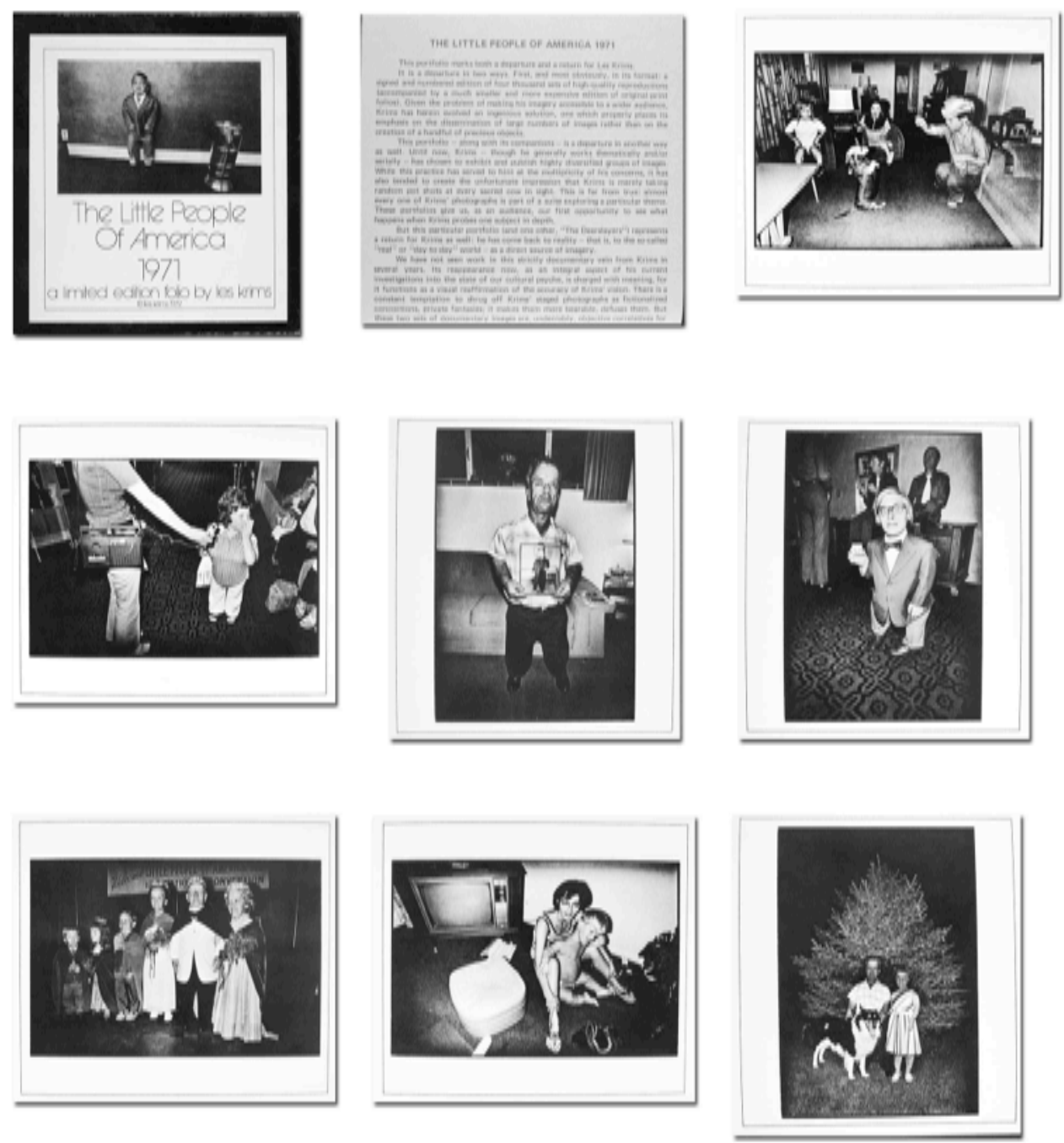

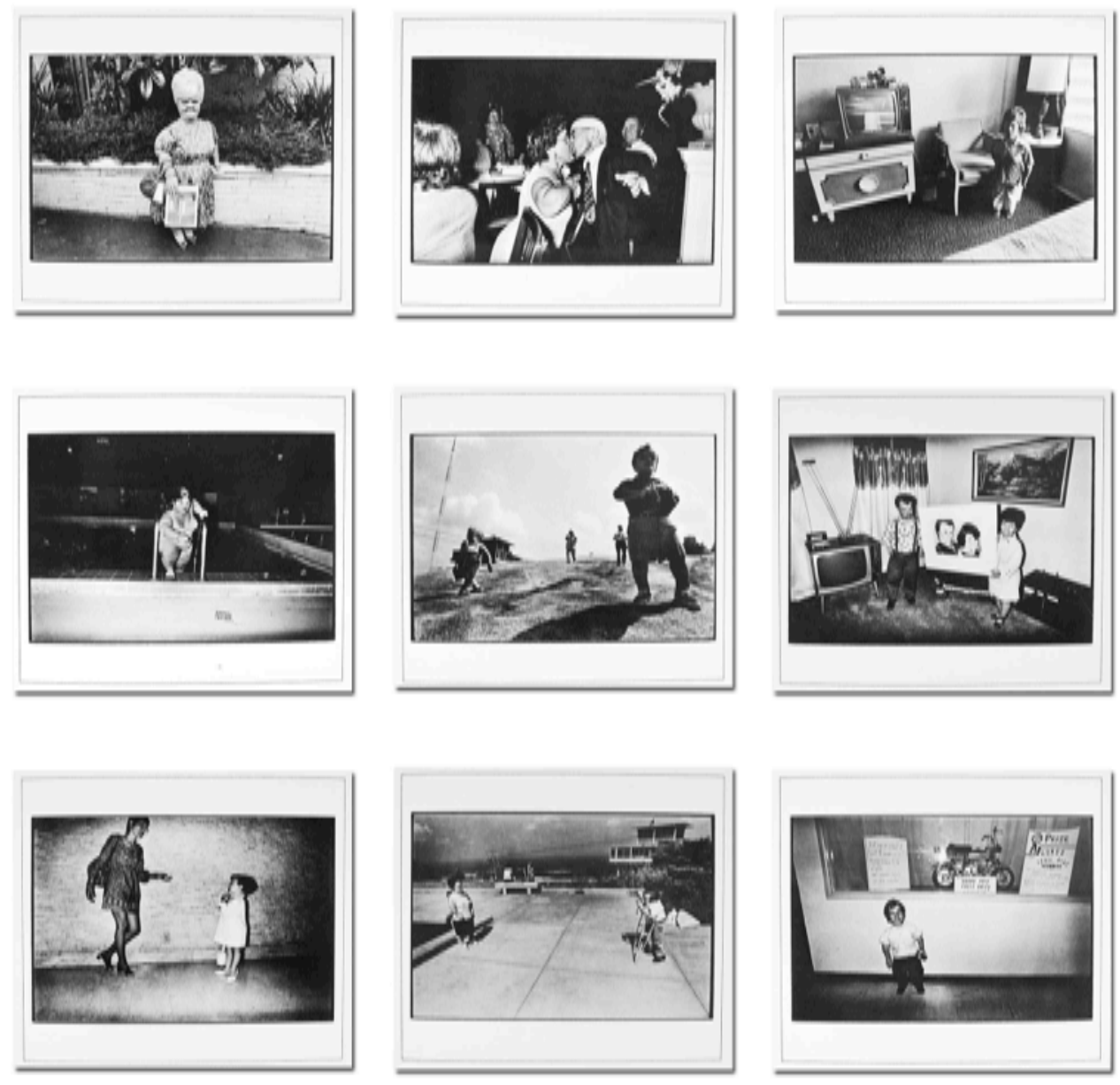

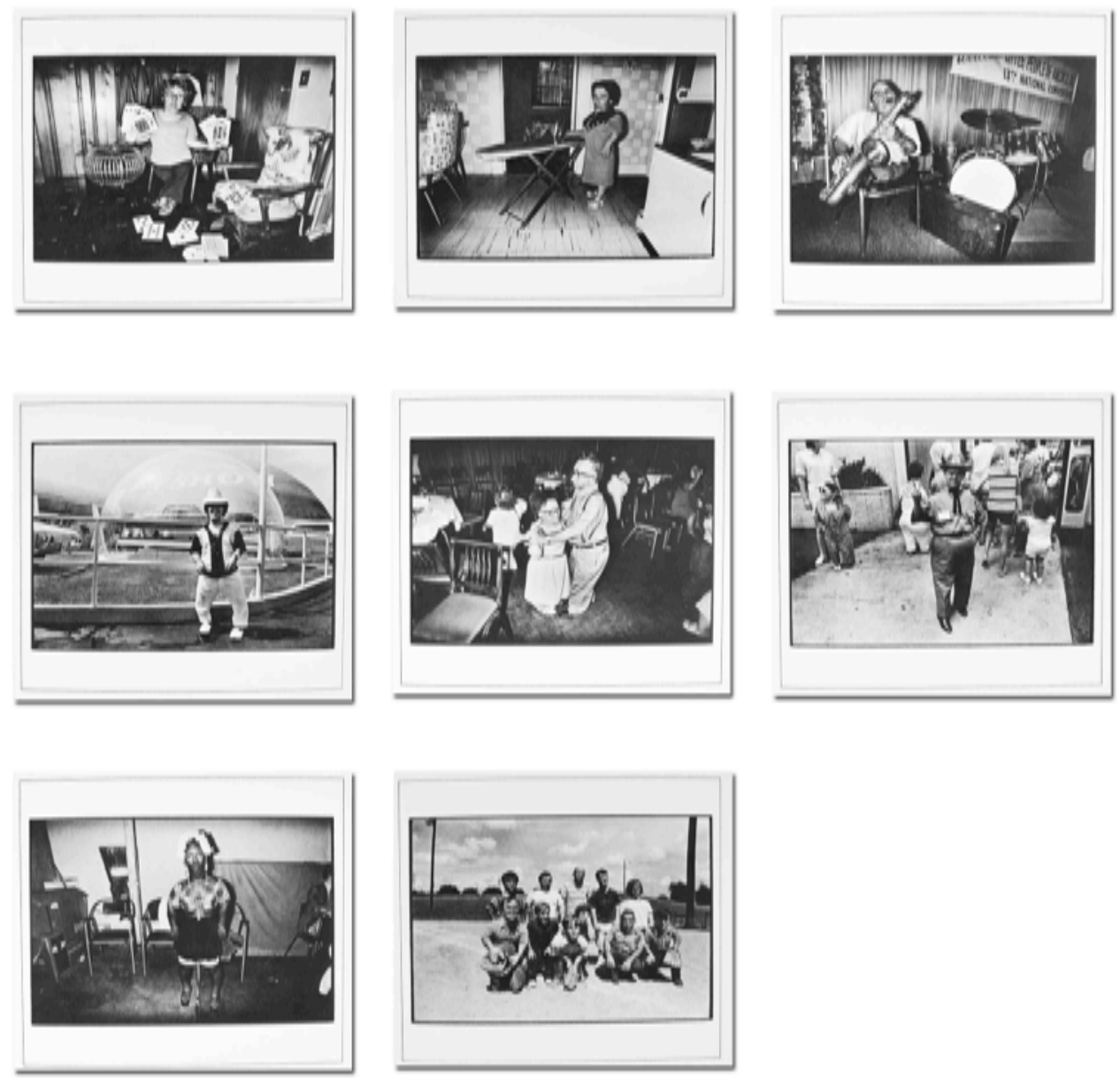

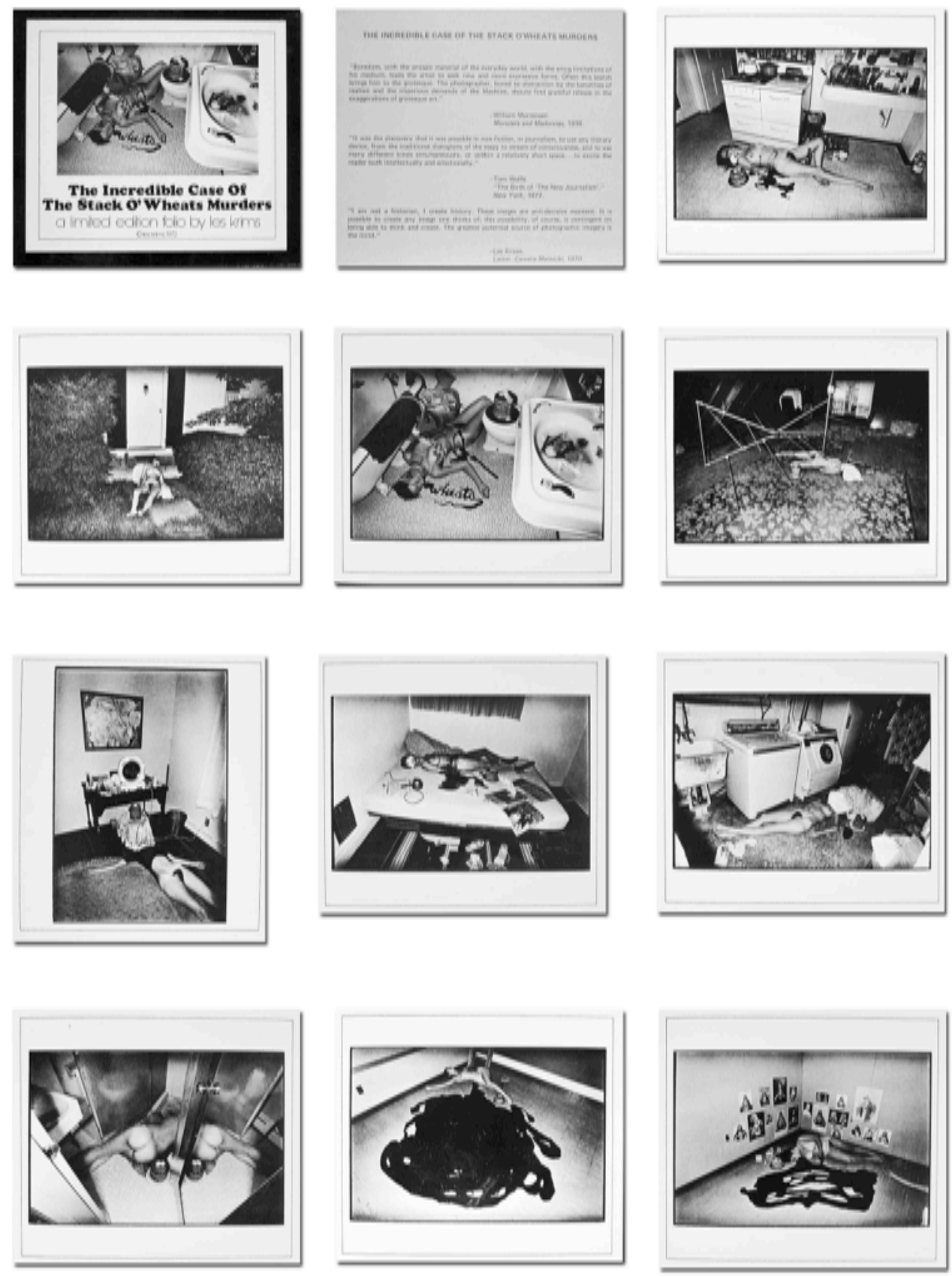


\section{Commentary}

While Paul Strand remarked in 1973 that "what exists outside the artist is much more important than his imagination," ${ }^{170}$ the work of Les Krims has long been predicated on nearly the opposite assumption. In explaining his photography to the editor of Camera Mainichi in 1970, Krims referred to his images as "fictions," a term he has returned to throughout his career, noting, "The greatest potential source of imagery is the mind." ${ }^{171}$ In 1972, he published three small offset-printed portfolios, each in an edition of 4000 copies: The Deerslayers, The Little People of America 1971, and The Incredible Case of the Stack $O^{\prime}$ Wheats Murders. These three portfolios were published simultaneously, even sharing the same press sheets, some of which were themselves editioned and exhibited at the Witkin Gallery in 1972, alongside twenty-five framed "single image" Kodalith prints. ${ }^{172}$ Taken together, the portfolios comprise an extended critique of what Krims saw as some of photography's hegemonic trends, and form what he has described as "a synthesis of methods and ideas-a fusion of the conceptual, candid, and commercial, which I believed would displace prevailing practice in art photography." ${ }^{173}$ In each portfolio, the images, none of which are titled or sequenced, are accompanied by a short essay (by artist and critic Alex Sweetman, critic A. D. Coleman, and George Eastman House curator Robert Sobieszek, respectively) that elucidates—and implicitly validates—-the underlying meaning of the work, as interpreted by each of the writers.

For The Deerslayers, Krims spent two hunting seasons (1970 and 1971) at a

\footnotetext{
170 Tompkins, "Profile," 15-35.

${ }^{171}$ Les Krims, "Leslie Krims: Portfolio," Camera Mainichi, no. 8 (August 1970): unnumbered introduction page.

172 Les Krims, "An Unpublished, Unvarnished Interview with a Conservative Artist," on the website of Les Krims (copyright 2006, accessed February 16, 2013). One of the signed press sheets, which contains twenty images taken from all three portfolios, is in the collection of the Ryerson Image Centre, accession number FP.1996.0004. It is copy 55/200.

${ }^{173}$ Krims, "An Unpublished, Unvarnished Interview with a Conservative Artist." While this online interview is relatively recent, Krims expressed similar ideas at least as early as his 1977 Kodak lecture, in which he stated that this triptych of portfolios summed up what his feelings were about the medium, and that they pointed to the direction he felt would be an important one in photography. ("Les Krims," 8 Photographic Perspectives: A Lecture Series on Photography [Ryerson University, Toronto, October 13, 1977]. CD.)
} 
roadside checkpoint in upstate New York, at which hunters stopped to allow their deer to be examined by officials from a state conservation department. ${ }^{174}$ In each of the portfolio's twenty-four photographs, a hunter poses with his (or in one case, her) kill, having chosen both his or her own position and that of the deer strapped to the hunter's car (itself a form of display required by law, but interpreted with a degree of creative license by each hunter). The series is intended to put forward a tongue-in-cheek notion of hunters as "conceptual artists making sculpture,"175 as well as to undercut expectations about the fictitious nature of Krims's own work by presenting candid photographs-made in what Krims characterized as an "almost dumb and mechanical fashion" — that might misleadingly appear directed or staged. ${ }^{176}$ The contrast between the rather extended parade of, some would say, distasteful images of dead animals, and the possibility of alternative realities-in a 1972 interview, Krims remarked that hunting restrictions too strictly enforced sometimes result paradoxically in animal deaths stemming from overpopulation-also serves to undermine an uncritical faith in photography as a transparent documentation of objective fact. ${ }^{177}$

The Little People of America 1971 contains twenty-five images taken by Krims in his capacity as the official photographer for the Little People of America (or LPA, still extant at the time of this writing), an organization for people with dwarfism. The photographs were taken at the 1971 LPA convention in Atlanta, Georgia, as well as at the homes of some of the group's members, and show their subjects in a range of everyday settings and circumstances. The concept of the portfolio was to make "a minority document to end minority documents, ${ }^{\prime 178}$ a proposition based in all seriousness, the underlying pun notwithstanding, on Krims's frustration with what he saw as the exploitative nature of "concerned" photography that turns the suffering of others (particularly the underprivileged) into fodder for images that play on the emotions but

\footnotetext{
${ }^{174}$ Les Krims, "'Can I Take Your Picture?' Interview with Les Krims," Afterimage I, no. 4 (November 1972): 2.

175 Krims, "An Unpublished, Unvarnished Interview."

${ }^{176}$ Krims, "Can I Take Your Photograph?," 2.

177 Ibid.

178 Ibid., 3.
} 
ultimately change nothing. ${ }^{179}$ In his 1982 examination of this portfolio, critic Terry Barrett calls some of the images empathetic, but characterizes others as cruel, suggesting that they are composed so as to create a heightened impression of grotesqueness. ${ }^{180}$ Krims himself has denied this supposed distortion both in his intention and in the images themselves, stressing his sense of responsibility toward his subjects (in this particular project), as well as the reportedly positive reception of the photographs by the LPA members who saw them. ${ }^{181}$ In his introduction to the portfolio, A. D. Coleman goes so far as to suggest that in fact the very element of satire in this work makes it democratic and "basically sympathetic," adding that "the least hint of a kid-gloves attitude" would be infinitely more insulting to those depicted. ${ }^{182}$ Indeed, whatever satire exists in Krims's LPA work seems far less intrusive or sharp-edged than, for example, Lee Friedlander's images of parties and singles bars, taken at almost exactly the same time. ${ }^{183}$

Finally, The Incredible Case of the Stack $O^{\prime}$ Wheats Murders sees Krims in a more characteristic "directorial mode" (to borrow Coleman's term), ${ }^{184}$ photographing fictional crime scenes in which domestic settings are the backdrop for ten prone nude women lying in outrageously copious pools of blood (really Hershey's chocolate, as revealed in Robert Sobieszek's portfolio's text), accompanied by stacks of buttered pancakes, the ostensible trademark of a heinous serial killer. Particularly when seen in conjunction with the other two portfolios, Krims's staged fictions once again offer a damning burlesque of photographic reportage, implicating the viewer in his or her delectation of violently prurient imagery, and underscoring the unreliable and often manipulative nature of seemingly factual photographs.

\footnotetext{
${ }^{179}$ Krims has referred to this kind of photography as "a despicable sport," pointing to the blithe advice, apparently offered by at least one photography magazine in the 1960s, to add one stop when photographing in the inner city. See Krims, "An Unpublished, Unvarnished Interview."

${ }^{180}$ Terry Barrett, "The Offset Work of Les Krims: An Interpretive Critique," Camera Lucida 5 (Winter 1982): 52.

${ }^{181}$ Krims, "Can I Take Your Picture?," 3-4.

${ }^{182}$ A. D. Coleman, introduction to The Little People of America 1971.

${ }^{183}$ These pictures, taken between 1968 and 1971, are, in the words of Peter Galassi, characterized by the "lampooning wit of Friedlander's gleeful misanthropy." They were exhibited as a slide show under the title Gatherings at MoMA in 1972, the same year that Krims's portfolios were published. See Galassi, Friedlander, 43 and $153-157$.

${ }^{184}$ A. D. Coleman, "The Directorial Mode: Notes Toward a Definition," in Light Readings, 246-257. Originally published in Artforum (September 1976).
} 
Despite the fact that Krims has always worked in thematic "idea groups," 185 the three offset portfolios were the first public representation of such extended explorations, and furthermore stand as an even larger cumulative whole when considered together. Krims has continued to produce portfolio and book works throughout his career, often publishing them himself (generally under his imprint, Humpy Press), as in the case of the books Making Chicken Soup and Fictcryptokrimsographs, and the portfolio Idiosyncratic Pictures. ${ }^{186}$ Significantly, one of the more pragmatic factors informing the offset production of Deerslayers, Little People, and Stack $O^{\prime}$ Wheats was to promote original print editions of the same portfolios. The introductory text of each offset portfolio describes the deluxe version, each of which includes additional artifacts such as, in the case of Stack $O^{\prime}$ Wheats, bags of chocolate syrup and pancake mix. ${ }^{187}$ The irony, perhaps, is that although Krims went so far as to commission specially made boxes for full editions of these portfolios, only one completed, boxed version was ever sold (to a private collector), with an additional unboxed set sold to the Maison Européenne de la Photographie, in Paris. ${ }^{188}$ According to Krims, there was, in 1972, no real way to distribute and sell the deluxe editions, although it is perhaps more accurate to suggest that he was unable to tap into the still newly fledged market. ${ }^{189}$ Krims in fact has begun or planned a number of other ambitious portfolio projects over the course of his career, most of which were never realized..$^{190}$ Meanwhile, the offset portfolios—which sold for \$3.95 USD, ${ }^{191}$ and which Krims also links to the vogue for inexpensive "multiples" in the contemporary art world more generally ${ }^{192}$-have been disseminated widely, remain readily accessible to this day, and can arguably be called Krims's best-known work.

\footnotetext{
${ }^{185}$ Krims, 8 Photographic Perspectives.

${ }^{186}$ Buffalo, NY: Humpy Press, 1972, 1975, 1980, respectively.

${ }^{187}$ The accompanying text in The Deerslayers states that the deluxe edition includes rifle targets, deerskin, an antler point, a hoof, "four 12 gauge deer slugs," a tape measure, and instructions for dressing a deer carcass. The Little People of America 1971 comes with a tape measure.

${ }^{188}$ Email from Les Krims to the author, April 12, 2013.

${ }^{189}$ Email to the author, April 11, 2013.

${ }^{190}$ In an email to the author, April 11, 2013, Krims mentioned portfolios to be called Roadside Deaths, The Ultimate Archival Print, Porsche Rainbows, and Piss Portraits, as well as an untitled edition of firework "set pieces," all of which were planned and carried out to varying preliminary degrees, but never completed. Idiosyncratic Pictures, referenced earlier, was however produced as a full deluxe edition in 1980.

${ }^{191}$ Krims, "An Unpublished, Unvarnished Interview."

${ }^{192}$ Email to the author, April 11, 2013.
} 
Much of Krims's career has been spent making work that comically but pointedly draws attention to what he sees as misguided or hypocritical attitudes in the photography world, or in society more generally. His work from the early 1970s in particular reflects both the exuberant experimentalism of the contemporary art world and the growing pains of the new photography market, along with its attendant expectations about what photography is or should be. Seen in this context, the three offset portfolios appear both emblematic of and anomalous to a historical moment, works that take their cues from the broader world of conceptual art, but whose particular concerns are distinctly photographic. Intentional or not, the relative commercial success of the small, offset versions of these portfolios (particularly in contrast to the original print versions) makes them especially astute as send-ups not only of the documentary traditions that Krims has spoken about directly, but of the portfolio format itself. By taking them out of their rarified niche by way of commercial printing and a large edition size, these portfolios turn a usually scarce luxury product into an effective vehicle for the very type of recognition that traditional portfolios have, at least since the twentieth century, aimed to achieve. At the same time, in contrast to the blatant opportunism and cursory production values of such projects as the Doubleday publications discussed earlier, Krims's portfolios remain fundamentally true to the spirit of his work. 


\section{Conclusion}

Despite the fact that it has most often been considered, when it has been considered at all, simply a physical format for housing and selling groups of photographs, the portfolio has had-and continues to have-a long, rich, and varied commercial and cultural history. Taking their cue from the traditional graphic arts and the established strategies of the print market, photographers have used the format to present groups of work both disparate and unified, and furthermore to enhance the expressiveness, coherence, and of course the salability of that work. As photography's role has developed from a scientific marvel and tool for memorializing the domestic sphere in the 1840s to a respected (and lucrative) art form today, with myriad additional uses along the way, the function, production, and meaning of the portfolio has shifted as well. A study of the portfolio therefore has much to impart about the proliferation of photography, and about changing perceptions of the medium, its value as documentation, and its status as art in particular. The fact that portfolios have been used continuously since at least the 1850s makes them especially articulate as indices of the impulse to collect, assemble, and circulate images, and of the evolving understanding of those practices.

As I have shown, there are a number of distinctive physical components and qualities that characterize photography portfolios in general, and inform how and why they are created and consumed. Beyond these commonalities, however, the range of portfolios that have been produced since the 1850s is enormous. The duc de Luynes's supplementary atlas of travel views and Edward Curtis's The North American Indian use portfolios to enrich ambitious geographic or ethnographic projects, for example. The sets of fine prints offered in the early- and mid-twentieth century by the likes of Ansel Adams and Brett Weston used them to promote the idea of photography as art, while in the multimedia experiments of the 1960s, 1970s, and through the present day, the format has been part of efforts to stretch the boundaries of the medium itself. Given the diversity and scope of its subject, the exploration presented in this thesis can thus be no more than exploratory, and there are a number of directions in which a further examination of the 
portfolio might be undertaken. At the most basic level, there remains to compile a working list, as comprehensive as possible, of photography portfolios produced since the format was introduced. The most cursory glance at Lee Witkin's chapter in The Photograph Collector's Guide reveals innumerable gaps, even within its self-imposed limitations (Witkin included only portfolios of gelatin silver prints, and of course the list necessarily ends in 1979, the year of its publication). The development of such a list would no doubt clarify a number of points on which one can only speculate at present, as well as reveal previously obscured patterns and thus open new avenues of exploration.

For the time being, I have attempted to provide a partial foundation for further study of the photography portfolio. By delineating a history, however skeletal; by outlining some of the characteristics that make portfolios distinctive; by suggesting ways that these have been informed by, and have contributed to, developments in photography more broadly; and by providing an analysis of a selection of representative case studies that, although limited, touch on some of what I consider the most central and absorbing aspects of the format, I have shown this to be a culturally and, in some instances, artistically significant form of presenting groups of photographs, and a timely and compelling subject for study. I believe that additional attention and elaboration would only enrich our understanding of this multifaceted and historically vital format. 


\section{BIBLIOGRAPHY}

The following bibliography is divided into eight sections, according to subject matter to allow the reader to more easily assess the resources used for the various sections of this thesis. The sections are as follows: 1) Photography Portfolios; 2) Photography Books, Seriality and Sequence, the Materiality of Photographs; 3) Photography of the 1960s and 1970s, Collecting Photography; 4) Paul Strand; 5) Ansel Adams; 6) Berenice Abbott and Eugène Atget; 7) Lee Friedlander and Jim Dine; and 8) Les Krims.

\section{Photography Portfolios}

Blodgett, Richard. "The Pros and Cons of Limited-Edition Portfolios." Photographs: A Collector's Guide, 121-124. New York: Ballantine Books, 1979.

Brown, Leslie K. Exhibition files, Out of the Box: Photography Portfolios from the Permanent Collection. DeCordova Sculpture Park and Museum, Lincoln, MA: October 2009-October 2010.

Chambers, Emma. "Objects of Desire: Etching and Print Collecting." An Indolent and Blundering Art?: The Etching Revival and the Redefinition of Etching in England, 63-87. Brookfield, VT: Ashgate, 1999.

Coleman, A. D. "Limited-Edition Photography Portfolios." Art on Paper 9, no. 3 (January/February 2005): 44-45.

Dewan, Janet. The Photographs of Linnaeus Tripe: A Catalogue Raisonné. Toronto: Art Gallery of Ontario, 2003.

Finley, Jeanne C. Exhibition files, The Portfolio as Object. The Center for Creative Photography, Tucson, AZ, June-August, 1981.

Gordon, Sophie. Cairo to Constantinople: Francis Bedford's photographs of the Middle East. Introduction by John McCarthy. London: Royal Collection, 2013.

Grundberg, Andy. Boxed Sets: Portfolios of the Seventies. Gallery walk, April 1, 2005. The Center for Creative Photography, Tucson, AZ: 2005. DVD.

Hamber, Anthony. "Facsimile, Scholarship, and Commerce: Aspects of the Photographically Illustrated Art Book (1839-1880)." In Art and the Early Photographic Album, edited by Stephen Bann, 124-149. Washington DC: National Gallery of Art, 2011.

Hirsch, Faye. "Multiple Configurations: Displaying the Contemporary Portfolio." Art on 
Paper 4, no. 1 (September-October 1999): 64.

Kennedy, Clarence. "Photographs in Portfolio." Magazine of Art (February, 1950): 68-69.

Newhall, Beaumont. "Collectors Turn to Photographs." New York Times, December 7, 1952.

--- and Van Deren Coke. "Editorial." Image 14, no. 3 (June 1971): 1.

Rice, Leland. New Portfolios. Claremont, CA: The Galleries of the Claremont Colleges, 1976.

Salvesen, Britt. "Boxed Sets: Portfolios of the Seventies." Curator's talk presented at the Center for Creative Photography, Tucson, AZ, March 10, 2005.

---. Wall text, Boxed Sets: Portfolios of the Seventies. The Center for Creative Photography, Tucson, AZ, March-May 2005.

Witkin, Lee D., and Barbara London. "Limited-Edition Portfolios." In The Photograph Collector's Guide, 276-99. Boston: New York Graphic Society, 1979.

2. Photography Books, Seriality and Sequence, the Materiality of Photographs

Balaschak, Chris. "Unstable Ground: Photography Books and the Modern Landscape, 1938-1975." PhD diss., University of California, Irvine, 2010. ProQuest (500017874).

---. "Between Sequence and Seriality: Landscape Photography and its Historiography in Anonyme Skulpturen." Photographies 3, no. 1 (April 2010): 23-47.

Carrion, Ulises. "Bookworks Revisited." Print Collector's Newsletter XI, no. 1 (March-April 1980): 6-9.

Castleberry, May. "The Presence of the Past." In Roth, The Book of 101 Books, 105-107.

Coleman, A. D. "Some Notes on the Photography Book." In Tarnished Silver: After the Photo Boom, 113-117. New York: Michmarch Arts Press, 1996. First published in 1981.

Dugan, Thomas. Photography Between Covers: Interviews with Photo-Bookmakers. Rochester, NY: Light Impressions, 1979.

---. "George Tice." In Dugan, Photography Between Covers, 149-167. 
Edwards, Elizabeth and Janice Hart, eds. Photographs Objects Histories. New York: Routledge, 2004.

Evans, Walker. "The Reappearance of Photography." Hound \& Horn V, no. 1 (OctoberDecember 1931): 25-128.

Freidus, Marc, James Lingwood, Rod Slemmons. Typologies: Nine Contemporary Photographers. Newport Beach, CA: Newport Harbor Art Museum, 1991.

Heath, Dave. Extempore. Michael Torosian, ed. Toronto: Lumiere Press, 1988.

Lyons, Nathan. "The Photographic Sequence." In Nathan Lyons: Selected Essays, Lectures, and Interviews, edited by Jessica McDonald, 195-199. Austin: University of Texas Press, 2012. First published in Camera Austria, no. 4 (1980): 75-79.

Parr, Martin, and Gerry Badger. The Photobook: A History. 2 vols. London: Phaidon, 2004-2008.

Rice, Shelley. "When Objects Dream." In Roth, The Book of 101 Books, 3-33.

Roth, Andrew, ed. The Book of 101 Books. New York: PPP Editions in association with Roth Horowitz LLC, 2001.

Sichel, Kim. "On Reading Photographic Books." Views 10, no. 4 /11, no. 1 (Summer/Fall 1989): 3 and 22.

Smith, Joel, "More than One: Sources of Serialism." In More than One: Photographs in Sequence, edited by Joel Smith, 9-29. Princeton, NJ: Princeton University Art Museum, 2008.

Trachtenberg, Alan. "Walker Evans's Message from the Interior: A Reading." October 11 (Winter, 1979): 5-29.

---. Reading American Photographs: Images as History, Mathew Brady to Walker Evans. New York: Hill and Wang; Toronto: Collins, 1989.

Tucker, Anne, ed. Target III, In Sequence: Photographic Sequences From the Target Collection of American Photography. Houston: Museum of Fine Arts, 1982.

3. Photography of the 1960s and 1970s, Collecting Photography

Badger, Gerry. Collecting Photography. London: Mitchell Beazley, 2003. 
Bunnell, Peter. Inside the Photograph: Writings on Twentieth-Century Photography. New York: Aperture Foundation, 2006.

---. "Helen Gee: Remembering the Limelight." In Inside the Photograph, 263-267. Originally published in Helen Gee and the Limelight: A Pioneering Photography Gallery of the Fifties, exhibition catalogue. New York: Carlton Gallery, 1977.

---. "The Witkin Gallery." In Inside the Photograph, 268-274. Originally published in The Witkin Gallery 25: A Celebration of Twenty-Five Years of Photography in New York City. Toronto: Lumiere Press, 1994.

---. "Light Gallery." In Inside the Photograph, 275-277. Exhibition wall text from $A$ Celebration of 25 Years of Light Gallery. New York: International Center of Photography Midtown, 1996.

Coleman, A. D. "Photography as Material Culture: A Primer for Collectors." Art on Paper 4, no. 1 (September-October 1999): 49-53.

---. "Photography as Material Culture: Originality at a Premium." Art on Paper 4, no. 4 (March-April 2000): 42-56.

---. "Photography as Material Culture: What are the Vintage Years?" Art on Paper 5, no. 2 (November-December 2000): 56-60.

Dennis, Landt and Lisl. Collecting Photographs: A Guide to the New Art Boom. New York: E. P. Dutton, 1977.

Grundberg, Andy. On and Off the Wall: Photography as Art in the 1970s and Since. Slide lecture and gallery walk, March 30, 2005. The Center for Creative Photography, Tucson, AZ: 2005. DVD.

Mackta, Jessica Lyn. "The Witkin Gallery, 1969-1979: A Critical Reading of the Paradigm of Photographic Display." Master's thesis, University of Arizona, 1997.

Mora, Gilles. The Last Photographic Heroes: American Photographers of the Sixties and Seventies. New York: Abrams, 2007.

"Photographs \& Professionals: Same Time, Five Years." Print Collector's Newsletter IX, no. 3 (July-August 1978): 78-86.

Quasha, Jill. "The Emergence of Photography as a Business: An Important 'New' Collectible." MBA thesis, New York University, 1980. 
---, Penelope Dixon, Harry Lunn, and Anne Tucker. "The Same Image-Dramatically Different Print Prices-Why?" The Photograph Collector XIV, no. 1 (January 15, 1993), 1-4.

Warner, Glen. Building a Print Collection: A Guide to Buying Original Prints and Photographs. Toronto: Van Nostrand Reinhold, 1981. Second edition: Toronto: Key Porter, 1984.

Warren, Beth Gates. "Market View: Photography's Second Decade." On Paper 1, no. 1 (1996): 22-25.

\section{Paul Strand}

Alexander, William. "Paul Strand as Filmmaker, 1933-1942." In Stange, Paul Strand: Essays on His Life and Work, 148-160.

Benson, Richard. "Print Making." In Stange, Paul Strand: Essays on His Life and Work, 103-108.

Krippner, James. Paul Strand in Mexico. México, D.F.: Fundación Televisa; New York: Aperture Foundation: Distributed by D.A.P., 2010.

---. "Traces, Images and Fictions: Paul Strand in Mexico, 1932-34." The Americas 63, no. 3 (January 2007): 359-383.

Lyons, Nathan. "From an Unpublished Interview with Paul Strand, 1965." In Nathan Lyons: Selected Essays, Lectures, and Interviews, edited by Jessica McDonald, 118121. Austin: University of Texas Press, 2012.

Rosenblum, Naomi. "The Early Years." In Stange, Paul Strand: Essays on His Life and Work, 31-51.

--- and Michael Torosian. Orgeval: A Remembrance of Paul Strand. Toronto: Lumiere Press, 1990.

Stange, Maren, ed. Paul Strand: Essays on His Life and Work. New York: Aperture, 1990.

Strand, Paul. Paul Strand: The Limited Edition Prints. New York: Aperture Foundation, n.d. [1981?].

Tompkins, Calvin. "Profile." In Paul Strand: Sixty Years of Photographs: Excerpts From His Correspondence, Interviews, and Other Documents, 15-35. Millerton, NY: Aperture, 1976. 
Trachtenberg, Alan. "Introduction." In Stange, Paul Strand: Essays on His Life and Work, $1-17$.

Tucker, Anne. "Strand as Mentor." In Stange, Paul Strand: Essays on His Life and Work, 122-135.

Ware, Katherine. "Photographs of Mexico, 1940." In Stange, Paul Strand: Essays on His Life and Work, 109-121.

---. "Photographs of Mexico, 1940." In Krippner, Paul Strand in Mexico, 267-273.

Weaver, Mike. "Dynamic Realist." In Stange, Paul Strand: Essays on His Life and Work, 197-207.

Mellquist, Jerome. "Paul Strand's Portfolio." The New Republic (November 4, 1940): 637-638.

\section{$\underline{\text { 5. Ansel Adams }}$}

Adams, Ansel. The Portfolios of Ansel Adams. Introduction by John Szarkowski. Boston: Little, Brown, 1977.

--- and Ruth Teiser. Conversations with Ansel Adams: Oral History Transcript / 1972-1975. Berkeley, CA: University of California, 1978. http://archive.org/details/convanseladams00adamrich.

Alinder, James, ed. Ansel Adams, 1902-1984. Carmel, CA: Friends of Photography, 1984.

Cooper, Tom, and Paul Hill. "Interview: Ansel Adams." Camera 55, no. 1 (1976): 15, 21, $27,37-40$.

Christie, Manson \& Woods International, Inc. Photographs by Ansel Adams From a California Collection. New York: Christie's, April 11, 2008.

Paul Strand and Ansel Adams: Native Land and Natural Scene. Text by Mike Weaver and Anne Hammond; Tucson, AZ: Center for Creative Photography, University of Arizona, 1990.

Stillman, Andrea Gray. Looking at Ansel Adams: The Photographs and the Man. New York: Little, Brown, 2012.

Through Their Own Eyes: The Personal Portfolios of Edward Weston and Ansel Adams. 
Introduction by Richard Andrews. Seattle, WA: Henry Art Gallery, University of Washington, 1991.

\section{$\underline{\text { 6. Berenice Abbott and Eugène Atget }}$}

Abbott, Berenice. The World of Atget. New York: Horizon Press, 1964.

---. "Eugène Atget." In Photography: Essays \& Images, edited by Beaumont Newhall, 23437. New York: Museum of Modern Art, 1980. Previously published in Creative Art 5 (September 1929): 651-56.

Atget, Eugène. Atget: Photographe de Paris. Preface by Pierre Mac-Orlan. Paris: Henri Jonquières, 1930. Translated by Robert Erich Wolf (New York : Errata Editions, 2008). Additional essay by David Campany.

Barberie, Peter. Looking at Atget. Philadelphia: Philadelphia Museum of Art, 2005.

Gee, Helen. Limelight: a Greenwich Village Photography Gallery and Coffeehouse in the Fifties. Albuquerque: University of New Mexico Press, 1997.

Hambourg, Maria Morris. "A Biography of Eugène Atget." In Szarkowski and Hambourg, The Art of Old Paris, 9-41.

---. "Eugène Atget, 1857-1927: The Structure of the Work." PhD diss., Columbia University, 1980.

---. "The Structure of the Work." In Szarkowski and Hambourg, The Ancien Regime, 9-33.

Harris, David. Eugène Atget: Unknown Paris. New York: New Press, 2003.

Hill, Paul and Thomas Cooper. "Man Ray" (interview). In Dialogue with Photography, 1725. New York: Farrar, Straus, and Giroux, 1979.

O’Neal, Hank. Berenice Abbott, American Photographer. New York: McGraw-Hill, 1982.

Solomon-Godeau, Abigail. "Canon Fodder: Authoring Eugène Atget." In Photography at the Dock: Essays on Photographic History, Institutions, and Practices, 28-51. Minneapolis: University of Minnesota Press, 1991. Previously published in Print Collector's Newsletter 17, no. 2 (January-February 1986): 221-27.

Szarkowski, John. "Understandings of Atget." In Szarkowski and Hambourg, Modern Times, 9-33. 
Szarkowski, John, and Maria Morris Hambourg. Old France. Vol. 1 of The Work of Atget. New York: Museum of Modern Art, 1981.

---. The Art of Old Paris. Vol. 2 of The Work of Atget. New York: Museum of Modern Art, 1982.

---. The Ancien Regime. Vol. 3 of The Work of Atget. New York: Museum of Modern Art, 1983.

---. Modern Times. Vol. 4 of The Work of Atget. New York: Museum of Modern Art, 1985.

Vestal, David and Muriel Rukeyser. Berenice Abbott Photographs. Washington: Smithsonian Institution Press, 1990.

Ware, Katherine. "Between Dadaism and MoMA-ism." In Dreaming in Black and White: Photography at the Julien Levy Gallery, Katherine Ware and Peter Barberie, 13121. Philadelphia: Philadelphia Museum of Art, 2006.

White, Minor. "Eugène Atget, 1856-1927." Image 5, no. 4 (April 1956): 76-83.

---. "Atget, a portfolio." Image 6, no. 2 (February 1957): 46.

Worswick, Clark. Berenice Abbott, Eugène Atget. Santa Fe, NM: Arena Editions, 2002.

Yochelson, Bonnie. Changing New York. New York: New Press: Museum of the City of New York, 1997.

\section{$\underline{\text { 7. Lee Friedlander and Jim Dine }}$}

Allison, Sue. "Q\&A: Lee Friedlander." American Photographer 7, no. 3 (March 1984): 52 61.

Benson, Richard. "Working with Lee," in Galassi, Friedlander, 436-443.

Dine, Jim. Jim Dine: Photographs. Charles Demarais, curator. Cincinnati, OH: Contemporary Arts Center, 1998.

Finch, Christopher. "Jim Dine." London Magazine 6, no. 10 (January 1967): 51-56.

Friedlander, Lee, and Jim Dine. Work From the Same House: Photographs \& Etchings. London: Trigram Press, 1969. 
Galassi, Peter. Friedlander. New York: The Museum of Modern Art, 2005.

Grundberg, Andy. "Popular Culture, Pop Art." In Photography and Art: Interactions Since 1946, Andy Grundberg and Kathleen McCarthy Gauss, 81-89. Fort Lauderdale: Fort Lauderdale Museum of Art; Los Angeles: Los Angeles County Museum of Art; New York: Abbeville Press, 1987.

Hennessy, Susie. "A Conversation with Jim Dine." Art Journal 29, no. 3 (Spring 1980): $168-75$.

Hoyem, Andrew. "Working Together: Collaboration in the Book Arts." Visible Language 25, no. 2/3 (Spring 1991): 197-216.

Kao, Deborah Martin. "Lee Friedlander's Factory Valleys: Structure, Artifice, Culture." Views 10, no. 4/11, no. 1 (Summer/Fall 1989): 10-13.

Renato, Danese and John R. Gossage. 14 American Photographers. Baltimore: Baltimore Museum of Art, 1974.

Russell, John. "Jim Dine and the Idea of the Print." London Magazine 10, no. 2 (May 1970): 46-55.

Slemmons, Rod. Like a One-Eyed Cat: Photographs by Lee Friedlander 1956-1987. New York: Harry N. Abrams, Inc., 1989.

\section{$\underline{\text { 8. Les Krims }}$}

Barrett, Terry. "The Offset Work of Les Krims: An Interpretive Critique." Camera Lucida 5 (Winter 1982): 49-57.

Coleman, A. D. The Grotesque in Photography. NY: Summit Books, 1977.

---. Light Readings: A Photography Critic's Writings, 1968-1978. Albuquerque: University of New Mexico Press, 1998.

---. "The Directorial Mode: Notes Toward a Definition." In Coleman, Light Readings, 246257. Originally published in Artforum (September 1976).

---. "Les Krims: Four Photographs That Drove a Man to Crime." In Coleman, Light Readings, 58-60. Originally published in New York Times (April 11, 1971).

---. "Violated Instants': Lucas Samaras and Les Krims." In Coleman, Light Readings, 238-242. Originally published in Camera 35 (July 1976). 
Frampton, Hollis. On the Camera Arts and Consecutive Matters: The Writings of Hollis Frampton. Cambridge, MA: MIT Press, 2009.

---. "Fictcryptokrimsographology." In Frampton, Camera Arts, 95-99. Originally published as the introduction to Fictcryptokrimsographs: A Book-Work by Les Krims (Buffalo, NY: Humpy Press, 1975).

---. "Pictures, Krims's Pictures, PLEASE!" In Frampton, Camera Arts, 100-102.

Krims, Les. "An Unpublished, Unvarnished Interview with a Conservative Artist," on the website of Les Krims. Copyright 2006, accessed February 16, 2013. http://www.leskrims.com.

---. "Can I Take Your Picture?' Interview with Les Krims." Afterimage I, no. 4 (November 1972): $2-4$.

---. "Les Krims." 8 Photographic Perspectives: A Lecture Series on Photography. Ryerson University, Toronto, October 13, 1977. CD.

---. "Les Krims: The Photographic Maverick." By Christian J. Peterson. Société Perrier, November 6, 2011. https://societeperrier.com/articles/les-krims-thephotographic-maverick/.

---. "Leslie Krims: Portfolio." Camera Mainichi, no. 8 (August 1970): unnumbered introduction page and 9-16.

Lyons, Nathan. "Les Krims," In Nathan Lyons: Selected Essays, Lectures, and Interviews, edited by Jessica McDonald, 190-194. Austin: University of Texas Press, 2012. First given as a lecture from the series Capturing the Vision: The Intrepid Photographer, Smithsonian Institution, Washington, D.C. (February 12, 1976).

Noël, Bernard. Les Krims. Arles (Bouches-du-Rhône): Actes Sud, 2005. 